\title{
The Furongian to Lower Ordovician Alum Shale Formation in conventional and unconventional petroleum systems in the Baltic Basin - A review
}

\author{
Hans-Martin Schulz ${ }^{1}$, Shengyu Yang ${ }^{2}$, Niels H. Schovsbo ${ }^{3}$, Erik Rybacki ${ }^{4}$, Amin Ghanizadeh ${ }^{5}$, \\ Sylvain Bernard ${ }^{6}$, Nicolaj Mahlstedt ${ }^{7}$, Martin Krüger $^{8}$, Alexandra Amann-Hildebrandt ${ }^{9}$, Bernhard \\ M. Krooss ${ }^{10}$, Tobias Meier ${ }^{11}$ and Andreas Reinicke ${ }^{12}$
}

\footnotetext{
${ }^{1}$ Helmholtz Centre Potsdam-GFZ German Research Centre for Geosciences, Sec. 3.2 Organic Geochemistry, D-14473 Potsdam, Germany; schulzhm@gfz-potsdam.de

${ }^{2}$ China University of Petroleum (East China), Qingdao, ChinaChina; s.yang@upc.edu.cn

${ }^{3}$ Geological Survey of Denmark and Greenland (GEUS), Øster Voldgade 10, DK-1350 Copenhagen K, Denmark; nsc@geus.dk

${ }^{4}$ Helmholtz Centre Potsdam-GFZ German Research Centre for Geosciences, Sec. 4.2 Geomechanics and Rheology, D-14473 Potsdam, Germany; erik.rybacki@gfz-potsdam.de

${ }^{5}$ Department of Geoscience, University of Calgary, 2500 University Dr. NW, Calgary, Alberta, Canada, T2N 1N4; aghaniza@ucalgary.ca

${ }^{6}$ Muséum National d'Histoire Naturelle, Institut de Minéralogie, Physique des Matériaux et Cosmochimie, CNRS UMR 7590, Sorbonne Université, CNRS, F-75005 Paris, France; sylvain.bernard@mnhn.fr

${ }^{7}$ Helmholtz Centre Potsdam-GFZ German Research Centre for Geosciences, Sec. 3.2 Organic Geochemistry, D-14473 Potsdam, Germany; nicolaj.mahlstedt@gfz-potsdam.de

${ }^{8}$ Department of Microbiology, Federal Institute for Geosciences and Natural Resources (BGR), Stilleweg 2, D-30655 Hannover; Martin.Krueger@bgr.de

${ }^{9}$ Institute of Geology and Geochemistry of Petroleum and Coal, RWTH Aachen University, Lochnerstrasse 4-20, D52056 Aachen, Germany; alexandra.amann@emr.rwth-aachen.de

${ }^{10}$ Institute of Geology and Geochemistry of Petroleum and Coal, RWTH Aachen University, Lochnerstrasse 4-20, D52056 Aachen, Germany; bernhard.krooss@emr.rwth-aachen.de

${ }^{11}$ Geomecon GmbH, Chausseestraße 88, 10115 Berlin, Deutschland; solutions @ geomecon.de

12 Nagra - Nationale Genossenschaft für die Lagerung radioaktiver Abfälle, Hardstrasse 73, CH-5430 Wettingen, Suisse, andreas.reinicke@nagra.ch
}

Key words: Black shale, Cambrian, Ordovician, organic carbon, petroleum, uranium 


\section{Abstract}

The organic carbon- and uranium-rich, marine Alum Shale Formation Formation in northwestern Europe (Middle Cambrian, Miaolingian to Early Ordovician) was deposited in the Baltic Basin and surrounding areas. It is a proven source rock for conventional oil either in sandstones of Cambrian age or Ordovician and Silurian carbonates, and also contains a potential for shale oil and for biogenic or thermogenic shale gas.

Despite the absence of higher land plant precursors, the primary Type II kerogen has an abnormally strong aromatic character, even at low thermal maturities due to $\alpha$-particle bombardment by the elevated uranium content. The characteristic aromatic kerogen structure results in dead carbon formation and enhances hydrocarbon retention. As a consequence, effective petroleum expulsion is limited during maturation.

The petroleum generation properties of the Alum Shale Formation changed over geological time due to the accumulated uranium irradiation. For thermally immature samples, high uranium content is positively correlated with high gas-oil ratios and the aromaticities of both the free hydrocarbons residing in the rock and the pyrolysis products from its kerogen. Such characteristics indicate that irradiation has had a strong influence on the overall organic matter composition and hence on the petroleum potential. At high uranium content, macromolecules are less alkylated than their less irradiated counterparts and oxygen containing-compounds are enriched. However, the kerogen structure was less altered during catagenesis (420-340 Ma bp) than at present, and thus calibration is needed to predict petroleum generation in time and space. In southern central Sweden biogenic methane in the Alum Shale Formation was formed during oil degradation after the Quaternary glaciation following bitumen impregnation generated from local magmatic Carboniferous - Permian intrusions. Consequently, the Alum Shale Formation includes a mixed shale oil/biogenic gas play that resembles the formation of biogenic methane in the Antrim Shale (Michigan Basin, United States). In the Alum Shale Formation, pore waters with low TDS content created a subsurface aqueous environment, which was favourable for microbes that have the potential to form biogenic methane. The ability to generate biogenic methane from samples of the Alum Shale Formation in incubation experiments still exists today.

The permeability coefficients of highly mature Alum Shale Formation from Bornholm island (southern Baltic Sea) cover a broad range from sub-nanodarcy to microdarcy, depending on permeating fluid type, moisture content, anisotropy, mean pore pressure and effective stress conditions. As a result, the primary high total organic carbon content was not significantly reduced at overmature stages, consistently with the high sorption capacities. The Alum Shale Formation is thus an attractive gas shale candidate from the perspective of gas generation and retention.

The strength of the overmature Alum Shale Formation on Bornholm, which is mainly determined by mineral composition, porosity and spatial distribution of the constituents, is relatively low 
compared to other well-studied shale formations. Based on brittleness estimates, the Alum Shale Formation may be regarded as an unconventional reservoir rock of medium quality from the mechanical point of view.

\section{Introduction}

The Alum Shale Formation Formation in northwestern Europe (Fig. 1) was deposited from the Middle Cambrian (Miaolingian) to the Early Ordovician (Tremadoc) in the Baltic Basin and surrounding countries (Nielsen and Schovsbo, 2006). Due to its high total organic carbon (TOC) content, widespread occurrence and varying maturity, it is a well-known conventional source rock for hydrocarbons found in Cambrian sandstones (Schleicher et al., 1998) and Ordovician and Silurian carbonates in the Baltic Basin (Sivhed et al., 2004, Yang et al., 2018). Also, these black shales raised attention for its atypical, i.e., gas generation characteristics (Bharati et al., 1992; Horsfield et al., 1992). More recent increased interest in unconventional shale plays also renewed attention on the Alum Shale Formation, which was found to be prospective for both thermogenic (Schovsbo et al., 2011; Pool et al., 2012) and biogenic gas (Schulz et al., 2015).

Besides being typically rich in TOC, the Alum Shale Formation is also enriched in uranium (Andersson et al., 1985) (Fig. 2), and has served for decades as a natural key laboratory for the investigation of organic matter changes due to the irradiation by $\alpha$-particles released from the decay of ${ }^{238} U$ (recently re-visited by Yang et al., 2019). The Alum Shale Formation was also a commercial source for uranium, which was produced between 1953 and 1984 with the final closure of the facilities in 1989 (Andersson et al., 1985; Dyni, 2006). Besides uranium, the rocks also host significant amounts of molybdenum, vanadium and nickel (Fig. 2).

After deposition, the Alum Shale Formation underwent laterally variable burial in the Baltic Basin and its surroundings resulting in various gradients. The (i) thickness ranges from millimeters to more than 100 meters, (ii) the burial depth is from zero to more than $3 \mathrm{~km}$, (iii) the thermal maturities range from immature conditions above the oil window to late gas generation, and (iv) TOC and uranium contents increase towards the top of the Cambrian interval (Buchardt et al., 1997; Pedersen et al., 2007; Schovsbo, 2001, 2002, 2003). This setting makes this stratigraphic unit a suitable natural laboratory for research about different factors which influence petroleum formation. Moreover, it was deposited prior to the development of land plants (it contains no vitrinite macerals). An important geological event occurred during the last ice age when the area was covered by glaciers with local ice thicknesses of more than $2 \mathrm{~km}$. This young geological history enables further studies of pore water mixing, biodegradation or elemental leaching, and needs to be taken into account for studies about, e.g., biogenic methane formation.Here we summarize the results of the latest research related to the petroleum potential of the Alum Shale Formation. First, we highlight the unique nature of the Alum Shale Formation kerogen and its depositional setting. Second, we discuss a broad variety of petroleum potential characteristics 
(aromaticity, gas-oil ratio, etc.) and processes which are dependent on time and space (expulsion, sorption, etc.) and also on uranium content. Finally, we introduce petrophysical properties that resulted from the complex geological history and that are of interest for unconventional hydrocarbon extraction.

\section{Methods and data}

This review article is based on published data from general geological (palaeogeography, sedimentology, tectonics) and petroleum related studies. The methods behind are described in detail in articles which are referred to in the text and given in the reference chapter.

The conceptual approach of this review article -and the basic idea for writing- is the combination with results from (i) recently published and yet unpublished data from the multidisciplinary "Gas Shales in Europe" (GASH) project (2009-2012), and (ii) recent work about the influence of uranium on the organic matter in the Alum Shale Formation. The interdisciplinary scientific GASH initiative investigated the Alum Shale Formation in Denmark and Sweden. Within the framework of GASH the shallow borehole Skelbro-2 on Bornholm island (Fig. 3) was drilled in 2010 through the Alum Shale Formation and fully cored (Schovsbo et al., 2011). The $35 \mathrm{~m}$ thick Alum Shale Formation on Bornholm is highly mature, and the reflectance of 'vitrinite-like' particles is about $2.3 \% \mathrm{VR}_{\mathrm{eq}}$. In addition to these overmature samples, additional immature and mature samples from boreholes and outcrops on the island of Öland and from southern Sweden completed the sample set.

The results of the GASH project are presented in chapter 6. "The Alum Shale Formation as an unconventional shale play", and here the analytical methods are described which were applied to the cores recovered from well Skelbro-2 and the additional sample material.

The measurements of basic data such as vitrinite reflectance $\left(\% \mathrm{VR}_{\mathrm{eq}}\right)$ or Total Organic Carbon (TOC) content were carried out according standard techniques.

In chapter 6.1.3. "Today's biogenic methane potential" the results of incubation experiments and gas analyses are presented. To test the sensitivity of five selected samples from the Alum Shale Formation from well Hällekis-1 (Fig. 3; VR eq $0.49 \%$ ) still be a source of microbially generated methane, different sets of incubations were carried out using ground core material and three different hydrocarbon-degrading methanogenic enrichment cultures as inocula: "Inoculum coal", "Inoculum oil", and "Inoculum hexadecane". In parallel, incubations were run without inoculum, containing only sample and medium, to check for microorganisms already present in the samples. The experiments run over six months, and methane and $\mathrm{CO}_{2}$ concentrations as well as their stable isotopic composition were measured by GC-FID and GC-C-IRM-MS. Details of the experimental methods and results are given in Krüger et al. (2014).

For micro-structural investigations (chapter 6.2.1), following Bernard et al. (2010), ultrathin foils of samples $\left(\sim 15 \times 5 \times 0.10 \mu \mathrm{m}^{3}\right)$ were prepared for scanning transmission X-ray microscopy 
(STXM) and transmission electron microscopy (TEM) investigations using the focused ion beam (FIB) single beam instrument (FEI FIB 200 TEM) operating at GFZ Potsdam. Milling at low gallium ion currents allowed minimising common artefacts including local gallium implantation, mixing of components, redeposition of the sputtered material on the sample surface and significant changes in the speciation of carbon-based polymers (Bernard et al., 2009). STXM investigations were conducted on the FIB foils to document both the distribution of organic compounds using the 10ID-1 STXM beamline at the Canadian Light Source (Kaznatcheev and Hegmann, 2007). X-ray absorption near edge structure (XANES) hypercube data (stacks) were collected with a spatial resolution of $25 \mathrm{~nm}$ at energy increments of $0.1 \mathrm{eV}$ over the carbon absorption range (275-350 eV) with a dwell time of less than $1 \mathrm{~ms}$ per pixel to prevent irradiation damage (Wang et al., 2009). Stack alignments and extraction of XANES spectra were done using the aXis2000 software, while normalisation of XANES data was done using the QUANTORXS freeware (Le Guillou et al., 2018). TEM investigations were conducted using the $200 \mathrm{kV}$ TECNAI F20 XTWIN TEM operating at GFZ Potsdam, equipped with a field emission gun as the electron source, a Gatan TridiemTM energy filter, an EDAX GenesisTM X-ray analyzer and a Fishione high angle annular dark filed detector (HAADF) allowing an image acquisition in the scanning transmission electron microscopy (STEM) mode. Energy dispersive X-ray spectroscopy (EDXS) element maps are displayed as background subtracted intensity maps.

In chapter 6.2.2. "Organic matter as source and reservoir (gas storage capacity)" the results of various experiments are presented. Rock-Eval pyrolysis parameter (S1, S2, S3, HI, OI, PI, T $\mathrm{T}_{\max }$ ) were determined using a Rock-Eval 6 instrument. All procedures followed NIGOGA, 4th edition. Thermovaporisation (Tvap) and Open-system pyrolysis (GC-FID) were performed using a Quantum MSSV-2 Thermal Analyzer@ interfaced with an Agilent GC 6890A gas chromatograph as described in Han et al. (2015). To determine bulk kinetics the rock samples were analysed by non-isothermal open-system pyrolysis at four different laboratory heating rates $(0.7,2.0,5.0$ and $15 \mathrm{~K} / \mathrm{min}$ ) using a Source Rock Analyzer(C). The generated bulk petroleum formation curves served as input for the bulk kinetic model consisting of an activation energy distribution and a single frequency factor. To gain results from the PhaseKinetics approach, compositional information from closed-system pyrolysis was combined with various open-system pyrolysis results to yield a compositional kinetic model which allowed the prediction of petroleum physical properties under subsurface conditions (di Primio and Horsfield, 2006). For closed-system pyrolysis milligram quantities sample material were sealed in glass capillaries (micro scale sealed vessels - MSSV, described in Horsfield et al., 1989) and, using an external prep-oven, artificially matured at $0.7 \mathrm{~K} / \mathrm{min}$ to temperatures required to bring about different levels of kerogen conversion (transformation ratios 10, 30, 50, 70, 90\% TR). The tubes were then cracked open using a piston device coupled with the injector using the Quantum MSSV-2 Thermal Analysis System $\odot$. 
In chapter 6.2.3. "Fluid transport properties (stress-dependent gas and liquid [water] permeability)" are presented. The helium porosity values were determined under unconfined conditions using the skeletal volumes measured by helium pycnometry and the bulk volumes calculated from the calipered dimensions. Single-phase gas $\left(\mathrm{He}, \mathrm{Ar}, \mathrm{CH}_{4}\right)$ and liquid (de-ionized water) flow tests were performed under controlled axial and confining pressures on cylindrical core plugs assembled in a customized fluid flow cell. The details of the customized fluid flow cell are explained elsewhere (Hildenbrand et al., 2006). Single-phase gas flow tests were conducted using steady-state (atmospheric downstream pressure) and non-steady-state techniques. Singlephase water flow tests were conducted under steady-state conditions by applying a constant pressure difference across the sample (atmospheric downstream pressure) and measuring the volumetric flow rate at the downstream using a graduated pipette (volume: $1 \mathrm{ml}$, graduation: 0.01 $\mathrm{ml}$ ). A leakage test with helium was performed prior to each flow test to ensure a leakagefree/tolerant system. A formulation which is based on the interpretation of the fundamental flow equations, i.e. the mass balance equation (continuity equation) and Darcy's law was used for evaluation of the non-steady-state gas permeability coefficients. Steady-state gas and liquid permeability coefficients were evaluated using the Darcy law for compressible (with slip-flow correction) and incompressible media, respectively. The details of the experimental set-up, procedures, and data evaluation are explained elsewhere (Ghanizadeh et al., 2014).

In chapter 6.2.4."Key petrophysical and geomechanical properties" are described. These data resulted from uniaxial compression experiments (UCS) and Brazilian disc tests which were performed using a servo-hydraulically controlled deformation apparatus (MTS). UCS tests and some triaxial deformation tests were performed at room temperature and confining pressures between 17 and $70 \mathrm{MPa}$ on samples of $50 \mathrm{~mm}$ length and $25 \mathrm{~mm}$ diameter at constant axial strain rate of $\approx 7 \times 10-5 \mathrm{~s}-1$. The tensile strength (TS) was determined on selected samples of $30 \mathrm{~mm}$ diameter and length $>15 \mathrm{~mm}$ following the ISRM suggested method for Brazilian disc testing (Bieniawski and Hawkes, 1978). Triaxial deformation experiments at elevated pressure and temperature of $\mathrm{P}=50 \mathrm{MPa}$ and $\mathrm{T}=100^{\circ} \mathrm{C}$ were done on cylindrical samples of $20 \mathrm{~mm}$ length and $10 \mathrm{~mm}$ diameter using a Paterson-type gas deformation apparatus (Paterson, 1970) at constant strain rate of 5x10-4 s-1. Measured forces and axial displacements were converted to axial stress and strain, assuming constant volume deformation and corrected for the jacket load and system compliance. The estimated error in stress and strain is $<4 \%$. The estimated uncertainties of determined Young's moduli E are about 20\%, determined from the slope of stress-strain curves from the origin to the strain measured at $50 \%$ of the peak stress. Details of the experimental methods and results are given by Rybacki et al. (2015).

\section{Geology}

\subsection{Palaeogeography}


The Baltoscandian Alum Shale Formation (Nielsen and Schovsbo, 2006) is a black organic-rich shale with up to 25 wt.\% TOC (Fig. 2) that was deposited from Middle Cambrian (Miaolingian) to Lower Ordovician (Tremadocian) on the Baltic plate (Fig. 4). The deposition was coupled with an overall transgression of the palaeocontinent Baltica within an original depositional area that covered more than $800,000 \mathrm{~km}^{2}$ and tracked several $1,000 \mathrm{~s} \mathrm{~km}$ from along the Norwegian/Swedish Caledonides in the North to Northwest to Poland in the South and further eastwards to Estonia and the St. Petersburg area in Russia (Fig. 1). Within this area, the shale exhibits a remarkable uniform lithology. Correlative sediments are named Türisalu Formation in Estonia, Kaporye Formation in the St. Petersburg region, and Stowinski or Piasnica Formation in Poland. The distinction of these naming reflects political rather than geological boundaries (Nielsen and Schovsbo, 2006). We hereafter refer to all these formations as the Alum Shale Formation.

\subsection{Sedimentology and thickness of the Alum Shale Formation}

The Alum Shale Formation consists of laminated to massive mudstone (Fig. 5A) with high amounts of organic matter and pyrite (Pedersen, 1989; Hints et al., 2014, Egenhoff et al., 2015, Henningsen et al., 2018). In more than $~ 10$ m thick intervals of the Alum Shale Formation, barite is common and occurs as layers or concretions of various size (Fig. 5A, B). A fairly simple differentiation of the shale into a mid-shelf and an outer-shelf facies (termed platform and shelf facies, respectively; Buchardt et al., 1997) has been proposed based on the abundance of carbonate concretions and intercalations of sandstone layers (e.g., Fig. 5E; Schovsbo, 2003; Nielsen and Schovsbo, 2006). In the upper Cambrian (Furongian; Fig. 4A) the mid-shelf was characterised by high abundance of limestone and carbonate concretions that constitute $>30 \%$ of the formation thickness. The carbonate beds probably reflect a preferential removal of fine-grained siliciclastics by currents (e.g., Dworatzek, 1987). The Tremadoc rocks (Fig. 4B) differ from the Furongian sediments by having a low proportion of carbonate concretion. The interpretation of the depositional energy at the seafloor has been based on the presence or absence of coarse-grained intercalations in the shale. In Estonia and Russia, a gradual transition towards the south and east can be seen from sandy intercalations in the shale to shaly intercalations in the sandstone (Hints et al., 2014; Schulz et al., 2019). In Estonia, particularly thick sections of this facies have been included in the Kallavere Formation that represents the transitional beds between the Furongian and the lowermost Tremadoc (Mens et al., 1993).

The thickness of the Alum Shale Formation varies considerably across Baltoscandia (Fig. 6). In south-central Sweden it is an incomplete section 20-25 m thick (Fig. 5E), whereas in Scania (the southernmost province of Sweden) and the central Oslo area in Norway it varies between 80 and $100 \mathrm{~m}$, and records more complete stratigraphy. The thickest section $(178 \mathrm{~m})$ has been encountered in the Danish offshore well Terne-1 (Figs. 3, 6; Schovsbo et al., 2016). The Alum 
Shale Formation thins towards the southern margin of Baltica where it measures only some 27$35 \mathrm{~m}$ on Bornholm (Nielsen et al., 2018), and $32 \mathrm{~m}$ in the offshore German well G-14 (Piske and Neumann, 1990). In Poland, Estonia, and Russia the Alum Shale Formation is thin and generally less than 10 m (Mens et al., 1993; Fig. 6).

The Alum Shale Formation contains a low-diversity, but abundant benthic to pelagic trilobite fauna in the Cambrian and a pelagic graptolite fauna in the Ordovician. This fossil assemblage has facilitated the definition of a high-resolution biostratigraphic zonation comprising three Miaolingian superzones subdivided into eight zones, six Furongian superzones subdivided into 26 zones and three Ordovician zones (Nielsen and Schovsbo, 2006; Nielsen et al., 2011, 2015). The base of the Alum Shale Formation is transgressive and diachronous being oldest in the depositional centres in the Kattegat and Scania and younger towards the basin margins. In Estonian and Russia, the basal parts of the Alum Shale Formation are of Tremadocian age.

Besides a high TOC content, the Alum Shale Formation exhibits a variety of trace elements, notably uranium, vanadium and molybdenum (Fig. 2; Armands 1972; Andersson et al., 1985; Schovsbo, 2002; Hints et al., 2014; Schovsbo et al., 2018). The enrichment in these redoxsensitive metals shows both a strongly stereographical pattern (enrichment towards the top) as well as a relation to the geographical location in the basin (enrichment along the former margins).

\subsection{Geological history after deposition of the Alum Shale Formation}

The tectonic evolution of the Tornquist Zone and adjacent sedimentary basins in Scania and the southern Baltic Sea were analysed by Erlström et al. (1997). This regional study focussed on southernmost Sweden, Bornholm and the surrounding Baltic Sea region. This area is hosted on a large-scale releasing bend in the dextral strike-slip system of the Tornquist Zone, with its resulting pull-apart basins.

Following deposition of the Alum Shale Formation, open marine depositional environments prevailed resulting in the accumulation of 1-3 km thick shale sequences of Ordovician-Silurian age. A change into coarse-grained siliciclastic sedimentation ("Old Red Sandstone") occurred during the late Silurian to Devonian as a result of uplift and Caledonian thrusting to the south. Devonian strata are not preserved north of the Caledonian Deformation Front (CDF) whereas they approach a thickness of approximately $3 \mathrm{~km}$ in the Rügen area (Fig. 1). During the late Palaeozoic (Carboniferous and Permian) continental conditions prevailed over much of the area. Sediments are locally preserved in pull-apart basins, e.g., in the Rønne Graben with approximately $350 \mathrm{~m}$ thick Permian sediments with indications of basaltic lava flows and dolerite dykes (Jensen and Hamann, 1989; Vejbæk et al. 1994). Block faulting during Triassic-Jurassic times resulted in lateral thickness and lithological variations of shallow marine-lacustrine deposits. The thicknesses of Triassic and Jurassic sediments can vary from $10 \mathrm{~m}$ to $2 \mathrm{~km}$ in pull-apart basins.

During the Early Cretaceous 100-150 m thick proximal deltaic sediments were deposited along 
the southwestern margin of the Tornquist Zone. During the latest Cretaceous, wide-spread proximal marine depositions prevailed over the southern part of the Baltic Shield, resulting in 800-2,000 m thick strata. Regression during the Cenozoic allowed the deposition of carbonate sediment followed by fine-grained siliciclastics $(100 \mathrm{~m})$. However, the Late Cretaceous and Cenozoic strata were eroded due to uplift of the southwestern margin of the Baltic Shield during the Neogene. This interplay between subsidence-related sedimentation vs. uplift-controlled erosion led to the current maturity pattern of the Alum Shale Formation (Fig. 6).

The origin of the present depression of the Baltic Sea is still controversial (erosion vs. tectonic processes). The Baltic Sea area was covered by ice sheets during several Quaternary glaciations. The last glaciation ended in the early Holocene, and -initially sourced by glacier meltwaterdeveloped to the current Baltic Sea with its connection to the North Sea (over the Kattegat and the Skagerrak; Fig. 1).

\subsection{Immature organic matter and early diagenesis}

The Alum Shale Formation Formation lacks input by embryophyte land plants, which first occurred in the mid-Ordovician. Thus the organic matter is marine and of algal and bacterial (and graptolite) origin (Petersen et al., 2013; Sanei et al. 2014; Figs. 7A, B). The TOC content of the Alum Shale Formation ranges from 2 to 25 wt.\% depending on the stratigraphic level (Buchardt et al., 1997; Schovsbo, 2001, 2002). Specifically, the TOC content in the Miaolingian interval increases upward to the Furongian, where it peaks in the Olenus and Peltura zones, and again declines in the uppermost Cambrian and Tremadocian (e.g., Schovsbo, 2001; Fig. 2).

Although the organic matter in the Alum Shale Formation is about 500 m.y. old, it is still thermally immature in wide areas of the Baltic Sea region (Fig. 6). The high TOC content results from bottom water anoxia and low sediment accumulation rates (Schovsbo, 2001). It is important to note that sulfate reduction and following methanogenesis consumed the labile organic matter; the TOC content during deposition was thus significantly higher than today's measurable content. Deposition of mud was accompanied by very limited clastic influx, probably mostly by aeolian transport (Schulz et al., 2019). Accordingly, the surface sediment layer during deposition may have been a soft layer consisting predominantly of organic matter, comparable to a biofilm.

Immature Alum Shale Formation samples offer insights into well-preserved processes of early diagenesis. The immature organic matter can be tight (Fig. 8A, B) or highly porous (due to uranium irradiation; Fig. $8 \mathrm{C}$ ), and concentrated in layers or mixed in irregular arrangement with inorganic phases (Fig. 8C, D). Moreover, nanometer sized intercalations occur as phyllosilicate minerals (organo-mineral nanocomposites; Fig. 8A; acc. Kennedy et al., 2014), which may be an additional preservation factor for the organic matter besides bottom-water anoxia and/or biological productivity. However, the organic matter in the Alum Shale Formation is, if waterfilled fissures allow ion exchange, also the matrix for organic-inorganic interactions which have 
led to the precipitation of, for example, pyrite, brookite/anatase (Schulz et al., 2016), K-feldspar (Fig. 8B), or quartz (Fig. 8D).

\subsection{Thermal maturity}

In order to assess the thermal maturity, it is important to keep in mind that vitrinite particles sensu stricto are absent from the sedimentary record prior to the Mid-Ordovician. The thermal maturity of the Alum Shale Formation, similarly to most lower Palaeozoic shales, is instead evaluated based on the reflectance of graptolite or vitrinite-like particles $\left(\mathrm{VR}_{\mathrm{eq}}\right)$ that behave in a similar manner with respect to thermal maturation as real vitrinite (Buchardt and Lewan 1990; Petersen et al. 2013; Lou et al., 2020).

The Alum Shale Formation deposited on the southern and western fringes of Baltica became deeply buried in the Caledonian foreland (e.g., Buchardt and Lewan, 1990; Vejbæk et al., 1994; Buchardt et al., 1997; Samuelsson and Middleton, 1998; Pedersen et al., 2007; Poprawa et al., 2010 ) as seen by an increase in graptolite reflectance from about $0.5 \% \mathrm{VR}_{\mathrm{eq}}$ in central Sweden to $>2.6 \% \mathrm{VR}_{\mathrm{eq}}$ towards the CDF (Fig. 6). Peak burial is assumed to have occurred during the late Silurian to Devonian as rapid subsidence and high clastic input led to the accumulation of several kilometres of sediments in the Caledonian foreland basin in southern Scandinavia. One dimensional petroleum system basin modelling, based on eight boreholes throughout the western Baltic region, revealed that the Alum Shale Formation reached $0.5 \% \mathrm{VR}_{\mathrm{eq}}$ from Early Devonian throughout Early Cretaceous (Kosakowski et al., 2010).

\subsection{Conventional oil and gas in the Baltic Basin}

A considerable amount of oil and gas has been produced in the Baltic Basin both onshore and offshore. Prospecting for hydrocarbons in the Baltic area can be traced back to 1870s on the Swedish mainland (Sivhed et al., 2004), and major discoveries were achieved in 1970s when oil fields were announced in northern Poland and the former Soviet Union (today Kaliningrad Oblast; Kanev et al., 1994; Kotarba, 2010). By 2012, more than 700 wells had been drilled and about 50 small oilfields had been discovered in the Baltic states and Poland (Zdanaviciute et al., 2012). In 2015, new discoveries of oil fields were announced in this area (all fields are close to well D33 in Fig. 3). Among these fields, D33 contains recoverable oil reserves of around $155 \mathrm{MMbbl}$, making it the first mid-size field in the Baltic Basin (Otmas et al., 2018). Prior to these new discoveries, the U.S. Geological Survey estimated the undiscovered, technically recoverable

conventional hydrocarbon resources to be $39 \mathrm{MMbbl}$ of oil and 16 billion cubic meters of gas in the Baltic Basin (Brownfield et al., 2015).

In the onshore and offshore areas of Poland, Kaliningrad, and Lithuania as well as in the Latvian onshore area, a significant number of oil accumulations has been discovered, all occurring in Cambrian sandstone reservoirs (Kanev et al., 1994; Schleicher et al., 1998; Møller and Friis, 
1999). The most prolific reservoir rocks for hydrocarbon accumulations are Miaolingian Deimena Group sandstones (Fig. 9). Other major reservoirs include Ordovician carbonate reefs, mainly in Latvia and on the island of Gotland (Sweden), and Silurian reefs in the central part of Lithuania (Sivhed et al., 2004).

Petroleum within the Baltic Basin has moderate gravity values (26-42 ${ }^{\circ}$ API) which generally decrease with increasing reservoir depth (Zdanavičiūtè, 2004; Pedersen et al., 2007). Laterally, the hydrocarbon type roughly parallels the regional trend of thermal maturity, i.e., natural gas is typically found in Northern Poland and oil occurs to the north and east (cf. Fig. 6). In general, thermally mature oil, characterized by a pronounced dominance of light $n$-alkanes, and a virtual absence of sterane and terpane biomarker compounds is found in the southwestern parts of the basin, i.e. in Poland, Kaliningrad, and western Lithuania. The east-northeastern parts of the Baltic Basin, i.e. the Latvian and central Lithuanian onshore areas are characterized by less mature oil with less pronounced dominance of light $n$-alkanes, and a low content of steranes and terpanes (Kanev et al., 1994; Bojesen-Koefoed et al., 2001).

\section{The Alum Shale Formation as a conventional source rock}

Several lower Palaeozoic shales (Fig. 9) are potential source rock candidates for the conventional petroleum found in the Baltic Basin. The general consensus is that the principal source rock for the petroleum found in the Baltic Basin is a marine shale rich in algae (Zdanaviciute and BojesenKoefoed, 1997; Więcław et al., 2010). Accordingly, the Alum Shale Formation and the Llandovery shales with their wide occurrence, considerable thicknesses and high TOC content are considered as the most likely source rocks (e.g., Schleicher et al., 1998; Møller and Friis, 1999).

Extensive oil-source rock correlations based on biomarker analyses, stable carbon and hydrogen isotopes, and basin modelling have been carried out to identify the main source $\operatorname{rock}(\mathrm{s})$ (Kosakowski et al., 2010; Kotarba and Lewan, 2013; Zdanaviciute and Bojesen-Koefoed, 1997). However, the conclusions were controversial due to several reasons: (i) the lack of terrigenous input during the early Palaeozoic, (ii) the absence of the characteristic Gloecapsamorpha prisca fingerprint often observed in oils derived from Ordovician source rocks and their extracts (Douglas et al., 1991; Fowler, 1992), (iii) the lack of a potential carbonate source rock, and (iv), and most important, the majority of biomarkers was destroyed by irradiation in the uranium-rich Alum Shale Formation (see chapter 5).

There are several indications that the Alum Shale Formation is the major source rock for conventional oil and gas accumulations in the Baltic Basin. Based on stable carbon isotope data and hydrous pyrolysis experiments, Kotarba (2010) and Kotarba and Lewan (2013) concluded that the Upper Cambrian and Tremadocian Alum Shale Formation is the main contributor for the natural gas found in the Polish and Lithuanian sectors, and that the Llandovery shales are a minor 
source. Pedersen et al. (2007) suggested that -based on biomarkers- oil in the western Baltic Basin (northern Poland) was sourced from the Furongian-Lower Ordovician Alum Shale Formation, whereas Silurian shales are more likely the source rocks for the oil accumulations discovered in the eastern part (Latvia, Lithuania, and Kaliningrad). A recent biomarker study combined with data from principal component analyses revealed that most of the produced oil in the Baltic Basin can be traced back to the Alum Shale Formation rather than Llandovery shales when age and depositional environment-related biomarkers are considered (Fig. 10), although oil mixing from different source rocks is also possible in some cases (Yang et al., 2017).

The main Alum Shale Formation oil kitchen is in the southwestern part of the basin (Fig. 6), and thus oil discovered in the eastern part must have migrated over tens -if not hundreds-of kilometers if no minor kitchens exist nearby. Furthermore, data from basin modelling support long-distance migration over a relatively stable basement and within regional carrier beds (Wrobel and Kosakowski, 2010). Lateral migration is also supported by low asphaltene (Zdanaviciute and Lazauskiene, 2004) and low carbazole content in crude oil in Lithuania (Yang et al., 2017), which tend to fractionate during migration (Larter et al., 1996). Dahl et al. (1989) speculated that oil produced from Ordovician carbonates on the island of Gotland did not migrate over long distances, instead it was locally generated from the Alum Shale Formation as result of Carboniferous-Permian intrusions (Obst, 2000).

\section{The influence of uranium on the source rock potential}

\subsection{Uranium in the Alum Shale Formation}

Whereas sedimentary rocks in general have an average uranium content of four ppm (Swanson, 1961), the uranium concentrations of black shales are higher, averaging eight ppm for shales and 30 ppm for the organic-rich "hot shale" of Silurian age in the Middle East (Lüning et al., 2005). The uranium content in the Alum Shale Formation can be as high as 400 ppm (Schovsbo, 2002), and discrete organic-rich beds within Alum Shale Formation, known as "Kolm", contain concentrations of up to 8,000 ppm (Fig. 11; Schovsbo, 2002). The Alum Shale Formation holds the largest low-grade uranium resource in Europe (Merkel and Arab, 2015).

Uranium can be retained in the sediment under reducing depositional conditions (Goldschmidt, 1937), for it is soluble in oxic seawater and the solubility significantly decreases in reducing environments by reduction of U (VI) to U (IV) (Durand, 2003). Therefore, uranium precipitation from the aqueous phase requires both uranium-rich pore water and seawater under reducing conditions (Breger and Brown, 1962; Disnar and Sureau, 1990). In addition, uranium can be originally adsorbed on the surface of certain detrital minerals, e.g., apatite, zircon, or rutile, to be later re-deposited together with shale (Schulz et al., 2019). So far, three hypotheses have been proposed to explain the uranium enrichment in the Alum Shale Formation:

I. Berry et al. (1986) suggested that the interaction of submarine basaltic volcanic and 
hydrothermal activity with highly anoxic water in the Oslo Graben area during deposition of the Alum Shale Formation led to high uranium content. Local volcanic influence may explain why coeval shale units in Wales, North America, and South America contemporaneously deposited with the Alum Shale Formation lack comparable high uranium content.

II. A comparison with the Devonian Chattanooga Shale led Leventhal (1991) to conclude that the high uranium content in the Alum Shale Formation could be attributed simply to slow sedimentation rates coupled with long-lasting euxinic bottom water conditions which may have preserved both the organic matter and metals.

III. Schovsbo (2002) reported that the uranium content of the Alum Shale Formation is proportional to the layer thickness which implies that uranium was preferentially enriched in the inner-shelf area rather than in the outer-shelf facies. An intensified bottom water circulation may have resulted in an enhanced supply of uranium at the sediment/water interface where the uranium extraction from the seawater took place.

Recent investigations of "Kolm", a special facies or concretion in the Alum Shale Formation showed that uranium is exclusively bound or adsorbed on the mineral matrix rather than on the organic fraction (Yang et al., 2019).

\subsection{Uranium irradiation effect on organic matter in the Alum Shale Formation}

The most common isotopes of natural uranium are ${ }^{238} \mathrm{U}(99.27 \%)$ and ${ }^{235} \mathrm{U}(0.72 \%)$. With a halflife of 4.5 billion years, the natural decay of ${ }^{238} \mathrm{U}$ would mainly emit $\alpha$-particles followed by less intensive $\gamma$-particles (Jaraula et al., 2015). First considerations in the 1950s suggested that fatty acids can be decarboxylated by $\alpha$-particle radiation at $130{ }^{\circ} \mathrm{C}$ to form hydrocarbons (Sheppard and Burton, 1946). However, this early hypothesis neglected that most petroleum is formed by the thermal cracking of the insoluble kerogen (Abelson, 1963; Tissot and Welte, 1984). Since then, the irradiation effects on organic matter in sedimentary rock either soluble or insoluble were subject of detailed investigations, especially in the 90 s (see references in the next paragraph) about the Alum Shale Formation.

One major and obvious irradiation result is the low extractability of the organic matter in the Alum Shale Formation. This feature is due to high uranium content (Hoering and Navale, 1987) and caused by crosslinking effects induced by irradiation (Court et al., 2006). When the uranium content in immature Alum Shale Formation is higher than 150 ppm, only few aliphatic biomarkers can be detected and $\mathrm{C}_{26}-\mathrm{C}_{28}$ triaromatic steroid biomarkers in the aromatic fraction would disappear as well (Dahl et al., 1988b; Lewan and Buchardt, 1989). Such characteristic irradiationaltered biomarker distributions were successfully applied in oil-source rock correlations in the Baltic Basin (Yang et al., 2017). Irradiation may also impact isotopic signatures due to the preferential cracking of ${ }^{12} \mathrm{C}-{ }^{12} \mathrm{C}$ bonds rather than ${ }^{12} \mathrm{C}-{ }^{13} \mathrm{C}$ bonds. In general, the ${ }^{13} \mathrm{C} /{ }^{12} \mathrm{C}$ ratios correlate well with the log of the uranium concentration (Leventhal and Threlkeld, 1978), as 
confirmed for the Alum Shale Formation (Dahl et al., 1988a).

Irradiation over time affects the petroleum potential and prevents a correct assessment by means of standard pyrolysis methods or elemental analysis. For example, the atomic $\mathrm{H} / \mathrm{C}$ ratio of kerogen, which is used to define the kerogen type and thermal maturity, is negatively correlated with the uranium content in shale (Charlesby, 1954; Pierce et al., 1958). This is probably due to the release of hydrogen in response to irradiation (Colombo et al., 1964). Immature samples from Västergötland and Öland (see Fig. 1 for locations) with Hydrogen Indices (HI) averaging $450 \mathrm{mg}$ $\mathrm{HC} / \mathrm{g}$ TOC exhibit TOC values similar to those of overmature equivalents from Bornholm (5-12 wt.\% TOC in well Skelbro-2; see data in later Fig. 19) with depleted HI values below $20 \mathrm{mg} \mathrm{HC} / \mathrm{g}$ TOC. It is thus possible that first-formed products (soluble organic matter) were retained within the source rock matrix rather than expelled which finally led to the formation of dead carbon and late gas. Such an extreme "zero-expulsion" scenario might not be applicable to all depositional areas of the Alum Shale Formation. However, the inert carbon content increases with increasing maturity (Horsfield et al., 1992) and may also affect the TOC balance.

The irradiation-induced alteration of solid organic matter in the Alum Shale Formation is also reflected on a molecular level. Pyrolysates are characterized by significantly enhanced levels of gaseous and aromatic compounds compared to typical marine shales (Lewan and Buchardt, 1989; Horsfield et al., 1992). For example, not only overmature samples of the Alum Shale Formation (VR $\geq 2.0 \%$ in well Skelbro-2 and Gislövshammar outcrop; Fig. 3) generate a very short-chained, aromatic, and essentially sulphur-compound free pyrolysate, but already samples from the immature Alum Shale Formation (Fig. 12A, B). The open-system pyrolysate composition of samples from well Hällekis-1 (Fig. 3)in Västergötland fall, in contrast to samples from Öland with probably lower uranium contents, into the gas condensate field of the ternary diagram defining petroleum type organofacies (Horsfield, 1989; Fig. 12A) and into the high aromaticity Type III field of the ternary diagram defining aromaticity and especially sulphur-richness (Eglinton et al., 1990; Fig. 12B). The high content of aromatic compounds yielding alkyl structures dominated by cyclic/short-chains within the immature Alum Shale Formation kerogen likely result from the $\alpha$-particle bombardment induced by the ${ }^{238} \mathrm{U}$ decay. For instance, kerogen within strata deposited in an inner-shelf environment during the Upper Cambrian (Furongian; U $>100 \mathrm{ppm}$ ) releases petroleum with higher gas-oil ratios (GOR) and aromaticity than kerogen within strata deposited further offshore during the Middle Cambrian (Miaolingian; $U<<100$ ppm). A correlation based on a larger sample set showed that the uranium content generally correlates well with pyrolysate composition (Fig. 13) in that U-richer samples generate pyrolysates with higher GOR and higher aromatic compounds content (Yang et al., 2018). In the same publication Fourier Transform Ion Cyclotron Resonance mass spectrometry was used to evidence the alteration of the kerogen structure. The alkylation degree of the aromatic core 
structures decreases and the attached hydrocarbon chains shorten with increasing $\alpha$-particle bombardment.

Uranium irradiation can also potentially affect the timing of petroleum formation. Kinetic parameters for bulk petroleum generation of the Alum Shale Formation were determined within the GASH-project for one immature Middle Cambrian Alum Shale Formation sample using opensystem bulk pyrolysis ( $c f$. di Primio and Horsfield, 2006). The bulk reaction is described by a single frequency factor A of $9.43 \mathrm{E}^{+14}(1 / \mathrm{s})$ and an activation energy (Ea) distribution with the main Ea, accounting for $\sim 35 \%$ of the reaction, at $56 \mathrm{kcal} / \mathrm{mol}$ (Fig. 14). The kinetic parameters are higher than commonly assumed for oil and gas formation from marine, siliciclastic source rocks, i.e., compared to Type II model source rocks (51-54 kcal/mol; Braun and Burnham, 1992), the Lower Jurassic Posidonia Shale (52-54 kcal/mol; Dieckmann et al., 1998), or a series of samples from different facies (48-55 kcal/mol) investigated by di Primio and Horsfield (2006). Thus, organic matter within the Cambrian Alum Shale Formation seems to be slightly more stable than organic matter within many younger shales (Devonian to Mesozoic source rocks) which are not so rich in uranium. Assuming a $3{ }^{\circ} \mathrm{C} / \mathrm{My}$ heating rate, bulk petroleum generation can be expected for temperatures between $\sim 130^{\circ} \mathrm{C}(\mathrm{TR}=10 \%)$ and $170^{\circ} \mathrm{C}(\mathrm{TR}=90 \%)$, which is characteristic for stable marine, sulphur-poor OM (Tegelaar and Nobel, 1994; di Primio and Horsfield, 2006) and which is still on the lower temperature end of a larger Alum Shale Formation suite measured by Yang (2017). Upper Cambrian, U-richer samples (U>100ppm) show here an even higher onset temperature for petroleum generation (TR $=10 \%$ at $\sim 140^{\circ} \mathrm{C}$ ) than Middle Cambrian, U-poorer $(\mathrm{U}<50 \mathrm{ppm})$ samples. Hence, data on present-day pyrolysates of immature and uranium-rich Alum Shale Formation samples should be applied with caution in predicting petroleum type, composition, and physical properties. Uncertainties arise from uranium irradiation which is independent on both temperature and pressure, and which has been altering the organic matter in the Alum Shale Formation since deposition. The alteration processes include demethylation and cracking, and aromatization and crosslinking (e.g., Dahl et al., 1988a, b; Lewan and Buchardt, 1989; Court et al., 2006). In the main kitchen area of the basin trough, the Alum Shale Formation reached oil-window maturity relatively early ( 410-320 Ma), and the irradiation effect was less severe due to a shorter exposure time probably resulting in less gasprone and aromatic kerogen (Fig. 15). A back-calibration of the kerogen structure is mandatory to avoid over-estimations of gas generation and retention in the Alum Shale Formation.

Note that the uranium content of the Alum Shale Formation is not necessarily a reliable parameter in evaluating the cumulative irradiation. For example, the flushing of meltwater through the Dictyonema Shale (a shallow-water equivalent of the Alum Shale Formation) during the Pleistocene deglaciation has mobilized the uranium near St. Petersburg and decreased its concentration since then. The application of the present-day uranium content would thus underestimate irradiation effects (Schulz et al., 2019). 


\section{The Alum Shale Formation as an unconventional shale play}

The Alum Shale Formation Formation is of great interest for the exploration and exploitation of unconventional gas in southern Scandinavia, in particular Denmark and Sweden, and in northern Poland (Schovsbo et al., 2014, 2015, 2017; Lou et al., 2020). Exploration of shale plays in the region of interest started in 2008 targeting both biogenic methane and thermogenic gas.

Biogenic methane is a shale gas resource in southcentral Sweden (Schulz et al., 2015) and was explored by Gripen Gas between 2010-2016. Exploration of thermogenic shale gas focussed on the Skåne region in southern Sweden (Fig. 1) where the Alum Shale Formation has a thickness of more than $80 \mathrm{~m}$. Here the TOC values are up to $16 \mathrm{wt} . \%$ (7 wt.\% on average) and thermal maturities are up to $>2 \% \mathrm{VR}_{\mathrm{eq}}$ (compare Fig. 6). Total porosity average $6.5 \%$ and permeabilities $40 \mathrm{nD}$. The shales were found with only low gas saturation (30 scf/ton rock) compared to the possible total storage capacity of ca. $75 \mathrm{scf} /$ ton rock (Pool et al., 2012). The low gas saturation was explained by low gas-filled porosity due to high water saturation. Uplift after melting of greater than $3 \mathrm{~km}$ thick ice sheet during the Weichselian cold stage (Schwarzer et al., 2008) may have had an additional impact on gas desorption and leakage. Exploration activities spread to Denmark where significant thermogenic shale gas resources of $6.9 \mathrm{Tcf}$ are assumed in tilted fault blocks in Jylland (central Denmark) and on Sjælland (eastern Denmark; U.S. Geological Survey, 2013).

\subsection{Biogenic methane}

The formation of biogenic methane occurred during two phases in the geological history of the Alum Shale Formation: (i) during early diagenesis, and (ii) during oil degradation after the Quaternary glaciation. Today, (iii) immature organic matter in the rocks still has a potential for biogenic methane which was demonstrated in incubation experiments.

\subsubsection{Biogenic methane formation during early diagenesis}

Evidence for biogenic methane formation in the Alum Shale Formation is the occurrence of diagenetic barite which may precipitate at the sulfate-methane transition (SMT) zone in marine sediments. In old sediments it is thus an indicator that this reactive zone existed (e.g., Arndt et al., 2006; Henkel et al., 2012) and that biogenic methane formation took place in the basinal facies of the Alum Shale Formation (Fig. 5A, B).

In general, primary biogenic barite particles form in the water column with the degradation of organic matter (Dehairs et al., 1980; Bishop, 1988; Dymond et al., 1992; Francois et al., 1995). Dissolved sulfate needed for the precipitation of barite is removed by reduction into sulfide in the sediment column until an almost total disappearance in the SMT. Consequently, primarily formed barite particles become undersaturate below the SMT and dissolve. Released barium ions diffuse 
upwards into sulfate-enriched sediments and re-precipitate as diagenetic barite crystals in a distinct zone slightly above the SMT, where the presence of sulfate allows the precipitation of barite. The SMT during early diagenesis of the Alum Shale Formation may have developed in a similar way, and was thus an important redox-boundary, which indicates both the production of biogenic methane and its anaerobic oxidation. However, the location of the SMT and thus the periodic occurrence of barite layers and nodules in the Alum Shale Formation is determined by the sulfate-methane interplay. The interplay depends on a variety of processes including methane fluxes, the amount of the converted organic matter of the total sediment column, sedimentation rate, and the bottom water sulfate concentration (Arning et al., 2015). It is furthermore important to note that the shallow water depth of approximately tens of meters in the Alum Shale Formation Sea prevented biogenic methane with water to form gas hydrate.

\subsubsection{Biogenic methane formation during oil degradation after the Quaternary glaciation}

In Östergötland (Fig. 1), the lower part of the thermally immature Alum Shale Formation was impregnated by bitumen (Fig. 5F) locally generated by heating from Carboniferous-Permian magmatic intrusions (Dahl et al., 1989; Buchardt and Lewan, 1990). Organic geochemical data indicate that the migrated bitumen is slightly degraded (e.g., high unresolved complex mixture, UCM; Schulz et al., 2015). In the upper part of the Alum Shale Formation, where methane is the main hydrocarbon in thermovaporization experiments, centimeter-size calcite crystals occur that contain fluid inclusions filled with oil, gas, or water (Fig. 5C, D). Conceptually, the formation of biogenic methane was explained by conversion of water-soluble bitumen components to methane, and was retraced by a hydrogeochemical modelling approach (Schulz et al., 2015).

The Alum Shale Formation in southcentral Sweden is considered a mixed shale oil-biogenic shale gas play. The conceptual model to explain the methane occurrence in the Alum Shale Formation resembles the formation of biogenic methane in the Antrim Shale (Michigan Basin, United States; Martini et al., 1998, 2003). In both models, melting water after the Pleistocene glaciation and modern meteoric water may have diluted the content of total dissolved solids (TDS) in basinal brines (McIntosh et al., 2002, 2004), thereby creating a subsurface aqueous environment favourable for microbes to form biogenic methane (Formolo et al., 2008). A conceptual event chart summarizing the described processes is presented in Fig. 16.

\subsubsection{Today's biogenic methane potential}

To test the sensitivity of the Alum Shale Formation as a source of microbial methane (and carbon dioxide), different sets of incubation experiments were carried out with three different hydrocarbon-degrading enrichment cultures as inocula. The results of five immature Alum Shale Formation samples $\left(\mathrm{VR}_{\mathrm{eq}}\right.$ : $0.49 \% \mathrm{R}_{\mathrm{o}}$ ) are compared with Posidonia Shale samples (Lower Jurassic, Lower Saxony Basin, Germany), covering maturities from immature conditions through 
the oil window to dry gas generation. Here, we present published results (Krüger et al., 2014). Three types of methanogenic enrichment cultures were inoculated to separate the sets of incubations:

- Inoculum coal:

originated from coal samples of the Ruhr Basin (Krüger et al., 2008) and has been shown to be capable of degrading different types of coals to methane in vitro,

- Inoculum oil: originated from mud volcano sediments from Romania (Feisthauer et al., 2010),

- Inoculum hexadecane: an enrichment culture obtained from a freshwater ditch near

- Medium: Bremen (Feisthauer et al., 2010), and containing only sample and medium, to check for microorganisms already present in the samples.

In comparison with Posidonia Shale samples, the immature Alum Shale Formation samples exhibited a significantly higher average methanogenic potential. The methane production rates were up to $1 \mu \mathrm{mol} \mathrm{g} \mathrm{g}^{-1}$ TOC d $\mathrm{d}^{-1}$ (Fig. 17a, "Medium"). Accordingly, also higher carbon dioxide production (up to $4 \mu \mathrm{mol} \mathrm{g}{ }^{-1} \mathrm{TOC} \mathrm{d}^{-1}$ ) occurred in these experiments (Fig. 17b, "Medium"). Production rates of both $\mathrm{CH}_{4}$ and $\mathrm{CO}_{2}$ were faster in the inoculated microcosms and no significant differences among the inocula (obtained from oil, coal or $\mathrm{n}-\mathrm{C}_{16}$ degradation experiments) were observed in the $\mathrm{CO}_{2}$ production (with values highly varying, from 40 to $508 \mu \mathrm{mol} \mathrm{g}^{-1} \mathrm{TOC} \mathrm{d}^{-1}$ ). However, "inoculum n- $\mathrm{C}_{16}$ " could produce methane at higher rates (35 to $89 \mu \mathrm{mol} \mathrm{g}^{-1} \mathrm{TOC} \mathrm{d}^{-1}$ ) than the other two inocula ( 1 to $\left.13 \mu \mathrm{mol} \mathrm{g}^{-1} \mathrm{TOC} \mathrm{d}^{-1}\right)$.

\subsection{Thermogenic gas}

The shallow borehole Skelbro-2 was drilled through the Alum Shale Formation on Bornholm island in 2010. The Alum Shale Formation on Bornholm is highly mature, and the reflectance of 'vitrinite-like' particles is about $2.3 \% \mathrm{VR}_{\text {eq. }}$. The Skelbro-2 well cored the $4 \mathrm{~m}$ thick mid Ordovician Komstad Limestone before entering the Alum Shale Formation (Fig. 18). The well was terminated in the lower Cambrian Læså Formation at $42.9 \mathrm{~m}$. The geophysical logs have enabled a detailed logstratigraphical frame to be made (Fig. 18). The fully cored Alum Shale sequence is overall fairly homogeneous and composed of fine-grained mudstone with a low proportion of diagenetic carbonate beds and barite concretions (Fig. 5A, B). This type of Alum Shale has been termed the 'outer shelf' type. In the basal parts the shale contains the Andrarum and Exsulans limestone beds that serve as important regional marker beds. The highest TOC content occurs in the Furongian part of the shale where TOC ranges between 8-14\% (Fig. 19).

\subsubsection{Micro-structure}


Ultrathin focused ion beam (FIB) foils were extracted from three samples of the shallow borehole Skelbro-2 (see Fig. 19) for scanning transmission X-ray microscopy (STXM), X-ray absorption near edge structure (XANES) spectroscopy, and transmission electron microscopy (TEM) (Figs. 20, 21). The data reveal their highly heterogeneous nature at the submicrometer scale.

STXM images collected below the carbon absorption energy and STXM maps reveal that the organic matter occurs as micrometric patches more or less connected to each other, constituting the actual rock matrix (Fig. 20; to be compared with immature samples in Fig. 8). The organic fraction of the Alum Shale Formation samples appears quite homogeneous. A few (likely detritic) graphite particles were identified by the excitonic feature at $291.7 \mathrm{eV}$ in their XANES spectra, related to the presence of planar domains of highly conjugated $\pi$ systems (Fig. 20; Bernard et al., 2010a). All the other organic compounds of the three investigated Alum Shale Formation samples exhibit very similar C-XANES spectra. These spectra are characterized by (i) a very broad and intense absorption centered at $285.0 \mathrm{eV}$, related to the significant concentration of aromatic and olefinic carbons, and (ii) absorption features at 287.8 and $288.5 \mathrm{eV}$, related to the presence of heteroatoms (Fig. 20; Bernard et al., 2012a, b). Such spectra are typical of thermally altered overmature kerogen or pyrobitumen (Bernard and Horsfield, 2014).

The nanoporous appearance in the investigated samples (Fig. 20) may indicate their pyrobituminous nature. As demonstrated by detailed studies of maturation series, organic porosity develops in gas shale systems during increasing thermal maturation due to secondary cracking processes of bitumen (Bernard et al. 2012a, b; Curtis et al. 2012a, b; Loucks et al. 2012; Bernard and Horsfield, 2014). Yet, given the very high maturity of the Alum Shale Formation samples investigated here ( $\mathrm{VR}_{\mathrm{eq}}: 2.3 \% \mathrm{R}_{\mathrm{o}}$ ) and the absence of non-porous kerogen compounds to compare with, the possibility that this porosity results from variable volume changes during late conversion of kerogen cannot be excluded (Loucks et al. 2009, 2012). The exact nature of the organic compounds of the Alum Shale Formation samples investigated remains difficult to determine. In fact, the broad absorption feature related to the presence of aromatic and olefinic carbons is centered at $285 \mathrm{eV}$ rather than at $285.3 \mathrm{eV}$ as is generally the case for gas mature kerogen compounds rather than at $285.0 \mathrm{eV}$ as is the case here (Bernard et al., 2012a, b).

The mineral matrix of the samples is composed of micro- to submicrometric phases (Fig. 21). The main mineral component of these samples includes $\mathrm{Si}, \mathrm{Al}$ and $\mathrm{Mg}$ and can be confidently identified as Mg-rich clay minerals. Closely associated are $\mathrm{K}$ - and Ca-rich minerals also containing $\mathrm{Si}$ and $\mathrm{Al}$ and traces of $\mathrm{Mg}$. These phases are likely also clays, as suggested by their shape and composition (Fig. 21). Finally, a few K-rich and Fe-rich phases as well as quartz particles can be observed, either embedded within clays or within organic compounds. Altogether, this mineral assemblage is quite typical of gas shale systems (Bernard et al., 2012a, b; Han et al., 2017), besides the absence of mineral phases (e.g., albite) usually seen as tracers of hydrothermal brine circulation and previously described in other gas shale systems (Bernard and Horsfield, 


\subsubsection{Organic matter as source and reservoir (gas storage capacity)}

The TOC content of the overmature Alum Shale Formation in the Skelbro-2 well ranges from 5$12 \mathrm{wt} . \%$, and $\mathrm{T}_{\max }$ data of around $600{ }^{\circ} \mathrm{C}$ reflect the advanced kerogen conversion $\left(\mathrm{VR}_{\mathrm{eq}}: 2.3 \%\right.$ ) leading to $\mathrm{HI}$ values below $20 \mathrm{mg} \mathrm{HC} / \mathrm{g}$ TOC (Fig. 19). The TOC content of the immature Alum Shale Formation core samples from the Hällekis-1 well is similar, but due to immature conditions $\mathrm{HI}$ values average $450 \mathrm{mg} \mathrm{HC} / \mathrm{g}$ TOC and $\mathrm{T}_{\max }$ values $\sim 420^{\circ} \mathrm{C}$ (calculated $\mathrm{VR}_{\mathrm{eq}}$ of $\sim 0.4 \%$ ). The high residual TOC content in overmature samples is a unique characteristic of the uranium-rich Alum Shale Formation (Horsfield et al., 1992) and is caused by low expulsion efficiencies and the increase of inert carbon in kerogen with increasing maturity.

Analytical pyrolysis (Horsfield et al., 1992; Lewan and Buchardt, 1989; Yang et al., 2018) suggests a rather gassy petroleum composition throughout the classical oil window development, even for samples which were less affected due to lower uranium content. For example, the PhaseKinetics approach (di Primio and Horsfield, 2006) was applied for one immature, Middle Cambrian Alum Shale Formation sample. The results show that gas-oil ratio (GOR), saturation pressure (Psat) and formation volume factor (Bo) increase rapidly as a function of maturity as defined by transformation ratio (TR $10-90 \%$ ) from 63 to $210 \mathrm{Sm}^{3} / \mathrm{Sm}^{3}$, from 81 to 171 bar, and from 1.28 to $1.78 \mathrm{~m}^{3} / \mathrm{Sm}^{3}$, respectively (Fig. 22A). Black oil (GOR up to $160 \mathrm{Sm}^{3} / \mathrm{Sm}^{3}$, Psat up to $200 \mathrm{bar}$ ) is generated throughout primary kerogen conversion up to $70 \% \mathrm{TR}$, and volatile oil is generated in excess of $80 \% \mathrm{TR}$. The GOR increase with maturity is rather steep compared to many younger (Mesozoic), more aliphatic marine or lacustrine source rocks for which GORs usually remain below $100 \mathrm{Sm}^{3} / \mathrm{Sm}^{3}$ at comparable maturation levels (cf. di Primio and Horsfield, 2006). These atypical characteristics in the composition of pyrolysates can be related to the uranium irradiation effect (as the sample is thermally immature) and a back-calculation is necessary to assess the hydrocarbon generation characteristics during diagenesis. However, yet unknown precursors were also considered for these characteristics, alternatively or additionally, and argued as biopolymeric or carotenoid-derived precursors in algae and bacteria (Horsfield et al., 1992).

In line with those results, thermovaporisation(Tvap)-gas chromatographic fingerprints acquired during the GASH-project (e.g., Mahlstedt and Horsfield, 2019) reveal the occurrence of $n$-alkane envelopes in the low molecular weight range $\left(<n-C_{18}\right)$ for Alum Shale Formation samples of all maturities, which is an empirical prerequisite for high productivity according to Jarvie et al. (2007). Such envelopes usually occur at maturities $>1.4 \%$ VR and indicate that oil or bitumen within the shale reservoir is secondarily degraded to gas and thus no longer occludes pore throats causing rapidly declining production rates. Kerogen in the Alum Shale Formation was thus already initially cracked to a short-chain dominated, high GOR petroleum/bitumen, marking the 
Alum Shale Formation as an excellent gas shale candidate even at lower maturities compared to, e.g., the Mississippian Barnett Shale in the Fort Worth Basin (U.S.A.).

Not only the gas generation potential of the Alum Shale Formation is excellent, but also its gas sorption/storage capacity. Generally, sorption capacity increases with maturity, as a result of the increase in aromaticity of the residual organic matter (e.g., Gasparik et al., 2014a; Mahlstedt and Horsfield, 2019). Interestingly, on a per gram organic carbon basis the Alum Shale Formation exhibits higher sorption capacities at all maturities than the Lower Jurassic Posidonia Shale (North German Basin), presumably due to its overall higher organic matter aromaticity. This can be either inferred from TOC normalised $n_{L}$ values (Langmuir amount defining the maximum methane sorption capacity at infinite pressure; Gasparik et al., 2014a) or from S2 normalised thermovaporisation (Tvap) gas yields (Mahlstedt and Horsfield, 2019). For example, the immature Alum Shale Formation samples from Västergötland (well Hällekis-1 with $\mathrm{VR}_{\mathrm{eq}}$ of $\sim 0.49 \%$ ) exhibit similar or even higher sorption capacities than all Posidonia Shale samples including those from the most mature Haddessen well (VR $\sim 1.45 \%$; Fig. 23). The high gas retention capacity of the Alum Shale Formation is very likely related to the increased aromaticity of the kerogen structure which is induced by the uranium irradiation (Yang et al., 2018).

Mahlstedt and Horsfield (2019) have shown that vertical profiles of Tvap gas yields $\left(\mathrm{C}_{1-5}\right.$, actually an S0 equivalent) can be used as a screening tool for the assessment of gas-sorptive properties of shales (Fig. 19). Further applications are projections and calibrations of the adsorption capacities defined by using excess methane isotherms measured on single samples. Tvap data are actually not useful to replace established petrophysical procedures for determining correct and reproducible adsorption isotherms as other geological factors, which influence the gas in place, in turn offer chances for a more detailed investigation. For example, comparatively low Tvap gas yields were observed in well Skelbro-2 especially in the vicinity of water flow zones (lower part of the profile; Fig. 19). This indicates loss of gas caused by high water saturations within the pore space of the rock and directly confirming previous observations ( $\sim 80 \%$ water saturation; Pool et al., 2012). The Alum Shale Formation was found with only low gas saturation (30 scf/ton rock) compared to the possible total storage capacity of ca. 75 scf/ton rock (Pool et al., 2012). In line with this, production index (PI) values for any of the investigated Alum Shale Formation samples (GASH) are lower than the minimum 0.7 value for high prospectivity (Jarvie et al., 2007). Nevertheless, gas loss during sample handling and storage until analysis may also have caused low PI values.

The marine Alum Shale Formation is very unique in petroleum generation and retention, the TOC content of highly mature shale is still high, the pyrolysates are dominated by light and aromatic compounds, and the gas retention capacity is exceptionally high. These unique characteristics are all related to the uranium decay-induced $\alpha$-particle bombardment, but should also be critically scrutinized as possibly inherited signals from precursors, especially in uranium-poor intervals. 


\subsubsection{Fluid transport properties (stress-dependent gas and liquid [water] permeability)}

Despite significant resource estimates for unconventional gas plays such as the Alum Shale Formation, production forecasting still remains a challenge due to regional tectonic elements and/or sedimentological heterogeneities (e.g., intercalation of sand layers, carbonate concretions, etc.). During hydrocarbon production from shales, fluid transport processes occur at multiple scales in space (e.g., matrix vs. fracture) and time (flowback, long-term production, etc.). These transport phenomena mostly occur simultaneously, and are difficult to separate into distinct flow regimes. These flow mechanisms comprise (i) the non-Darcy regime with significant inertial effects, mainly in hydraulic fracture networks, (ii) Darcy flow (pressure-driven viscous flow) within micro-fractures and larger macropores (pore width $>50 \mathrm{~nm}$; see Thommes et al., 2015 for pore classification), (iii) non-Darcy slip flow in smaller macropores and mesopores (pore width between 2 and $50 \mathrm{~nm}$ ), and (iv) molecular transport with desorption/diffusion in micropores (pore width $<2$ nm; e.g., Ghanizadeh et al., 2014). Matrix permeability of organic-rich shales is further controlled by pore network characteristics (e.g., pore [and pore throat] size distribution, pore connectivity/tortuosity, etc.), fluid type and composition, reservoir pressure/temperature, effective stress and capillary processes (e.g., Amann-Hildenbrand et al., 2012).

Up to now, only a few studies have examined the fluid flow characteristics of the Alum Shale Formation experimentally. Laboratory-based quantification of matrix permeability, in particular, has been the subject of only two previous studies (Pool et al., 2012; Ghanizadeh et al., 2014). Analysing a selected sample suite of the fully mature Alum Shale Formation from southern Sweden ( $\left.>1.7 \% \mathrm{VR}_{\mathrm{eq}}\right)$, Pool et al. (2012) reported an average matrix permeability coefficient of about $40 \mathrm{nD}\left(4 \cdot 10^{-20} \mathrm{~m}^{2}\right)$. The experimental conditions under which the permeability coefficients were measured including the type of permeating fluid(s) and mean pore pressure(s) were not, however, specified in detail.

Within the frame of the GASH project, Ghanizadeh et al. (2014) investigated the fluid (gas/water) transport characteristics in the matrix system of the Alum Shale Formation in the shallow Skelbro2 well under variable pore pressure and effective stress conditions. The analysed diverse core plug sample suite differed in TOC content (2.4 - 8.2 wt.\%), thermal maturity (VReq $0.5-2.4 \%$ ), mineralogy (clay-rich vs. quartz-rich), orientation (i.e. parallel/perpendicular to bedding), and moisture content (dried vs. "as-received"). The latter study documented that the permeability coefficients of the Alum Shale Formation cover a broad range from sub-nanodarcy to microdarcy, depending on fluid type, moisture content, anisotropy, mean pore pressure and effective stress conditions.

Based on these experimental results, the slip flow-corrected gas (He) permeability coefficients (measured at effective stress of $30 \mathrm{MPa}$ ) increased consistently with increasing porosity (2.5$13.7 \%$, determined by helium expansion) from $14 \mathrm{nD}\left(1.4 \cdot 10^{-20} \mathrm{~m}^{2}\right)$ to $4.5 \mu \mathrm{D}\left(4.5 \cdot 10^{-18} \mathrm{~m}^{2}\right)$. 
Further, the slip flow-corrected gas $\left(\mathrm{He}, \mathrm{Ar}, \mathrm{CH}_{4}\right)$ and water permeability coefficients decreased in the order $\mathrm{He}>\mathrm{Ar}>\mathrm{CH}_{4}>$ water under similar experimental conditions. This observation is in agreement with the results of previous studies reported for coals (Massarotto, 2002; Han et al., 2010; Adeboye and Bustin, 2013; Gensterblum et al., 2014) and other organic-rich shales (e.g., Sinha et al., 2013). Using sister core plugs, the slip flow-corrected gas $\left(\mathrm{He}, \mathrm{CH}_{4}\right)$ permeability coefficients measured on a dried $\left(110^{\circ} \mathrm{C}\right.$, vacuum overnight) core plug (total helium porosity: 8.9 $\%)$ were up to six times higher than those measured on "as-received" core plug (water-filled helium porosity: $5.7 \%$; Fig. 24) under similar effective stress conditions. The effect of "in-situ" fluids on gas $\left(\mathrm{He}, \mathrm{CH}_{4}\right)$ permeability coefficients was found to become more significant with increasing effective stress. The slip flow-corrected gas (He) permeability coefficients measured parallel to bedding (horizontal core plugs) were up to one order of magnitude higher than those measured perpendicular to bedding (vertical core plugs). In general, permeability anisotropy in organic-rich shales is caused by heterogeneities such as laminations, the presence of interbeds, and the preferred orientation of platy minerals (such as mica and clay flakes). Moreover, parallel and perpendicular to bedding, a nonlinear reduction in permeability (described by an exponential relationship; Fig. 25) was observed with increasing effective stress. The quantification of the stress-dependence of permeability is important for the modelling of fluid flow processes and the evolution of production in unconventional gas reservoirs.

\subsubsection{Key petrophysical and geomechanical properties}

The knowledge of mechanical properties is essential for assessing the potential of a given shale gas play for economic and sustainable gas extraction from boreholes and for determining prospectivity. High strength and brittleness are preferred properties for successful reservoir stimulation by hydraulic fracturing and are preferentially coupled to an extended pre-existing natural fracture network, sufficient borehole stability, and low closure rates of (propped) artificial fractures. In practise, empirical correlations between petrophysical, geomechanical, mineralogical and geochemical parameters are often established to assess the shale gas prospectivity (e.g., Horsrud, 2001; Chang et al., 2006; Eseme et al., 2007; Sone and Zoback, 2013; Rybacki et al., 2015).

Here, we present results of petrophysical and geomechanical measurements on Alum Shale Formation core samples from the shallow Skelbro-2 well. The experimental methods are described in chapter 2. Methods and data. Further details of the experimental setup and results are given by Rybacki et al. (2015). To our best knowledge, these are the only publicly available geomechanical data of the Alum Shale Formation.

\subsubsection{Density, porosity and composition}

Measurements of density and p-wave velocity of core samples collected at $\approx 17$ to $41 \mathrm{~m}$ depth 
(Fig. 19) were carried out on-site immediately after coring. The average bulk density ( $\rho$ B-OS) was $2.48 \pm 0.09 \mathrm{gcm}^{-3}$ and the average grain density ( $\rho \mathrm{G}-\mathrm{OS}$ ) was $2.62 \pm 0.09 \mathrm{gcm}^{-3}$, determined on site by drying of fresh samples until zero weight-loss. The associated average water content (WOS) was on average $3.6 \pm 0.5 \mathrm{wt} . \%$, which yields an average porosity (ФOS) of $8.9 \pm 1.1 \mathrm{vol} \%$ of the Alum Shale Formation samples (see gray arrows for key petrophysical properties in Fig. 19). The mean $\Phi O S$ is quite similar to the total (average) connected porosity $(\Phi \mathrm{He}=10.3 \pm 1.5 \%)$ measured by He-pycnometry (Micromeritics AccuPyc 1340), but considerably lower than the connected (average) porosity ( $\Phi \mathrm{MIP}=2.4 \pm 1.1 \%$ ) obtained by mercury injection porosimetry (MIP, Porotec Fisons 120+2000WS). The results indicate that the majority of pores are micropores $(<2 \mathrm{~nm}$ size), which cannot be captured by mercury injection.

$\mathrm{X}$-ray diffraction analysis of selected samples showed that the investigated fine-grain component (grain size $<10 \mu \mathrm{m}$ ) in the Alum Shale Formation is mainly composed of clay minerals, quartz, kerogen and pyrite. Carbonates are present only as a minor phase. The composition of the investigated shale samples is presented in a ternary diagram that contains the approximate fraction of mechanically strong $(\mathrm{QFP}=$ quartz + feldspar + pyrite $)$, weak $(\mathrm{CTMP}=$ clays $+\mathrm{TOC}+$ micas + pores) and carbonate $(\mathrm{Cb})$ constituents for each shale formation (Fig. 26). Carbonates are moderately strong, in particular at atmospheric conditions. Compared to other black shales (Fig. 26), the investigated carbonate-poor Alum Shale Formation samples contain a high fraction of mechanically weak phases.

\subsubsection{Sonic velocity attributes}

The average P-wave velocity ( $\left.\mathrm{V}_{\mathrm{P}-\mathrm{OS}}\right)$ of fresh Alum Shale samples determined parallel to bedding was $2.9 \pm 0.1 \mathrm{kms}^{-1}$, which is close to the mean sonic velocity $\left(\mathrm{V}_{\mathrm{P}-\log }=3.2 \pm 0.6 \mathrm{kms}^{-1}\right)$ obtained from sonic logging. To estimate the anisotropy of ultrasonic P-wave velocities, measurements were additionally performed in axial direction perpendicular to bedding (parallel to the core axis) and in lateral direction parallel to bedding (perpendicular to the axis) in $30^{\circ}$ intervals. The mean maximum $\left(\mathrm{V}_{\mathrm{P}-\text { lat-max }}\right)$ and minimum $\left(\mathrm{V}_{\text {P-lat-min }}\right)$ lateral velocities were $3.4 \pm 0.1 \mathrm{kms}^{-1}$ and $3.0 \pm 0.5$ $\mathrm{kms}^{-1}$, respectively, whereas the axial velocity $\left(\mathrm{V}_{\mathrm{P} \text {-axial }}\right)$ was distinctly higher $\left(4.3 \pm 0.3 \mathrm{kms}^{-1}\right)$. The corresponding azimuthal anisotropy, defined by the difference between maximum and minimum lateral velocity, normalized to their mean value, is about $12 \%$ and the total anisotropy, defined by the difference between minimum lateral and axial velocity, normalized to their mean value, is about $37 \%$.

\subsubsection{Geomechanical properties}

Strength and static Young's modulus of recovered rocks were measured on "as-received" (containing $\approx 3.6$ wt. $\% \mathrm{H}_{2} \mathrm{O}$ ) specimens parallel to bedding, unless specified. The unconfined 
tensile strength (TS) varied between 4.0 and $10.2 \mathrm{MPa}$ with an average value of TS $=7.2 \pm 1.8$ $\mathrm{MPa}(27$ tests). TS was about six times lower than the mean uniaxial compressive strength UCS of $54.7 \pm 32.7 \mathrm{MPa}$ (15 tests, range: 13.0 - 106.8 MPa). Both parameters do not show any clear correlation with mineral composition, porosity, or maturity. Measured values of the Young's modulus (E), determined by the secant method at $50 \%$ of the peak stress, were in the range of 6.0 $-31.7 \mathrm{GPa}$ with an average value $\left(\mathrm{E}_{\mathrm{uni}}\right)$ of $16.3 \pm 8.7 \mathrm{GPa}$. Comparison of the results reveal that the measured UCS and $\mathrm{E}_{\text {uni }}$ data show a positive linear correlation and both increase with increasing sonic velocity VP-log (Rybacki et al., 2015). Therefore, sonic logs may be used to estimate UCS from these empirical (site-specific) correlations, which is important to assess the risk of borehole breakouts, even in anisotropic shales (Meier et al., 2013, 2015).

At ambient conditions, the shale often reacts to deform in a brittle manner, usually expressed by the linear Mohr-Coulomb failure criterion in terms of cohesion and internal friction coefficient $(\mu i)$. This parameter is of interest for "in-situ" strength and borehole stability estimates. The internal friction coefficient of the Alum Shale Formation, determined on three sample sets in the stress range of $17-70 \mathrm{MPa}$, is between 0.36 and 0.55 , typical for many black shales. The coefficient tends to decrease with increasing proportion of weak phases and decreasing maturity. Considering other shale formations, $\mu \mathrm{i}$ appears to increase with increasing content of strong minerals (e.g., quartz, feldspar, pyrite) above a fraction of about 30 vol.\%, which is presumably associated with the formation of a load-bearing framework (Rybacki et al., 2015).The evaluation of mechanical properties was also performed at elevated $\mathrm{P}$ and $\mathrm{T}$ conditions, simulating the boundary conditions at about 2-4 km depth, the common depth of most drilling and stimulation operations in shale formations. An example of stress-strain curves measured on "as-received" samples at $\mathrm{P}=50 \mathrm{MPa}$ and $\mathrm{T}=100{ }^{\circ} \mathrm{C}$ is shown in Fig. 27. For bedding-parallel (p) loading, the triaxial compressive strength (TCS) of Alum Shale Formation is about 4 times higher under triaxial compared to UCS measured at uniaxial (ambient) conditions. For bedding-normal (n) deformation, the Young's modulus $\left(\mathrm{E}_{\text {tri }}\right)$ is somewhat lower than measured parallel ( $\mathrm{p}$ ) to bedding, as expected from easy deformation of the weak layers and closing of bedding-parallel microcracks. Beside fabric anisotropy, the strength also depends on water content. TCS increases by about $30 \%$ if samples are dry, whereas TCS decreases by about the same amount at water saturation (Rybacki et al., 2015). The latter observations are in agreement with those of Ghanizadeh et al (2014), who investigated the stress-dependent permeability of Alum Shale Formation samples under dried and "as-received" conditions (Fig. 24).

The mechanical behaviour of Alum Shale Formation at the applied conditions is close to those of the Posidonia and Haynesville shales (Fig. 27). In contrast Bowland, Barnett and Marcellus shales are clearly stronger and more brittle, owing to their different mineral composition, porosity and spatial distribution of the constituents. Although the triaxial compressive strength and Young's modulus do not correlate well with the amount of strong or weak phases for a single formation 
(Rybacki et al., 2015), TCS and $\mathrm{E}_{\text {tri }}$ decrease with increasing amount of weak constituents if different shale formations are compared and if their fraction is less than 25-30 vol.\% (Herrmann et al., 2018). In many cases, both parameters can be roughly approximated from the whole rock composition by the generalized mixture rule (Rybacki et al., 2015).

A parameter frequently used in the oil and gas industry to characterize the mechanical behaviour of shale is the brittleness index $\mathrm{B}$, which is often normalized to values ranging between 0 (ductile) and 1 (brittle). Unfortunately, no unique definition of the brittleness $\mathrm{B}$ exists and it was determined in many different ways that are not all physically meaningful (Rybacki et al., 2016; Zhang et al., 2016). Interestingly, at low P-T conditions prevailing to about $4 \mathrm{~km}$ depth, the brittleness of shales derived from the (pre-failure) stress strain behaviour can be approximated from their composition or Young's modulus, which allows using core or sonic logs for first order estimates (Rybacki et al., 2016). Such brittleness estimates also correlate with the long-term deformation behaviour of shale, which may contribute to the typically-observed production rate decline over time (Rybacki et al., 2017). The brittleness of the Alum Shale Formation at $\mathrm{P}=50$ $\mathrm{MPa}$ and $\mathrm{T}=100{ }^{\circ} \mathrm{C}$ is about $\mathrm{B}=0.2-0.4$, higher than that of the Posidonia Shale, but distinctly lower than that of the Bowland and Barnett shales (Rybacki et al., 2016; Herrmann et al., 2018). Many black shales deform in a semibrittle manner under reservoir conditions, i.e., the strong (QFP) minerals deform by brittle deformation processes that are pressure dependent whereas the weak components (clays, mica, kerogen) deform more plastically, for which the deformation mechanisms are temperature and strain rate dependent. However, for shale formations with high brittleness the influence of temperature and strain rate on deformation is small compared to that of pressure (Rybacki et al., 2015; Herrmann et al., 2018). Shales with high brittleness index are preferred reservoir rocks since they are believed to be easily stimulated and to contain abundant natural fractures, whereas those with low brittleness show fast fracture healing and proppant embedment. In that respect, the investigated Alum Shale Formation is expected to be an unconventional reservoir rock of medium quality.

\section{Conclusions and outlook}

The Alum Shale Formation is a unique early Phanerozoic sedimentary unit with geochemical features due to the coupled occurrences of high TOC content, an abnormally high uranium content up to several hundreds of ppm (carbonaceous Kolm lenses with up to $8,000 \mathrm{ppm} \mathrm{U}$ ) and a relatively uniform mineralogical and organic matter composition. Especially the high uranium content allowed for a variety of processes leading to unusual properties considering its role as a source rock in a conventional sense and as an unconventional shale play.

The rocks of the Alum Shale Formation are the source for conventional oil, and reservoirs for unconventional oil and gas. They are considered the main source rocks for oil accumulations in Lower Palaeozoic reservoirs of the Baltic Basin, but the potential for conventional oil decreased 
due to the long lasting irradiation by $\alpha$-particles from the decay of the high content in ${ }^{238} \mathrm{U}$. Today, even immature rocks of the Alum Shale Formation have a gas potential due to a complex chain of alteration processes affecting the organic matter (e.g., cross-linking, demethylation, aromatization, etc.). In overmature samples the high residual TOC content is caused by low expulsion efficiencies and an increase of inert carbon in kerogen with increasing maturity.

Biogenic methane is also a resource in the rocks of the Alum Shale Formation in southern Sweden, and is due to oil alteration. Oil was generated by local magmatic intrusions during the Carboniferous and Permian, impregnated basal portions of the strata in southern Sweden, and was later degraded due to glacial meltwater from the Pleistocene ice cover leading to biogenic methane formation.

The rocks of the Alum Shale Formation have a relatively low organic microporosity at high thermal maturity. Despite their age of nearly half a billion years and the high uranium content, there is the still existing reactivity in terms of microbial gas production. Such processes may have consequences for localized deep biospheres and need further investigations.

To verify the hypothesis that a high uranium content may lead to atypical organic geochemical characteristics needs further investigations, especially of the basinal facies of the Alum Shale Formation. Here, lower uranium content prevails and another factor has to be taken into account, e.g., yet unknown biopolymeric or carotenoid-derived precursors from algae and bacteria.

Many further questions about the Alum Shale Formation still remain unanswered. It is yet unclear how the organic matter was preserved during the deposition, and which role organo-mineral nanocomposites may have played. Another issue relates to the distribution and phase behaviour of uranium in the sediments. In marginal depositional settings (such as the Koporie Formation) significant sources were detrital U-bearing mineral phases such as zircon, apatite, etc. which were eroded from the surrounding and exposed Precambrian basement in the East. However, organicinorganic interactions at interfaces during deposition of the Alum Shale Formation have probably enabled adsorption of a significant portion of the uranium, which is difficult to detect and to specify in the rock yet. Probably, the uranium is mainly bound to the mineral matrix, and not to the organic matter (Yang et al., 2019). Still, this portion is an important factor for petroleum alteration over a half a billion years lasting period which led to a gas potential even in the immature part of the Alum Shale Formation.

The Pleistocene glaciation and the following melting of glaciers had a further influence on the Alum Shale Formation in terms of petroleum potential, either destructive or enhancing. Meltwater from Pleistocene glaciers at the eastern basin margin led to the oxic mobilization of previously insoluble U(IV) by leaching coarser-grained intervals. Today these leached intervals mimic a higher alteration and a gas potential rather than an oil potential. On the other hand, meltwater diluted saline brines and thus enabled microbial methane gas formation by oil alteration in southern Sweden. 
The petrophysical properties of the Alum Shale Formation are important factors for the evaluation as an unconventional play. The mechanical nature of the nearly carbonate-free Alum Shale Formation seemingly resembles the Jurassic Haynesville Shale from Texas with its characteristic interparticle porosity in a carbonate matrix, but which obviously differs from the mineralogically similar Marcellus Shale. The brittleness characteristics classify the rocks of the Alum Shale Formation as an unconventional resource of medium quality. Furthermore, experiments in the laboratory showed that the fluid transport properties of the Alum Shale Formation are highly dependent on a variety of factors. The permeability covers a broad range from sub-nanodarcy to microdarcy $\left(6 \cdot 10^{-22}-8 \cdot 10^{-18} \mathrm{~m}^{2}\right)$, depending on fluid type $\left(\mathrm{He}, \mathrm{Ar}, \mathrm{CH}_{4}, \mathrm{H}_{2} \mathrm{O}\right)$, moisture content, anisotropy (i.e. parallel vs. perpendicular to the bedding), pore pressure $(0.4-3.2 \mathrm{MPa})$ and effective stress $(5-30 \mathrm{MPa})$ conditions.

Research about the Alum Shale Formation also opens a window for understanding extraterrestrial phenomena. The alteration of macromolecular organic matter in the uranium-rich Alum Shale Formation in response to $\alpha$-particle irradiation was considered as a geological analogue on Earth of processes on the Martian surface. Yang et al. (2020) compared Martian surface samples and the Alum Shale (here especially the Kolm), and found similarities which indicate that similar irradiation dosages may have led to comparable organic geochemical characteristics.

\section{Acknowledgements}

The authors thank the funding consortium of GASH and Brian Horsfield for organizing this multiclient project, and Helmholtz Centre GFZ for the possibility to continue research on the Alum Shale Formation. Arne Thorshøj Nielsen, Kai Mangelsdorf and Jens Kallmeyer were essential for the success of the GASH drilling campaign on Bornholm in 2010, and our colleagues in the home institutions were of great help and assistance. Special thanks go to Anja Schreiber and Richard Wirth for their expert support on FIB and TEM at GFZ, and also to Jian Wang for his expert support on beamline 10ID-1 at the CLS, which is supported by the NSERC, the CIHR, the NRC and the University of Saskatchewan. We have to sincerely thank all of them, and especially the anonymous reviewer for his critical and constructive suggestions.

\section{References}

Abelson, P.H., 1963. Organic geochemistry and the formation of petroleum: 6th World Petroleum Congress.

Adeboye, O.O. and Bustin, R.M., 2013. Variation of gas flow properties in coal with probe gas, composition and fabric: examples from western Canadian sedimentary basin. International Journal of Coal Geology, 108, 47-52.

Amann-Hildenbrand, A., Ghanizadeh, A. and Krooss, B.M., 2012. Transport properties of unconventional gas systems. Marine and Petroleum Geology, 31, 90-99. 
Andersson, A., Dahlman, B., Gee, D.G. and Snäll, S., 1985. The Scandinavian Alum Shales. Sveriges Geologiska Undersökning Ca, 56, 1-50.

Armands, G., 1972. Geochemical studies of uranium, molybdenum and vanadium in a Swedish Alum Shale. Stockholm University. Contributions in Geology, 27, 1-148.

Arndt S., Brumsack H.-J. and Wirtz K., 2006. Cretaceous black shales as active bioreactors: a biogeochemical model for the deep biosphere encountered during ODP Leg 207 (Demerara Rise). Geochim. Cosmochim. Acta, 70, 408-425.

Arning, E. T., Gaucher, E. C., van Berk, W. and Schulz, H.-M., 2015. Hydrogeochemical models locating sulfate-methane transition zone in marine sediments overlying black shales: A new tool to locate biogenic methane?. Marine and Petroleum Geology, 59, 563-574.

Baumann-Wilke, M., Bauer, K., Schovsbo, N. H. Stiller, M., 2012. P-wave traveltime tomography for a seismic characterization of black shales at shallow depth on Bornholm, Denmark. Geophysics, 77, 53-60.

Bernard, S., Benzerara, K., Beyssac, O., Brown, G.E, Grauvogel-Stamm, L. and Duringer, P., 2009. Ultrastructural and chemical study of modern and fossil sporoderms by Scanning Transmission X-ray Microscopy (STXM). Review of Palaeobotany and Palynology, 156, 248-261.

Bernard, S., Beyssac, O., Benzerara, K., Findling, N. and Brown Jr., G.E., 2010a. XANES, Raman and XRD signatures of anthracene-based cokes and saccharose-based chars submitted to high temperature pyrolysis. Carbon, 48, 2506-2516.

Bernard, S., Horsfield, B., Schulz, H.-M. and Fuentes, D., 2010b. Multi-scale detection of organic and inorganic signatures provides insights into gas shale properties and evolution. Chemie der Erde - Geochemistry, 70, 119-133.

Bernard, S., Horsfield, B., Schulz, H.-M., Wirth, R., Schreiber, A. and Sherwood, N., 2012a. Geochemical evolution of organic-rich shales with increasing maturity: a STXM and TEM study of the Posidonia Shale (Lower Toarcian, northern Germany). Marine and Petroleum Geology, 31,70-89.

Bernard, S., Wirth, R., Schreiber, A., Schulz, H.-M., and Horsfield, B., 2012b. Formation of nanoporous pyrobitumen residues during maturation of the Barnett Shale (Fort Worth Basin). International Journal of Coal Geology, 103, 3-11.

Bernard, S. and Horsfield, B., 2014. Thermal Maturation of Gas Shale Systems. Annual Review of Earth and Planetary Sciences, 42(1), 635-51.

Berry, W.B., Wilde, P., Quinby-Hunt, M.S, and Orth, C.J., 1986. Trace element signatures in Dictyonema Shales and their geochemical and stratigraphic significance. Norsk Geol. Tidsskr,, 66, 45-51.

Bharati, S., Larter, S.R., and Horsfield, B., 1992. The unusual source potential of the Cambrian Alum Shale in Scandinavia as determined by quantitative pyrolysis methods. In: 
SPENCER, A.M. (Ed.): Generation, Accumulation and Production of Europe's Hydrocarbons, II, Springer, Heidelberg, 103-110.

Bieniawski, Z.T. and Hawkes, I., 1978. Suggested methods for determing tensile strength of rock materials. Int. J. Rock Mech. Min. Sci. Geomech. Abstr., 15, 99-103.

Bishop, J.K.B., 1988. The Barite-Opal-Organic Carbon Association in Oceanic Particulate Matter. Nature, 332, 341-343.

Bojesen-Koefoed, J.A., Weiss, H., Kanev, K., Zdanavičiūtè, O. Khubldikov, A. and Pokorski, J., 2001. Petroleum in the Baltic syneclise and the peribaltic region composition and variability: 20th International Meeting on Organic Geochemistry, 1,419-420.

Braun, R.L. and Burnham, A.K., 1992. PMOD: a flexible model of oil and gas generation, cracking, and expulsion. Organic Geochemistry, 19, 161-172.

Breger, I.A. and Brown, A., 1962. Kerogen in the Chattanooga Shale: Study of its origin and composition suggests why these shales are not source beds for petroleum. Science, 137, 221-224.

Brownfield, M.E., Schenk, C.J., Charpentier, R.R., Klett, T.R., Pitman, J.K., Tennyson, M.E., Gaswirth, S.B., Mercier, T.J., Le, P.A. and Leathers, H.M., 2015. Assessment of undiscovered conventional and continuous oil and gas resources of the Baltic Depression Province, 2014, US Geological Survey.

Buchardt, B. and Lewan, M.D. 1990. Reflectance of vitrinite-like macerals as a thermal maturity index for Cambrian-Ordovician Alum Shale, southern Scandinavia. AAPG Bulletin, 74, 394-406.

Buchardt, B., Nielsen, A.T., and Schovsbo, N.H., 1997. Alun Skiferen i Skandinavien. Geologisk Tidsskrift, 3, 1-30.

Chang, C., Zoback, M.D. and Khaksar, A., 2006., Empirical relations between rock strength and physical properties in sedimentary rocks. Journal of Petroleum Science and Engineering, $51,223-237$.

Charlesby, A., 1954. The cross-linking and degradation of paraffin chains by high-energy radiation. Proceedings of the Royal Society of London A: Mathematical, Physical and Engineering Sciences, 60-74.

Colombo, U., Sironi, G. and Denti, E., 1964. A geochemical investigation upon the effects of ionizing radiation on hydrocarbons. J. Inst. Petrol., 50, 228-237.

Cooles, G.P., Mackenzie, A.S. and Quigley, T.M., 1986. Calculation of petroleum masses generated and expelled from source rocks. Organic Geochemistry, 10, 235-245.

Court, R.W., Sephton, M.A., Parnell, J. and Gilmour, I., 2006. The alteration of organic matter in response to ionising irradiation: Chemical trends and implications for extraterrestrial sample analysis. Geochimica et Cosmochimica Acta, 70, 1020-1039.

Curtis, M.E., Ambrose, R.J., Sondergeld, C.H. and Rai, C.S., 2012a. Microstructural investigation 
of gas shales in two and three dimensions using nanometer-scale resolution imaging. AAPG Bull., 96, 665-77.

Curtis, M.E., Cardott, B.J., Sondergeld, C.H., and Rai, C.S., 2012b. Development of organic porosity in the Woodford Shale with increasing thermal maturity. International Journal of Coal Geology, 103, 26-31.

Dahl, J., Hallberg, R. and Kaplan, I., 1988a. The effects of radioactive decay of uranium on elemental and isotopic ratios of Alum Shale kerogen. Applied Geochemistry, 3, 583-589.

Dahl, J., Hallberg, R. and Kaplan, I., 1988b. Effects of irradiation from uranium decay on extractable organic matter in the Alum Shales of Sweden. Organic Geochemistry, 12, 559571 .

Dahl, J., Chen, R.T. and Kaplan, I.R., 1989. Alum Shale Bitumen Maturation and Migration: Implications for Gotland's Oil. Journal of Petroleum Geology, 12, 465-476.

Dehairs, F., Chesselet, R. and Jedwab, J., 1980. Discrete Suspended Particles of Barite and the Barium Cycle in the Open Ocean. Earth and Planetary Science Letters, 49, 528-550.

di Primio, R. and Horsfield, B., 2006. From petroleum-type organofacies to hydrocarbon phase prediction. AAPG Bulletin, 90, 1031-1058.

Dieckmann, V., Schenk, H.J., Horsfield, B. and Welte, D.H., 1998. Kinetics of petroleum generation and cracking by programmed-temperature closed-system pyrolysis of Toarcian Shales. Fuel, 77, 23-31.

Disnar, J.R., and Sureau, J.F., 1990. Organic-Matter in Ore Genesis - Progress and Perspectives: Organic Geochemistry, 16, 577-599.

Douglas, A., Sinninghe-Damsté, J.S., Fowler, M., Eglinton, T. and De Leeuw, J., 1991. Unique distributions of hydrocarbons and sulphur compounds released by flash pyrolysis from the fossilised alga Gloeocapsomorpha prisca, a major constituent in one of four Ordovician kerogens. Geochimica et Cosmochimica Acta, 55, 275-291.

Durand, B., 2003. A history of organic geochemistry. Oil \& Gas Science and Technology-Revue D Ifp Energies Nouvelles, 58, 203-231.

Dworatzek, M., 1987. Sedimentology and petrology of carbonate intercalations in the Upper Cambrian Olenid shale facies of southern Sweden. Sveriges Geologiska Undersökning serie C81, $73 \mathrm{p}$.

Dymond, J., Suess, E. and Lyle, M., 1992. Barium in deep-sea sediment: a geochemical proxy for paleoproductivity. Paleoceanography, 7, 163-181.

Dyni, J.R., 2006. Geology and resources of some world oil shale deposits. U.S. Geological Survey Scientific Investigations Report 2005-5294, 42 p.

Egenhoff, S.O., Fishman, N.S., Ahlberg, P., Maletz, J., Jackson, A., Kolte, K., Lowers, H., Mackie, J., Newby, W. and Petrowsky, M., 2015. Sedimentology of SPICE (Steptoean positive carbon isotope excursion): A high-resolution trace fossil and microfabric analysis 
of the middle to late Cambrian Alum Shale Formation, southern Sweden. The Geological Society of America Special Paper 515.

Eglinton, T.I., Sinninghe-Damsté, J.S., Kohnen M.E.L. and De Leeuw, J.W., 1990. Rapid estimation of the organic sulfur-content of kerogens, coals and asphaltenes by pyrolysisgas chromatography. Fuel, 69, 1394-1404.

Erlström, M., Thomas, S.A., Deeks, N. and Sivhed, U., 1997. Structure and tectonic evolution of the Tornquist Zone and adjacent sedimentary basins in Scania and the southern Baltic Sea area. Tectonophysics, 271(3-4), 191-215.

Eseme, E., Urai, J., Krooss, B. and Littke, R., 2007. Review of mechanical properties of oil shales: implications for exploitation and basin modelling. Oil Shale, 24(2), 159-175.

Feisthauer, S., Siegert, M., Seidel, M., Richnow, H.H., Zengler, K., Gründger, F., and Krüger, M., 2010. Isotopic fingerprinting of methane and $\mathrm{CO} 2$ formation from aliphatic and aromatic hydrocarbons. Organic Geochemistry, 41, 482-490.

Formolo, M.J., Petsch, S.T., Martini, A.M. and Nüsslein, K., 2008. A new model linking atmospheric methane sources to Pleistocene glaciation via methanogenesis in sedimentary basins. Geology, 36, 139-142.

Fowler, M.G., 1992. The Influence of Gloeocapsomorpha prisca on the Organic Geochemistry of Oils and Organic-Rich Rocks of Late Ordovician Age from Canada. In: Schidlowski, M., Golubic, S., Kimberley, M.M., McKirdy, D.M. and Trudinger P.A. (Eds.): Early Organic Evolution, 336-356.

Francois, R., Honjo, S., Manganini, S.J. and Ravizza, G.E., 1995. Biogenic barium fluxes to the deep sea: Implications for paleoproductivity indicators. Global Biogeochemical Cycles, 9, 289-303.

Gasparik, M., Bertier, P., Gensterblum, Y., Ghanizadeh, A., Krooss, B. M. and Littke, R., 2014a. Geological controls on the methane storage capacity in organic-rich shales. International Journal of Coal Geology, 123, 34-51.

Gasparik, M., Rexer, T.F.T., Aplin, A.C., Billemont, P., De Weireld, G., Gensterblum, Y., Henry, M., Krooss, B.M, Liu, S., Ma, X., Sakurovs, R., Song, Z., Staib, G., Thomas, K. M., Wang, S., and Zhang, T., 2014b. First international inter-laboratory comparison of high-pressure $\mathrm{CH} 4, \mathrm{CO} 2$ and $\mathrm{C} 2 \mathrm{H} 6$ sorption isotherms on carbonaceous shales. International Journal of Coal Geology, 132, 131-146.

Gensterblum, Y., Ghanizadeh, A., Krooss, B.M., 2014. Gas permeability measurements on Australian subbituminous coals: fluid dynamic and poroelastic aspects. Journal of Natural Gas Science and Engineering, 19, 202-214.

Ghanizadeh, A., Gasparik, M., Amann-Hildenbrand, A., Gensterblum, Y. and Krooss, B.M., 2014. Experimental study of fluid transport processes in the matrix system of European organic-rich shales: I. Scandinavian Alum Shale. Marine and Petroleum Geology, 51, 79- 
99.

Goldschmidt, V.M., 1937. The principles of distribution of chemical elements in minerals and rocks. The seventh Hugo Müller Lecture, delivered before the Chemical Society on March 17th, 1937. Journal of the Chemical Society (Resumed), 655-673.

Han, F., Busch, A., Krooss, B.M., Liu, Z., van Wageningen, N. and Yang, J., 2010. Experimental study on fluid transport processes in the cleat and matrix systems of coal. Energy and Fuels, 24, 6653-6661.

Han, Y., Mahlstedt, N. and Horsfield, B., 2015. The Barnett Shale: Compositional fractionation associated with intraformational petroleum migration, retention and expulsion. AAPG Bulletin, 99, 2173-2202.

Han, Y., Horsfield, B., Wirth, R., Mahlstedt, N., Bernard, S., 2017. Oil retention and porosity evolution in organic-rich shales. AAPG Bulletin, 101, 807-827.

Heeremans, M., Faleide, J. I. and B. T. Larsen, 2004. Late Carboniferous-Permian of NW Europe: An introduction to a new regional map, in: Wilson, M., Neumann, E.-R., Davies, G. R., Timmerman, M. J., Heeremans, M. and Larsen, B. T. (Eds.), Permo-Carboniferous magmatism and rifting in Europe. Geological Society, London, Special Publications, v. 223 , p. $75-88$.

Henkel S., Mogollón, J.M., Nöthen, K., Franke, C., Bogus, K., Robin, E., Bahr, E., Blumenberg, M., Pape, T., Seifert, R., März, C., de Lange, G.J., and Kasten S., 2012. Diagenetic barium cycling in Black Sea sediments - A case study for anoxic marine sediments. Geochimica et Cosmochimica Acta, 88, 88-105.

Henningsen, L.M., Jensen, C.H., Schovsbo, N.H., Nielsen, A.T. and Pedersen, G.K., 2018. Shale fabric and organic nanoporosity in lower Palaeozoic shales, Bornholm, Denmark. Geological Survey of Denmark and Greenland Bulletin, 41, 17-20.

Herrmann, J., Rybacki, E. Sone, H. and Dresen, G., 2018. Deformation Experiments on Bowland and Posidonia Shale-Part I: Strength and Young's Modulus at Ambient and In Situ pc-T Conditions. Rock Mechanics and Rock Engineering, 51, 3645-3666.

Hildenbrand, A., Schlömer, S., Krooss, B.M, 2006. Gas breakthrough experiments on finegrained sedimentary rocks. Geofluids, 2, 3-23.

Hints, R., Hade, S., Soesoo, A. and Voolma, M., 2014. Depositional framework of the East Baltic Tremadocian black shale revisited. GFF, 136, 464-482.

Hoering, T. C. and Navale, V., 1987. A search for molecular fossils in the kerogen of Precambrian sedimentary rocks. Precambrian research, 34, 247-267.

Holba, A., Ellis, L., Dzou, I., Hallam, A., Masterson, W., Francu, J. and Fincannon, A., 2001. Extended tricyclic terpanes as age discriminators between Triassic, Early Jurassic and Middle-Late Jurassic oils. 20th International Meeting on Organic Geochemistry, Nancy, France, September 10-14, 2001, p. 464. 
Horsfield, B., 1989. Practical criteria for classifying kerogens: some observations from pyrolysisgas chromatography. Geochimica et Cosmochimica Acta, 53, 891-901.

Horsfield, B., Bharati, S., Larter, S.R., Leistner, F., Littke, R., Schenk, H.-J. and Dypvik, H., 1992. On the atypical petroleum-generating characteristics of alginite in the Cambrian Alum Shale. In: Schidlowski, M., Golubic, S., Kimberley, M.M., and Trudinger, P.A. (Eds.): Early Organic Evolution, 1, 257-266.

Horsfield, B., Disko, U. and Leistner, F., 1989. The micro-scale simulation of maturation: outline of a new technique and its potential applications. Geologische Rundschau, 78, 361-374.

Horsrud, P., 2001. Estimating Mechanical Properties of Shale From Empirical Correlations. SPE Drilling \& Completion, SPE 56017.

Jaraula, C.M.B., Schwark, L., Moreau, X., Pickel, W., Bagas, L and Grice, K., 2015. Radiolytic alteration of biopolymers in the Mulga Rock (Australia) uranium deposit. Applied Geochemistry, 52, 97-108.

Jarvie, D.M., Hill, R.J., Ruble, T.E. and Pollastro, R.M., 2007. Unconventional shale-gas systems: The Mississippian Barnett Shale of north-central Texas as one model for thermogenic shale-gas assessment. AAPG Bulletin, 91, 475-499.

Jensen, J.B. and Hamann, N.E., 1989. Geological mapping of Mesozoic deposits along the eastern margin of the Rønne Graben, offshore Bornholm, Denmark. Bulletin of the Geological Society of Denmark, 37, 237-260.

Kamali-Asl, A., Ghazanfari, E., Newell, P. and Stevens, M., 2018. Elastic, viscoelastic, and strength properties of Marcellus Shale specimens. Journal of Petroleum Science and Engineering, 171, 662-679.

Kanev, S., Margulis, L., Bojesen-Koefoed, J.A., Merta, W.A.W.H. and Zdanaviciute, O., 1994. Oils and Hydrocarbon Source Rocks of the Baltic Syneclise. Oil \& Gas Journal, 92, 69-73.

Kaznacheev, K. and Hegmann, T., 2007. Molecular ordering in a biaxial smectic-A phase studied by scanning transmission X-ray microscopy (STXM). Phys. Chem. Chem. Phys., 9, 17051712.

Kennedy, M.J., Löhr, S.C., Fraser, S.A. and Baruch, E.T., 2014. Direct evidence for organic carbon preservation as clay-organic nanocomposites in a Devonian black shale; from deposition to diagenesis. Earth and Planetary Science Letters, 388, 59-70.

Kosakowski, P., Wrobel, M. and Poprawa, P., 2010. Hydrocarbon generation and expulsion modelling of the lower Paleozoic source rocks in the Polish part of the Baltic region. Geological Quarterly, 54, 241-256.

Kotarba, M.J., 2010. Origin of hydrocarbon gases accumulated in the Middle Cambrian reservoirs of the Polish part of the Baltic region. Geological Quarterly, 54, 197-204.

Kotarba, M.J. and Lewan, M.D., 2013. Sources of natural gases in Middle Cambrian reservoirs in Polish and Lithuanian Baltic Basin as determined by stable isotopes and hydrous 
pyrolysis of Lower Palaeozoic source rocks. Chemical Geology, 345, 62-76.

Krüger, M., Beckmann, S., Engelen, B., Thielemann, T., Cramer, B., Schippers, A. and Cypionka, H., 2008. Microbial methane formation from hard coal and timber in an abandoned coal mine. Geomicrobiol J., 25, 315-321.

Krüger, M., van Berk, W., Arning, E.T., Jiménez, N., Schovsbo, N.H., Straaten, N., and Schulz, H.-M., 2014. The biogenic methane potential of European gas shale analogues: Results from incubation experiments and thermodynamic modelling. International Journal of Coal Geology, 136, 59-74.

Larter, S.R., Bowler, B.F.J., Li, M., Chen, M., Brincat, D., Bennett, B., Noke, K., Donohoe, P., Simmons, D., Kohnen, M., Allan, J., Telnaes, N. and Horstad, I., 1996. Molecular indicators of secondary oil migration distances. Nature, 383, 593-597.

Le Guillou, C., Bernard, S., De la Pena, F. and Le Brech, Y., 2018. XANES-Based Quantification of Carbon Functional Group Concentrations. Anal. Chem., 90, 8379-8386.

Leventhal, J., 1991. Comparison of organic geochemistry and metal enrichment in two black shales: Cambrian Alum Shale of Sweden and Devonian Chattanooga Shale of United States. Mineralium Deposita, 26, 104-112.

Leventhal, J. S., and C. N. Threlkeld, 1978. Carbon-13/carbon-12 isotope fractionation of organic matter associated with uranium ores induced by alpha irradiation. Science, 202, 430-432.

Lewan, M.D. and Buchardt, B., 1989. Irradiation of organic matter by uranium decay in the Alum Shale, Sweden. Geochimica et Cosmochimica Acta, 53, 1307-1322.

Lora, R.V., Ghazanfari, E., and Izquierdo, E.A., 2016. Geomechanical characterization of Marcellus shale. Rock Mechanics and Rock Engineering, 49, 3403-3424.

Lou, Q., Fariborz, G., Zhong, N., Wang, Y., Qiu, N., Skovsted, C.B., Suchý, V., Schovsbo, N.H., Morga, R., Xu, Y., Hao, J., Liu, A., Wu, J., Cao, W., Min, X., Wu, J., 2020. Graptolites as fossil geo-thermometers and source material of hydrocarbons: An overview of four decades of progress. Earth-Science Reviews, 200, 103000.

Loucks, R.G., Reed, R.M., Ruppel, S.C. and Jarvie, D.M., 2009. Morphology, genesis, and distribution of nanometer-scale pores in siliceous mudstones of the Mississippian Barnett Shale. J. Sediment. Res., 79, 848-61.

Loucks, R.G., Reed, R.M., Ruppel, S.C. and Hammes, U., 2012. Spectrum of pore types and networks in mudrocks and a descriptive classification for matrix-related mudrock pores. AAPG Bull., 96, 1071-98.

Lüning, S., Shahin, Y.M., Loydell, D., Al-Rabi, H.T., Masri, A., Tarawneh, B. and Kolonic, S., 2005. Anatomy of a world-class source rock: Distribution and depositional model of Silurian organic-rich shales in Jordan and implications for hydrocarbon potential. AAPG Bulletin, 89, 1397-1427.

Mahlstedt, N. and Horsfield, B., 2019. Thermovaporisation: a screening tool for the gas-sorptive 
properties of source rocks. Organic Geochemistry 131, 1-4.

Martini, A. M., Walter, L.M., Budai, J.M., Ku, T.C.W., Kaiser, C.J. and Schoell, M., 1998. Genetic and temporal relations between formation waters and biogenic methane: Upper Devonian Antrim Shale, Michigan Basin, USA. Geochimica et Cosmochimica Acta, 62, 1699-1720.

Martini, A. M., Walter, L.M., Ku, T.C.W., Budai, J.M., McIntosh, J.C. and Schoell, M., 2003. Microbial production and modification of gases in sedimentary basins: A geochemical case study from a Devonian shale gas play, Michigan basin. AAPG Bulletin, 87, 1355-1375.

Massarotto, P., 2002. 4-D Coal Permeability under True Triaxial Stress and Constant Volume Conditions. Thesis $(\mathrm{PhD})$. The University of Queensland, Brisbane, Australia.

McIntosh, J. C., Walter, L-M. and Martini, A.M., 2002. Pleistocene recharge to midcontinent basins: Effects on salinity structure and microbial gas generation. Geochimica et Cosmochimica Acta, 66, 1681-1700.

McIntosh, J. C., Walter, L-M. and Martini, A.M., 2004. Extensive microbial modification of formation water geochemistry: Case study from a Midcontinent sedimentary basin, United States. GSA Bulletin, 116, 743-759.

Meier, T., Rybacki, E., Reinicke, A. and Dresen, G., 2013. Influence of borehole diameter on the formation of borehole breakouts in black shale. International Journal of Rock Mechanics and Mining Sciences, 62, 74-85.

Meier, T., Rybacki, E., Backers, T. and Dresen, G., 2015. Influence of Bedding Angle on Borehole Stability: A Laboratory Investigation of Transverse Isotropic Oil Shale. Rock Mechanics and Rock Engineering, 48, 1535-1546.

Mens, K., Viira, V., Paalits, I., and Puura, I., 1993. Upper Cambrian biostratigraphy of Estonia. Proceedings of the Estonian Academy of Science: Geology, 42, 148-159.

Merkel, B. J., and Arab, A., 2015. Uranium - Past and Future Challenges. Cham, Springer International Publishing.

Møller. L. N. N. and Friis. H., 1999. Petrographic evidence for hydrocarbon migration in Lower Cambrian sandstones, Bornholm, Denmark. Bulletin of the Geological Society of Denmark, 45, 117-127.

Nielsen, A.T. and Schovsbo, N.H., 2006. Cambrian to basal Ordovician lithostratigraphy in southern Scandinavia. Bulletin of the Geological Society of Denmark, 53, 47-92.

Nielsen, A.T. and Schovsbo, N.H., 2011. The Lower Cambrian of Scandinavia: Depositional environment, sequence stratigraphy and palaeogeography. Earth Science Reviews, 107, 207-310.

Nielsen, A.T. and Schovsbo, N.H., 2015. The regressive Early - Mid Cambrian 'Hawke Bay Event' in Baltoscandia: Epeirogenic uplift in concert with eustasy. Earth Science Reviews, 151, $288-350$. 
Nielsen, A.T., Schovsbo, N.H., Klitten, K., Woollhead, D. and Rasmussen, C.M.Ø., 2018. Gamma-ray log correlation and stratigraphic architecture of the Cambro-Ordovician Alum Shale Formation on Bornholm, Denmark: Evidence for differential syndepositional isostasy. Bulletin of the Geological Society of Denmark, 66, 237-273.

Obst, K., 2000. Permo-Carboniferous dyke magmatism on the Danish island Bornholm. Neues Jahrbuch für Geologie und Paläontologie-Abhandlungen, 218, 243-266.

Otmas, A., Grigiriev, G., Zitner, Y. and Soloveva, Y., 2018. Resource Base of the Kaliningrad Region and the Prospects for Expansion. Geomodel 2018.

Paterson, M.S., 1970. A high-pressure, high temperature apparatus for deformation. Int. J. Rock Mech. Min. Sci., 7, 517-526.

Pedersen, J. H., Karlsen, D.A., Spjeldnaes, N., Backer-Owe, K., Lie, J.E. and Brunstad, H., 2007. Lower Paleozoic petroleum from southern Scandinavia: Implications to a Paleozoic petroleum system offshore southern Norway. AAPG Bulletin, 91, 1189-1212.

Pedersen, G. K., 1989. The sedimentology of Lower Palaeozoic black shales from the shallow wells Skelbro 1 and Billegrav 1, Bornholm, Denmark. Bulletin of the Geological Society of Denmark, 37, 151-173.

Petersen, H.I., Schovsbo, N.H. and Nielsen, A.T., 2013. Reflectance measurements of zooclasts and solid bitumen in Lower Palaeozoic shales, southern Scandinavia: correlation to vitrinite reflectance. International Journal of Coal Petrology, 114, 1-18.

Pierce, A. P., Mytton, J.W. and Barnett, P.R., 1958. Geochemistry of uranium in organic substances in petroliferous rocks: Second. United Nations International Conference on the Peaceful Uses of Atomic Energy, 192-198.

Piske, J., and Neumann, E., 1990. Zur Ausbildung der Ablagerungen des Altpaläozoikums im Gebiet der südwestlichen Ostsee. Zeitschrift für angewandte Geologie, 36, 342-346.

Pool, W., Geluk, M., Abels, J., Tiley, G.J., Idiz, E., and Leenaarts, E., 2012. Assessment of an unusual European Shale Gas play: the Cambro-Ordovician Alum Shale, southern Sweden. Society of Petroleum Engineers. SPE-152339-MS. 12 p.

Poprawa, P., Kosakowski, P. and Wróbel, M., 2010. Burial and thermal history of the Polish part of the Baltic region. Geological Quarterly, 54, 131-142.

Rybacki, E., Reinicke, A., Meier, T., Makasi, M. and Dresen, G., 2015. What controls the mechanical properties of shale rocks? - Part I: Strength and Young's modulus. Journal of Petroleum Science and Engineering, 135, 702-722.

Rybacki, E., Meier, T., and Dresen, G., 2016. What controls the mechanical properties of shale rocks? - Part II: Brittleness. Journal of Petroleum Science and Engineering, 144, 39-58.

Rybacki, E., Herrmann, J., Wirth, R., and Dresen, G., 2017. Creep of Posidonia Shale at Elevated Pressure and Temperature. Rock Mech. Rock Engineering, 50, 3121-3140.

Samuelsson, J. and Middleton, M.F., 1998. The Caledonian foreland basin in Scandinavia: 
constraints by the thermal maturation of the Alum Shale. Geologiska Föreningens i Stockholm Förhandlingar, 120, 307-314.

Sanei, H., Petersen, H.I., Schovsbo, N.H., Jiang, C. and Goodsite, M.E., 2014. Petrographic and geochemical composition of kerogen in the Furongian (U. Cambrian) Alum Shale, central Sweden: reflections on the petroleum generation potential. International Journal of Coal Geology, 132, 158-169.

Schleicher, M., Köster, J., Kulke, H. and Weil, W., 1998. Reservoir and source-rock characterisation of the early Palaeozoic interval in the peribaltic syneclise, northern Poland. Journal of Petroleum Geology, 21(1), 33-56.

Schovsbo, N. H., 2001. Why barren intervals? A taphonomic case study of the Scandinavian Alum Shale and its faunas. Lethaia, 34, 271-285.

Schovsbo, N. H., 2002. Uranium enrichment shorewards in black shales: A case study from the Scandinavian Alum Shale. Journal of the Geological Society of Sweden, 124, 107-115.

Schovsbo, N. H., 2003. The geochemistry of Lower Palaeozoic sediments deposited on the margins of Baltica. Journal of the Geological Society of Sweden, 50, 11-27.

Schovsbo, N.H. and Nielsen, A.T., 2017. Generation and origin of natural gas in Lower Palaeozoic shales from southern Sweden. Geological Survey of Denmark and Greenland Bulletin, 38, 37-40.

Schovsbo, N.H., Esbensen, K.H., Nielsen, A.T., Derbez, E., Gaucher, E.C., Poirier-Coutansais, X., Riou, A., Tallone, P., and Milton-Taylor, D., 2015. Rock types in the Scandinavian Alum Shale resource play: definitions and predictions. 77th EAGE Conference \& Exhibition, Madrid, 1-4 June, 2015. Abstract.

Schovsbo, N.H., Nielsen, A.T., Klitten, K., Mathiesen, A. and Rasmussen, P., 2011. Shale gas investigations in Denmark: Lower Palaeozoic shales on Bornholm. Geological Survey of Denmark and Greenland Bulletin, 23, 9-12.

Schovsbo, N.H., Nielsen, A.T. and Gautier, D.L., 2014. The Lower Palaeozoic shale gas play in Denmark. Geological Survey of Denmark and Greenland Bulletin, 31, 19-22.

Schovsbo, N.H., Nielsen, A.T. and Erlström, M., 2016. Middle-Upper Ordovician and Silurian stratigraphy and basin development in southernmost Scandinavia. Geological Survey of Denmark and Greenland Bulletin, 35, 39-42.

Schovsbo, N.H., Nielsen A.T., Harstad, A.O. and Bruton, D.L., 2018. Stratigraphy and geochemical composition of the Cambrian Alum Shale Formation in the Porsgrunn core, Skien-Langesund district, southern Norway. Bulletin of the Geological Society of Denmark, 66, 1-20.

Schulz, H.-M., Biermann, S., van Berk, W., Krüger, M., Straaten, N., Bechtel, A., Wirth, R., Lüders, V., Schovsbo, N. H., and Crabtree, S., 2015. From shale oil to biogenic shale gas: Retracing organic-inorganic interactions in the Alum Shale (Furongian-Lower 
Ordovician) in southern Sweden. AAPG Bulletin, 99, 927-956.

Schulz, H., Wirth, R. and Schreiber, A., 2016. Nano-crystal formation of $\mathrm{TiO}_{2}$ polymorphs brookite and anatase due to organic-inorganic rock-fluid interactions. Journal of Sedimentary Research, 86, 59-72.

Schulz, H.-M., Yang, S., Panova, E. and Bechtel, A., 2019. The role of Pleistocene meltwatercontrolled uranium leaching in assessing irradiation-induced alteration of organic matter and petroleum potential in the Tremadocian Koporie Formation (Western Russia). Geochimica et Cosmochimica Acta, 245, 133-153.

Schwarzer, K., Ricklefs, K., Bartholomä, A. and Zeiler, M., 2008. Geological development of the North Sea and the Baltic Sea. Die Küste, 74, 1-17.

Sheppard, C.W. and Burton, V.L., 1946. The Effects of Radioactivity on Fatty Acids. Journal of the American Chemical Society, 68, 1636-1639.

Sinha, S., Braun, E.M., Determan, M.D., Passey, Q.R., Leonardi, S.A., Boros, J.A., Wood, A.C., Zirkle, T. and Kudva, R.A., 2013. Steady-state permeability measurements on intact shale samples at reservoir conditions e effect of stress, temperature, pressure, and type of gas. In: Society of Petroleum Engineers (SPE), Middle East Oil and Gas Show and Exhibition, Manama, Bahrain, SPE 164263.

Sivhed, U., Erlstrom, M., Bojesen-Koefoed, J.A. and Lofgren, A., 2004. Upper Ordovician carbonate mounds on Gotland, central Baltic Sea: Distribution, composition and reservoir characteristics. Journal of Petroleum Geology, 27, 115-140.

Sone, H. and Zoback, M.D., 2013. Mechanical properties of shale-gas reservoir rocks - Part 1: Static and dynamic elastic properties and anisotropy. Geophysics, 78, D381-D392.

Swanson, V.E., 1961. Geology and geochemistry of uranium in marine black shales: a review. Washington, US., U.S. Atomic Energy Commission.

Tegelaar, E.W. and Noble, R.A., 1994. Kinetics of hydrocarbon generation as a function of the molecular structure of kerogen as revealed by pyrolysis-gas chromatography. Organic Geochemistry, 22, 543-574.

Thommes, M., Kaneko, K., Neimark, A.V., Olivier, J.P., Rodriguez-Reinoso, F., Rouquerol, J. and Sing, K.S.W., 2015. Physisorption of gases, with special reference to the evaluation of surface area and pore size distribution (IUPAC Technical Report). Pure and Applied Chemistry, 87, 1051-1069.

Tissot, B.P. and Welte, D.H., 1984. Petroleum formation and occurrence. Springer-Verlag, Berlin, Heidelberg, 702pp.

U.S. Geological Survey, 2013. Undiscovered Gas Resources in the Alum Shale, Denmark, 2013. Fact Sheet 2013-3103. http://pubs.usgs.gov/fs/2013/3103

Vejbæk, O.V., Stouge, S. and Poulsen, K.D., 1994. Palaeozoic tectonic and sedimentary evolution and hydrocarbon prospectively in the Bornholm area. Danmarks Geologiske Undersøgelser 


$$
\text { A, 34, 1-23. }
$$

Wang, G. and Carr, T.R., 2012. Marcellus shale lithofacies prediction by multiclass neural network classification in the Appalachian Basin. Math. Geosci., 44, 975-1004.

Wang, J., Morin, C., Li., L. and Doran, A., 2009. Radiation damage in soft X-ray microscopy. Journal of Electron Spectroscopy and Related Phenomena, 170, 25-36.

Więcław, D., Kotarba, M.J. and Kowalski, A., 2010. Origin of oils accumulated in the Middle Cambrian reservoirs of the Polish part of the Baltic region. Geological Quarterly, 54, 205216.

Wrobel, M., and Kosakowski, P., 2010. 2-D modelling of petroleum processes of the lower Paleozoic strata in the Polish part of the Baltic region. Geological Quarterly, 54, 257-266.

Yang, S., Schulz, H.-M., Schovsbo, N.H. and Bojesen-Koefoed, J.A., 2017. Oil-source-rock correlation of the Lower Paleozoic petroleum system in the Baltic Basin (northern Europe). AAPG Bulletin, 101, 1971-1993.

Yang, S., Schulz, H.-M., Horsfield, B., Schovsbo, N.H., Noah, M., Panova, E., Rothe, H. and Hahne, K., 2018. On the changing petroleum generation properties of Alum Shale over geological time caused by uranium irradiation. Geochimica et Cosmochimica Acta, 229, 20-35.

Yang, S., Schulz, H.-M., Schovsbo, N. H., Wirth, R. and Mayanna, S., 2019. The organic geochemistry of "Kolm", a unique analogue for the understanding of molecular changes after significant uranium irradiation. International Journal of Coal Geology, 209, 89-93.

Yang, S., Schulz, H.-M., Horsfield, B., Schovsbo, N. H., Grice, K. and Zhang, J., 2020. Geological alteration of organic macromolecules by irradiation:Implication for organic matter occurrence on Mars. Geology, 48, 713-717.

Zdanavičiūtè, O., 2004. Geochemistry of oil and source rocks and petroleum potential of the western part of the Baltic Syneclise. Presentation.

Zdanaviciute, O., and Bojesen-Koefoed, J.A., 1997. Geochemistry of Lithuanian Oils and Source Rocks: A Preliminary Assessment. Journal of Petroleum Geology, 20, 381-402.

Zdanaviciute, O. and Lazauskiene, J., 2004. Hydrocarbon migration and entrapment in the Baltic Syneclise. Organic Geochemistry, 35, 517-527.

Zdanaviciute, O., Lazauskiene, J., Khoubldikov, A.I., Dakhnova, M.V. and Zheglova, T.P., 2012. The Middle Cambrian Succession in the Central Baltic Basin: Geochemistry of Oils and Sandstone Reservoir Characteristics. Journal of Petroleum Geology, 35, 237-254.

Zhang, D., Ranjith, P.G. and PERERA, M.S.A., 2016. The brittleness indices used in rock mechanics and their application in shale hydraulic fracturing: A review. Journal of Petroleum Science and Engineering, 143, 158-170. 


\section{Figures}

Fig. 1: Approximate original distribution of the Alum Shale Formation Formation and present day occurrence of lower Palaeozoic strata in southern Scandinavia. (redrawn and modified after Schovsbo et al., 2018). Russia* stands for Kaliningrad Oblast, a Russian exclave on the Baltic Sea.

Fig. 2: The Alum Shale Formation in the Gislövshammar-2 well with profiles of uranium, molybdenum, vanadium, sulphur (all ppm) and TOC contents (wt.\%). The gamma ray log in units counts per second $(\mathrm{C} / \mathrm{S})$ obtained in the borehole is shown in same track as the uranium concentrations. Geochemical data are from Schovsbo (2001, 2002). For full stratigraphical breakdown see Nielsen et al. (2018). Abbreviations: G: Gislöv Formation; K: Komstad Limestone Formation. See Fig. 3 for location of the well.

Fig. 3: Location of investigated boreholes with data in this manuscript is indicated by drilling rigs and names of the wells together with symbols for outcrops from which samples were taken and analysed.

Fig. 4: Paleogeography during the Furongian (late Cambrian) and Early Ordovician (Tremadocian).Fig. 5: Lithology of the Alum Shale Formation. (A) $3.2 \mathrm{~m}$ thick claystone interval from $14.6 \mathrm{~m}$ to $17.8 \mathrm{~m}$ depth with barite nodules (see arrows) in well Skelbro-2. (B) Barite nodules in well Skelbro-2. (C) Carbonate layer in shallow Östergötland well in southern Sweden with obvious growth of calcite crystals. (D) Larger calcite crystals as in (C). (E) Complete Alum Shale Formation sequence in shallow Östergötland well in southern Sweden. Each core box is $1 \mathrm{~m}$ in length. Left is bottom (B) of borehole, right is top (T). Lower Cambrian sandstones underlie the Alum Shale Formation, and Upper Ordovician carbonate are above. Sandstone is indicated by arrows. (F) Oil staining in Alum Shale Formation in shallow borehole in Östergötland.

Fig. 6: Thickness and thermal maturity of the Alum Shale Formation. Redrawn and modified after Buchardt et al. (1990, 1997) and Petersen et al. (2013). The information about the areas influenced by volcanics is from Heeremans et al. (2004). The thermal maturity of the Alum Shale Formation ranging from immature to anchi-metamorphic relates to Ro (\%) data which are recalculated data from graptolite and vitrinite-like particles (Buchardt et al., 1997, 1998; Petersen et al., 2013).

Fig. 7: Microscopic features of immature Alum Shale Formation. (A) Fluorescing lamalginite in well Östergötland in southern Sweden (polished section, ultraviolet illumination). (B) Graptolite rhabdosomes in Tremadocian Alum Shale Formation in well StP-4 close to St. Petersburg (polished section; ultraviolet illumination on the left, white light illumination on the right). (C) Highly fluorescing organic matter in uranium-rich lower part of Tremadocian Alum Shale Formation in well StP-4 close to St. Petersburg (polished section; ultraviolet illumination on the left, white light illumination on the right). (D) K-feldspar dissolution and kaolinite precipitation (thin section, parallel nicols; well Östergötland in southern Sweden). (E) Calcite crystals grown into bitumen impregnation (thin section, parallel nicols; well Östergötland in southern Sweden). 
(F) Massive calcite precipitation in a matrix of bitumen impregnation (thin section, crossed nicols; well Östergötland in southern Sweden).

Fig. 8: Transmission electron microscopy analyses of focused ion beam foils. (A) Newly formed illite grown in organic material, or clay-organic nanocomposites of detrital origin (bright field). (B) Newly formed feldspar grown into organic matter (high-angle annular dark field, HAADF). (C) Porous organic material surrounded by illite (bright field). The pores in the organic matter contain carbon-bearing gas $\left(\mathrm{CO}_{2}\right.$ or $\left.\mathrm{CH}_{4}\right)$. (D) Newly formed idiomorphic quartz crystal in organic matter (bright field). Arrows indicate fissures which might have facilitated diffusion in aqueous phase to enable ion transport and precipitation.

Fig. 9: Source rocks and reservoirs of the Baltic Basin (modified after Zdanavičiūtè, 2004).

Fig. 10: Terpane biomarker crossplot used to differ Alum Shale Formation from Llandovery source rocks. The extended tricyclic terpane ratio (ETR; according Holba et al., 2001) is calculated from $(\mathrm{C} 28+\mathrm{C} 29) /(\mathrm{C} 28+\mathrm{C} 29+18$ atrisnorneohopane $)$ in mass-to-charge ratio 191. Dot sizes indicate thermal maturity of investigated samples in order to evaluate the maturity dependency of the biomarkers. $\mathrm{C}_{24} \mathrm{TeT}=\mathrm{C}_{24}$ tetracyclic terpane; $\mathrm{C}_{26} \mathrm{TT}=\mathrm{C}_{26}$ tricyclic terpane; M. = Middle; $\mathrm{St}=$ sterane; $\mathrm{U} .=$ Upper.

Fig. 11: Uranium and TOC content of the Alum Shale Formation (modified after Schovsbo, 2002).

Fig. 12: Open-system pyrolysis GC-FID typing of petroleum type organofacies (acc. Horsfield, 1989) and kerogen type (Eglinton et al., 1990). See Fig. 3 for sample locations.

Fig. 13: Correlations between uranium content with compositional information derived from open pyrolysis experiments (Yang et al., 2018). (a) Gas percentages. (b) ortho-xylene percentages in ternary plot by Eglinton et al. (1990).

Fig. 14: Compositional kinetic model for an immature Alum Shale Formation sample from well Hällekis-1 (see Fig. 3 for location).

Fig. 15: Back-calculation of potential generation products of the Alum Shale Formation due to uranium irradiation (Yang et al., 2018).

Fig. 16: Event chart of the Alum Shale Formation hydrocarbon system.

Fig. 17: Comparison of methane (a) and carbon dioxide (b) generation rates (nmol g-1 $\mathrm{TOC} \mathrm{d}^{-1}$ ) of Alum Shale Formation samples in incubation experiments. Data for the Lower Jurassic Posidonia Shale are given for comparison as well as methane production rates for different types of coal and petroleum.

Fig. 18: The Alum Shale Formation in the Skelbro-2 well with obtained wire-line logs acquired in the well (c.f. Baumann-Wilke et al. 2012). For full stratigraphical breakdown correlation of Skelbro-2 and correlation to Gislövshammar-2 see Nielsen et al. (2018). See Fig. 3 for location of the well. Abbreviations: R: Rispebjerg sandstone; Kom: Komstad Limestone Formation. Legend as in Fig. 2.

Fig. 19: Organic geochemical proxies in the Alum ShaleFormation in well Skelbro-2 (Bornholm; 
drilled within the scope of the GASH project) resulting from Rock Eval pyrolysis and open pyrolysis together with organic geochemical data. HI: hydrogen index. Porosity data are taken from Ghanizadeh et al. (2014). Arrows indicate where samples have been taken for the different analyses described in the text.

Fig. 20: STXM characterization of the FIB foils extracted from the Alum Shale Formation samples investigated. The red squares indicate the location of the STEM images and EDXS maps shown in Fig. 18. A. STXM images collected below the carbon absorption energy. Organic compounds appear bright. B. STXM maps showing the spatial distribution of organic compounds in yellow. C. XANES spectra of these organic compounds.

Fig. 21: STEM images and corresponding elemental maps of the areas of the FIB foils comprised within the red squares of Fig. 14. Note that in contrast to STXM images, organic compounds appear dark on STEM images.

Fig. 22: Physical properties of petroleum generated at specific transformation ratios (left) and phase envelopes (right) for an immature Alum Shale Formation sample well Hällekis-1 (see Fig. 3 for location).

Fig. 23: Plot of $S_{2}$ signal from Rock Eval analysis versus (A) $C_{1-5}$ (methane to pentane) concentrations from thermovaporization, and (B) versus $\mathrm{C}_{1-5}$ (methane to pentane) concentrations from thermovaporization normalized against $\mathrm{g}$ S2.

Fig. 24: Effect of moisture content on slip-corrected gas $\left(\mathrm{He}, \mathrm{CH}_{4}\right)$ permeability coefficients as function of stress measured on a core plug from the Scandinavian Alum Shale Formation (sample Alum-2 in Fig. 13).

Fig. 25: Effect of stress on slip-corrected gas $\left(\mathrm{CH}_{4}\right)$ permeability coefficients measured on selected core plugs from the Scandinavian Alum Shale Formation. Mineralogy and helium porosity values of the core plugs are reported in the diagram. Upper sample: Alum-8, lower sample: Alum-2; see Fig. 13 for sampling position in well Skelbro-2. Middle sample: Alum Shale Formation sample from the Djupvik quarry; see Fig. 3 for sampling location.

Fig. 26: Approximate composition of Alum and other European (Posidonia, Bowland) and NAmerican (Barnett, Haynesville, Marcellus) shales. Alum Shale Formation is rich in weak (CTMP) phases, contains a moderate amount of strong (QFP) minerals and is almost free of carbonates. QFP $=$ quartz + feldspar + pyrite $),$ CTMP $=$ clays + total organic matter + micas + porosity, $\mathrm{Cb}=$ carbonates. Note that all fractions are given in vol $\%$, which is more relevant for mechanical properties than wt\% (for conversion see Rybacki et al., 2015). The composition of shales is estimated from data provided by Wang and Carr (2012), Sone and Zoback (2013), Gasparik et al. (2014b), Rybacki et al. (2015), Lora et al. (2016), Herrmann et al. (2018), and Kamali-Asl et al. (2018).

Fig. 27: Stress strain curves of Alum Shale Formation measured under triaxial deformation conditions $\left(\mathrm{P}=50 \mathrm{MPa}, \mathrm{T}=100^{\circ} \mathrm{C}\right.$, strain rate $\left.=5 \times 10-4 \mathrm{~s}-1\right)$. The strength of Alum Shale 
Formation is comparable to that of Posidonia and Haynesville shales, whereas Bowland, Barnett and Marcellus is considerably stronger. For comparison, the uniaxial strength of Alum Shale Formation deformed under ambient conditions $\left(\mathrm{P}=0.1 \mathrm{MPa}, \mathrm{T}=25^{\circ} \mathrm{C}\right.$, strain rate $=7 \times 10-5 \mathrm{~s}-$ 1) is significantly lower than deformed under triaxial conditions. (n) denotes loading normal to bedding and (p) parallel to bedding. Data are compiled from Rybacki et al. (2015) and Herrmann et al. (2018). 


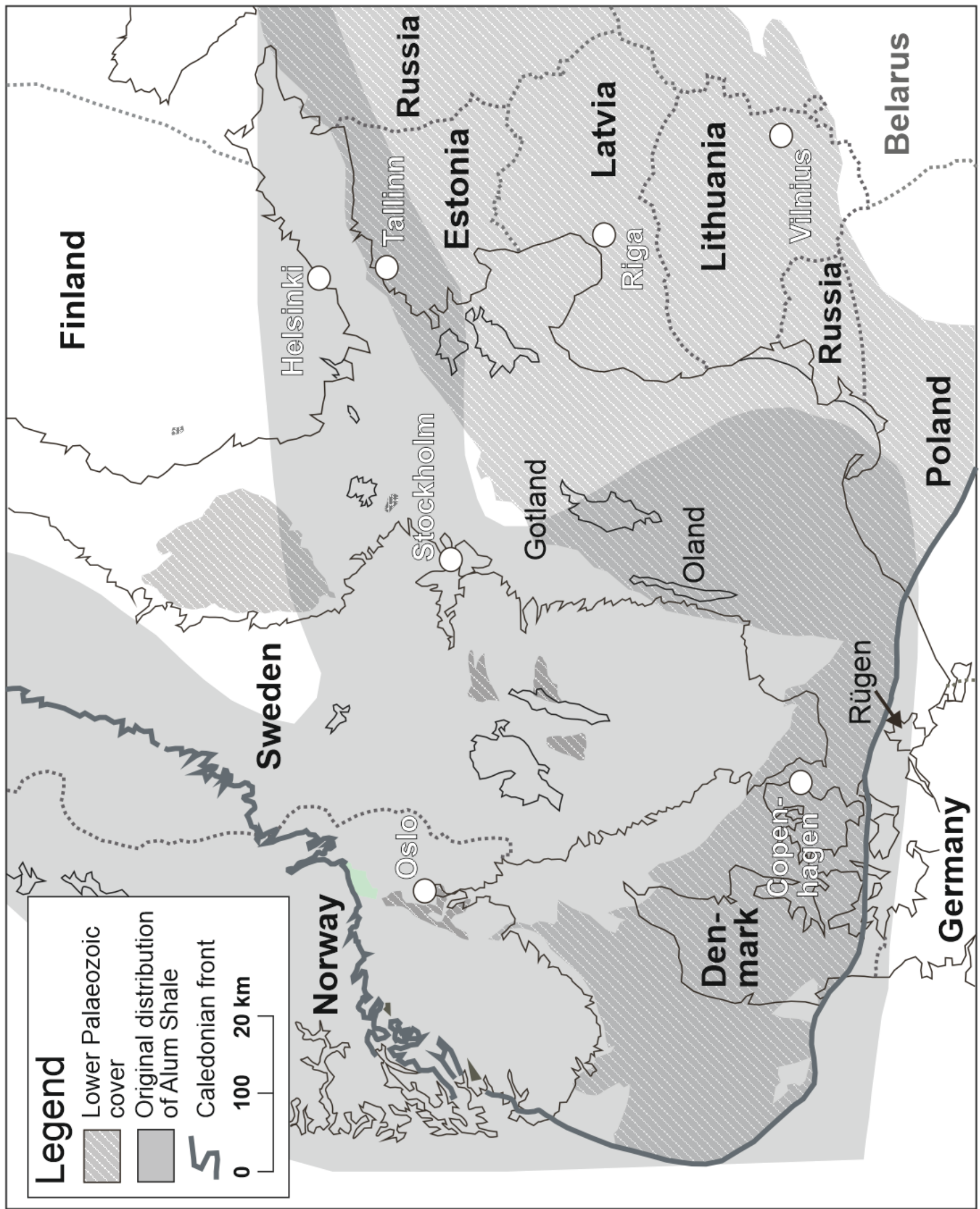


흠
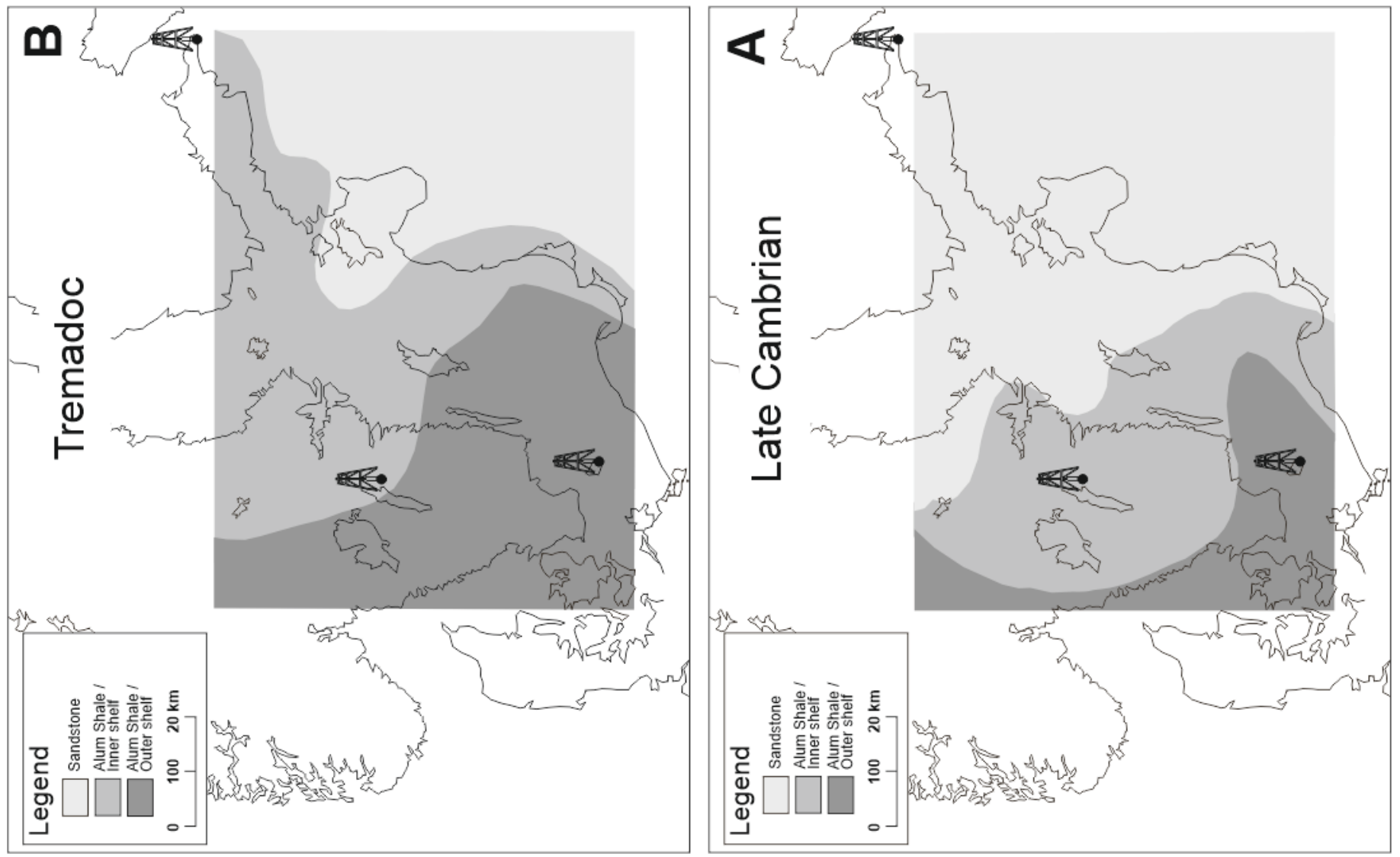


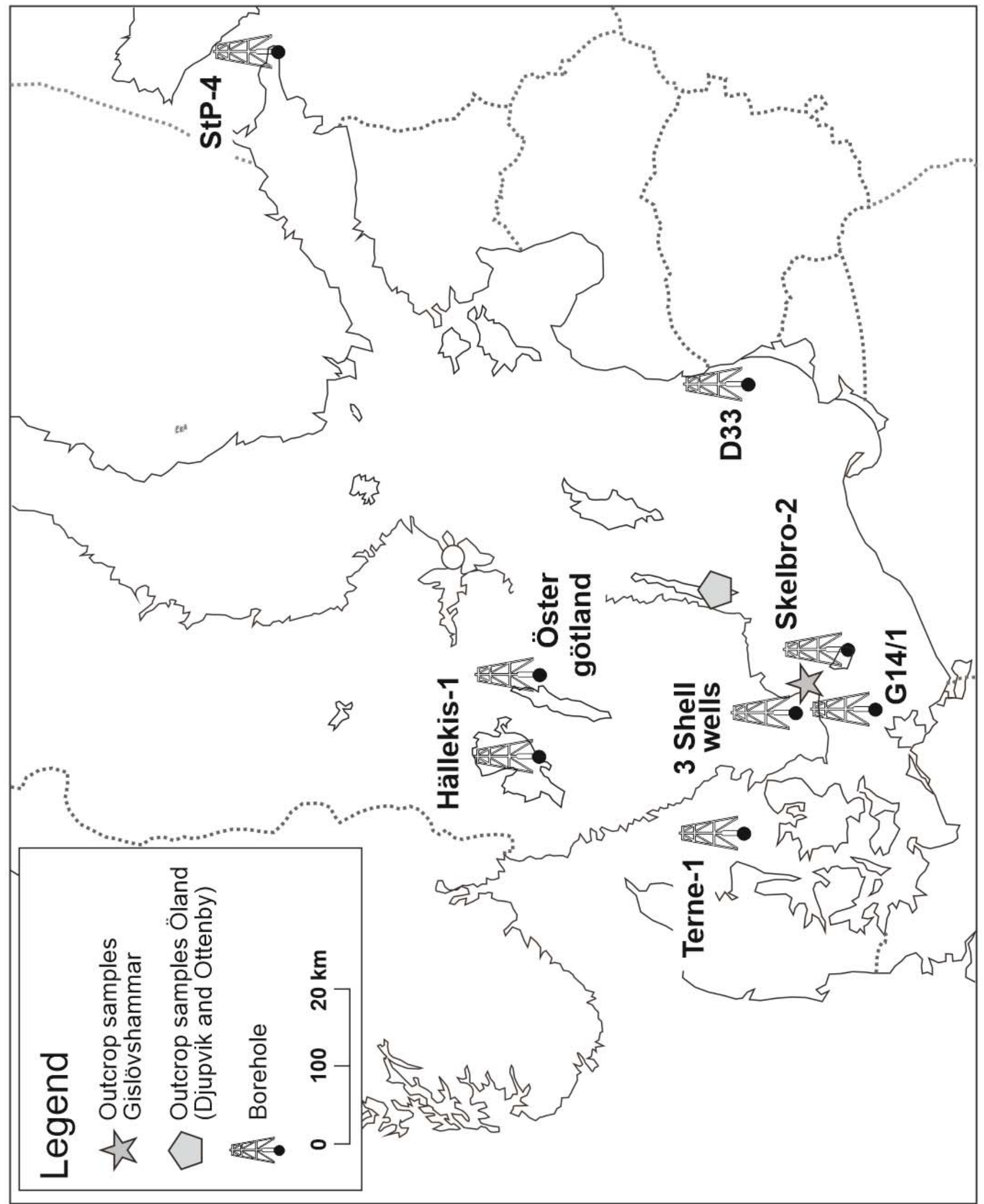



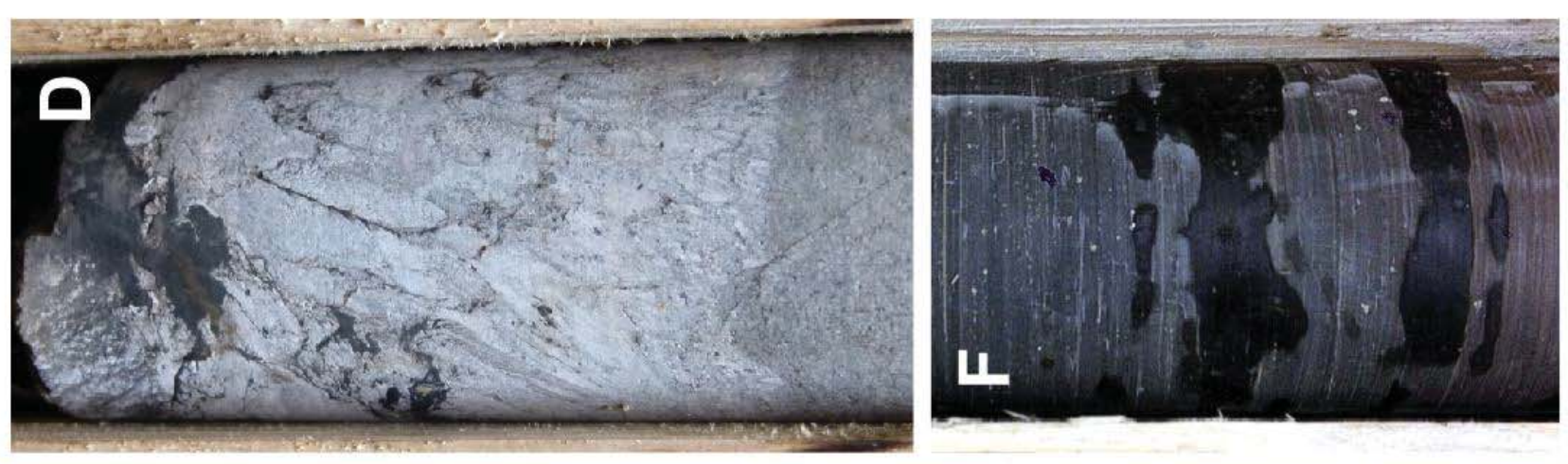

훈
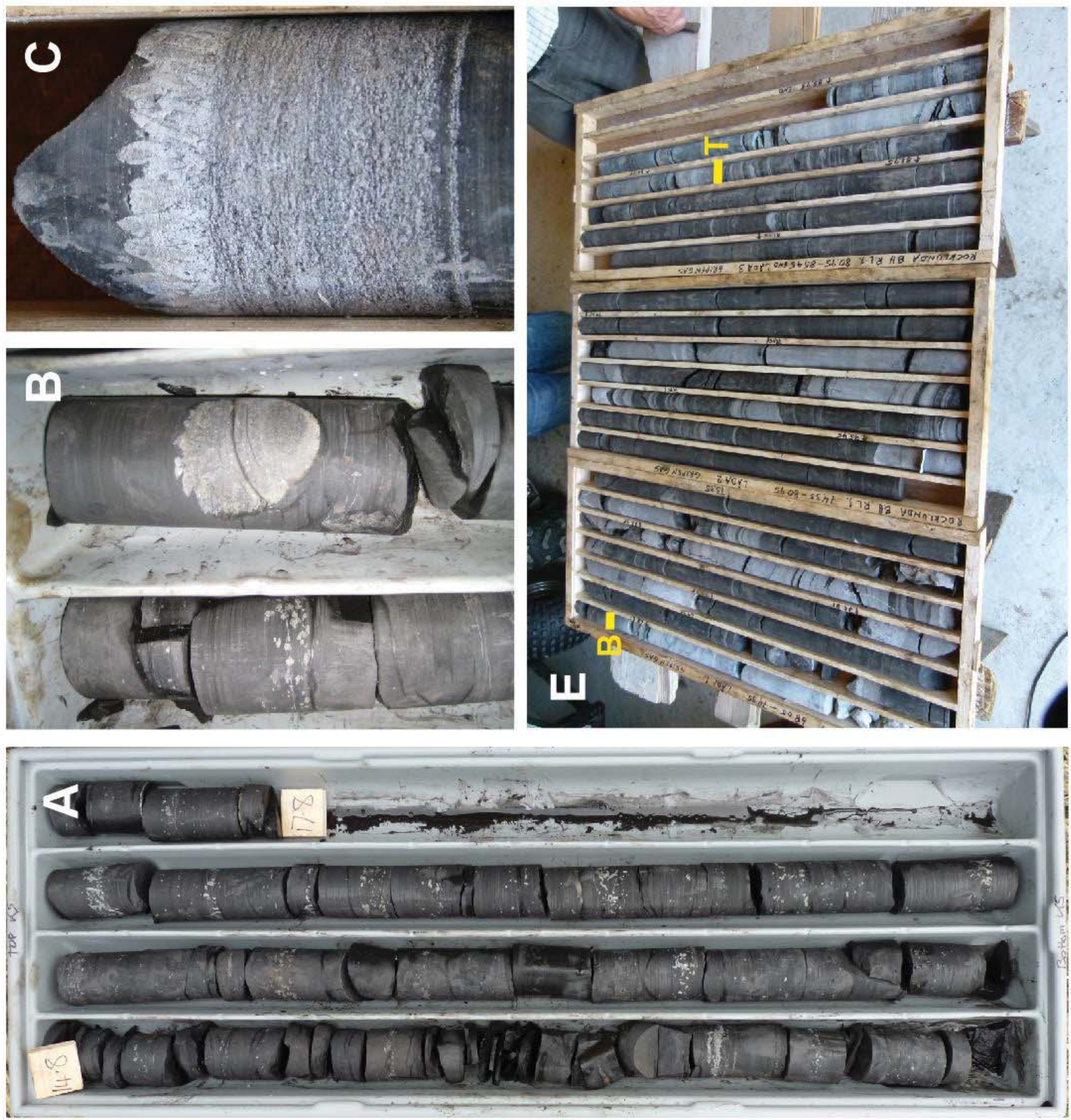
온

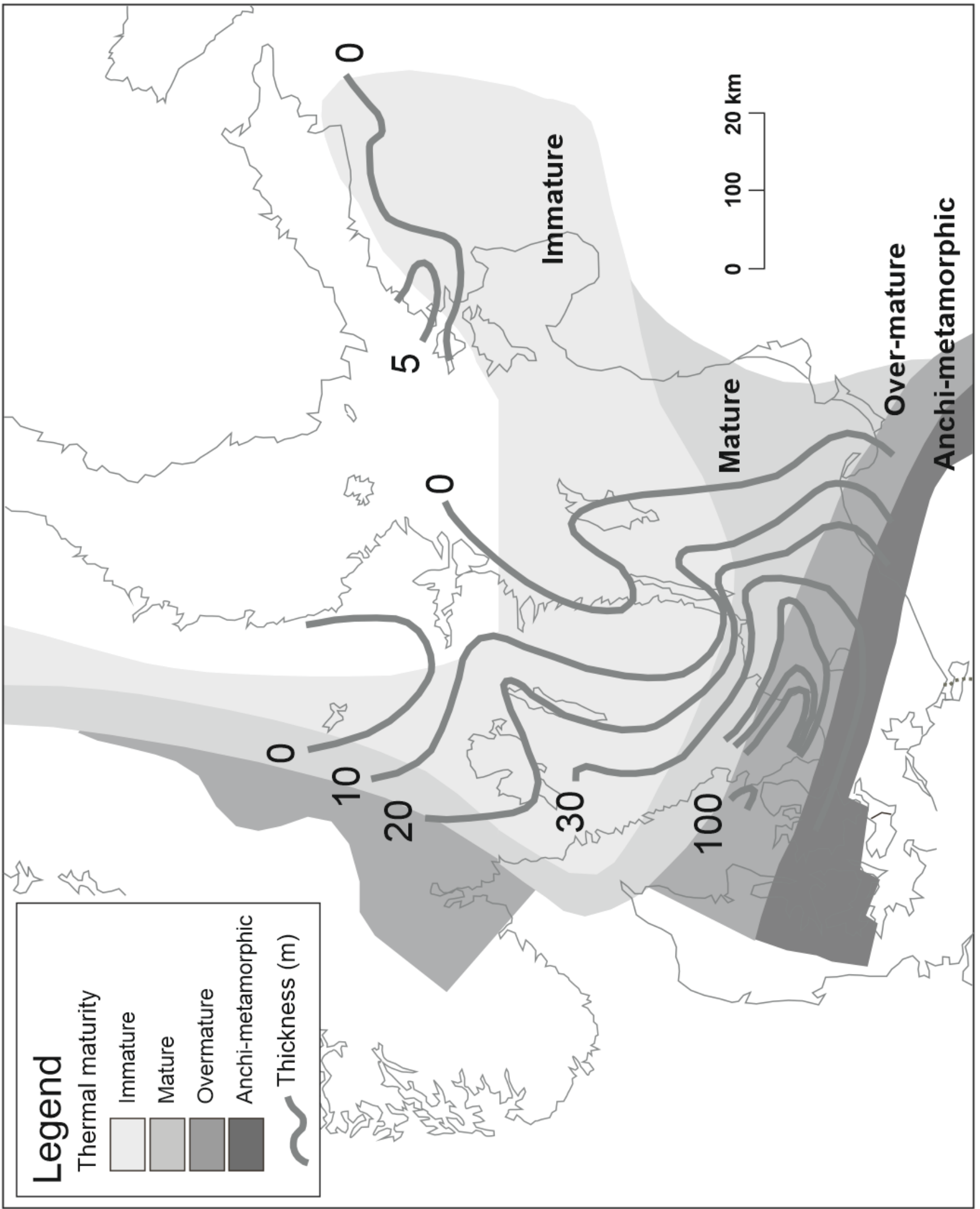


움
호
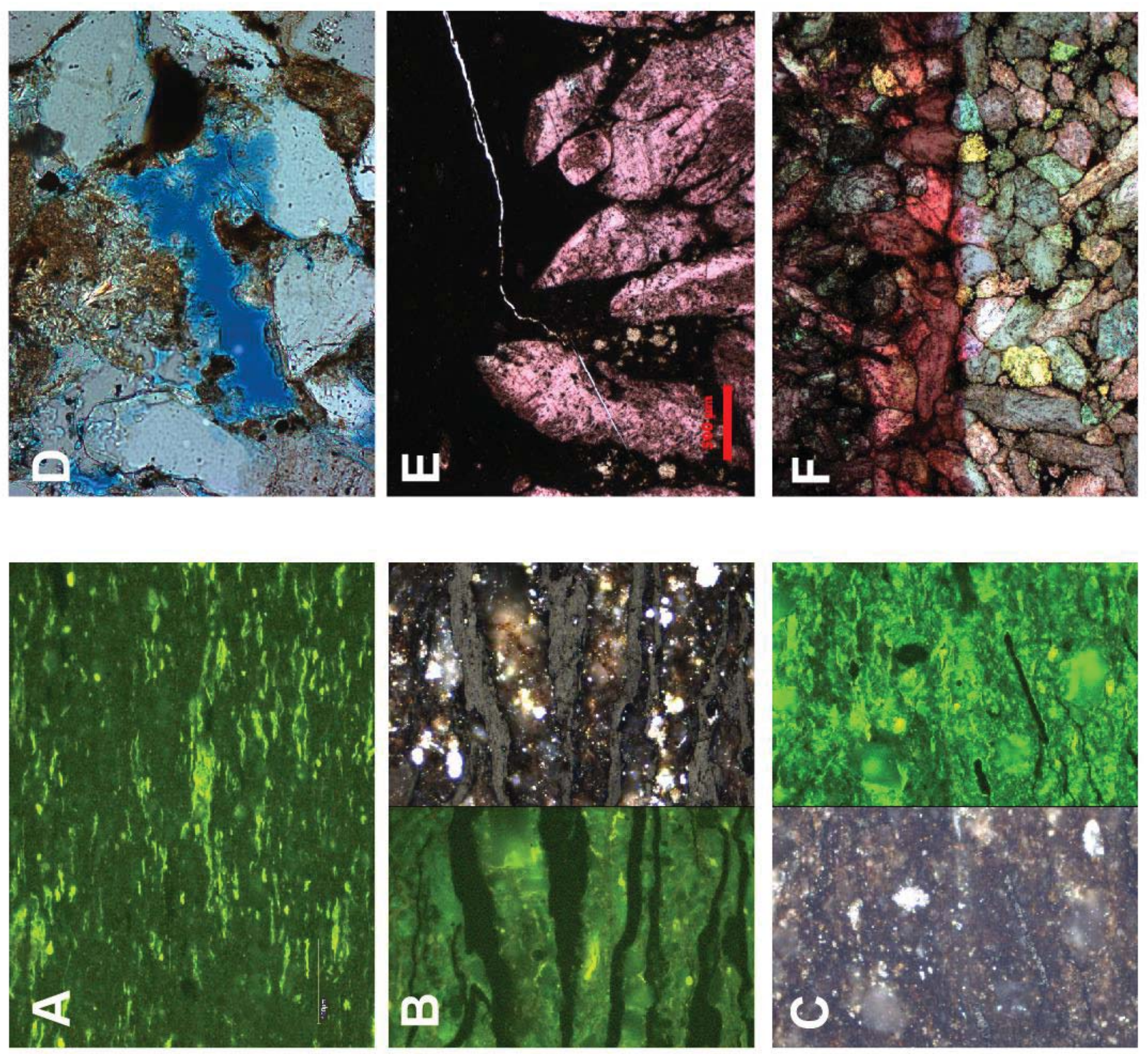
훔
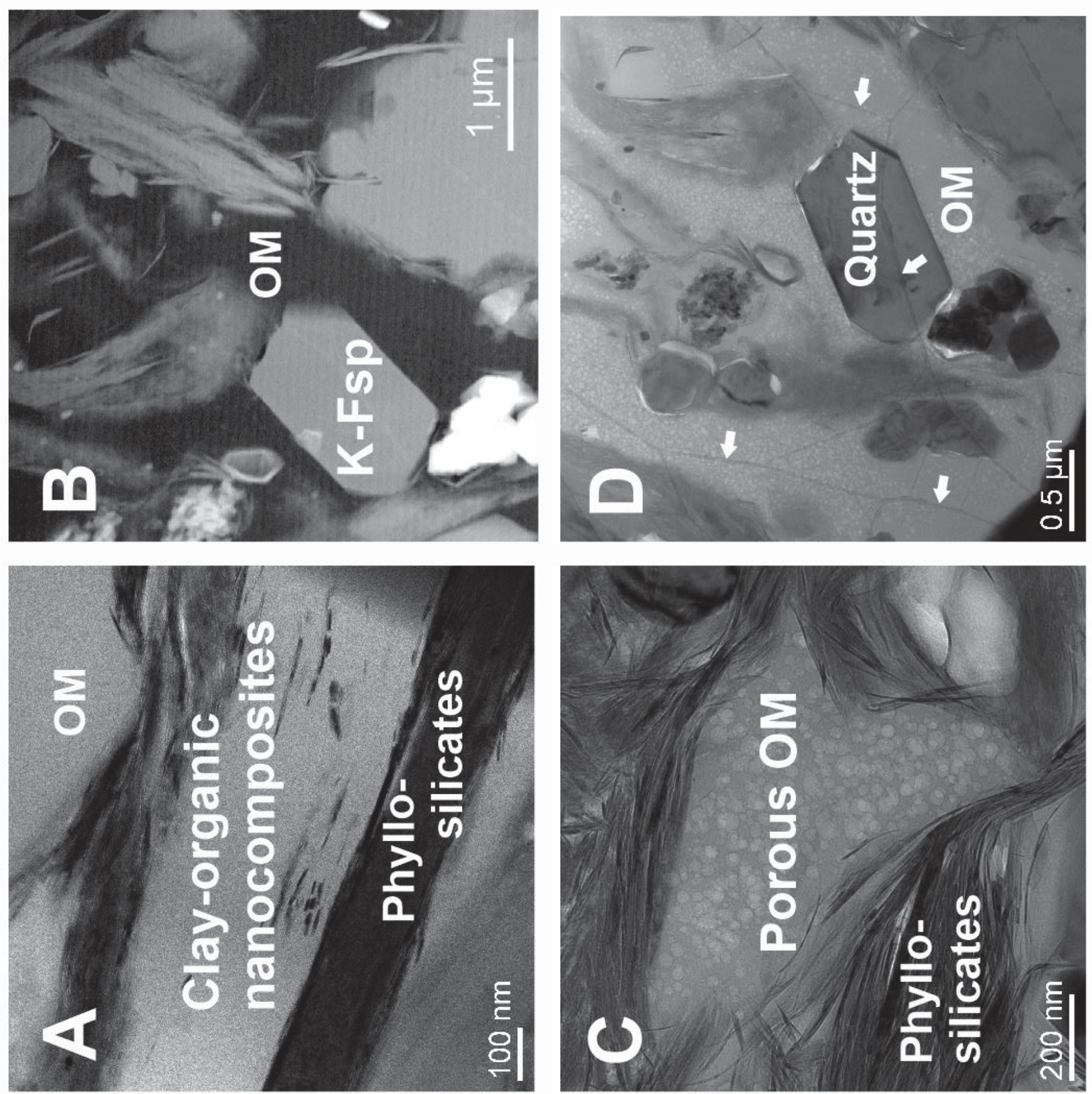
$\infty$
흠

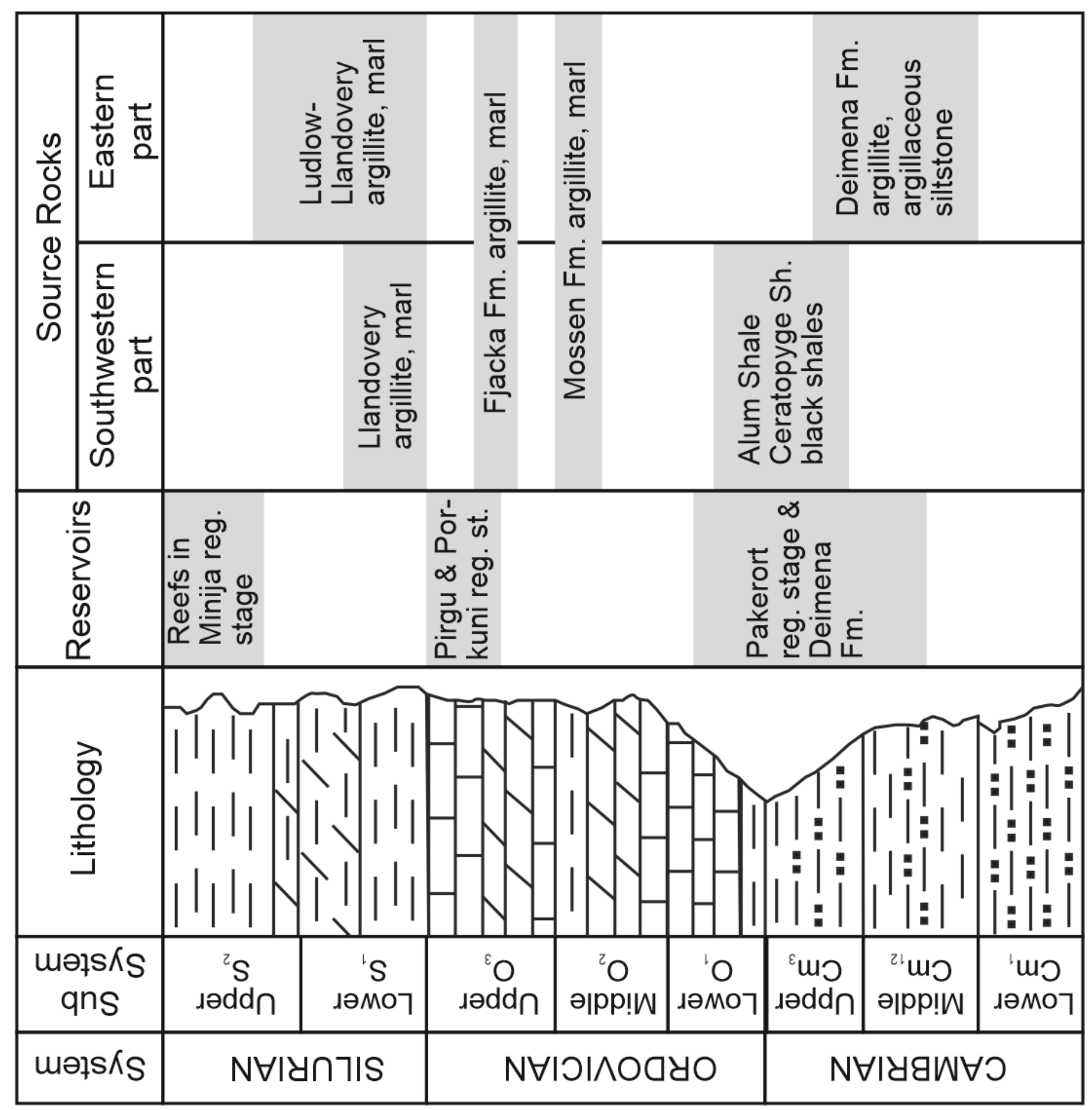


o
iㅁ

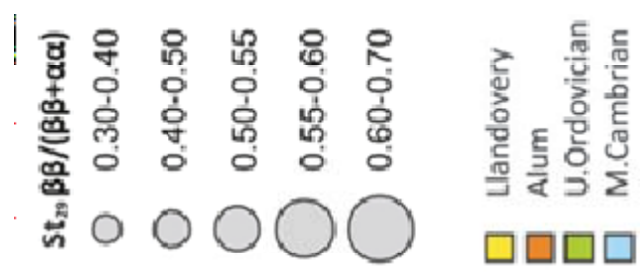

Оั๋

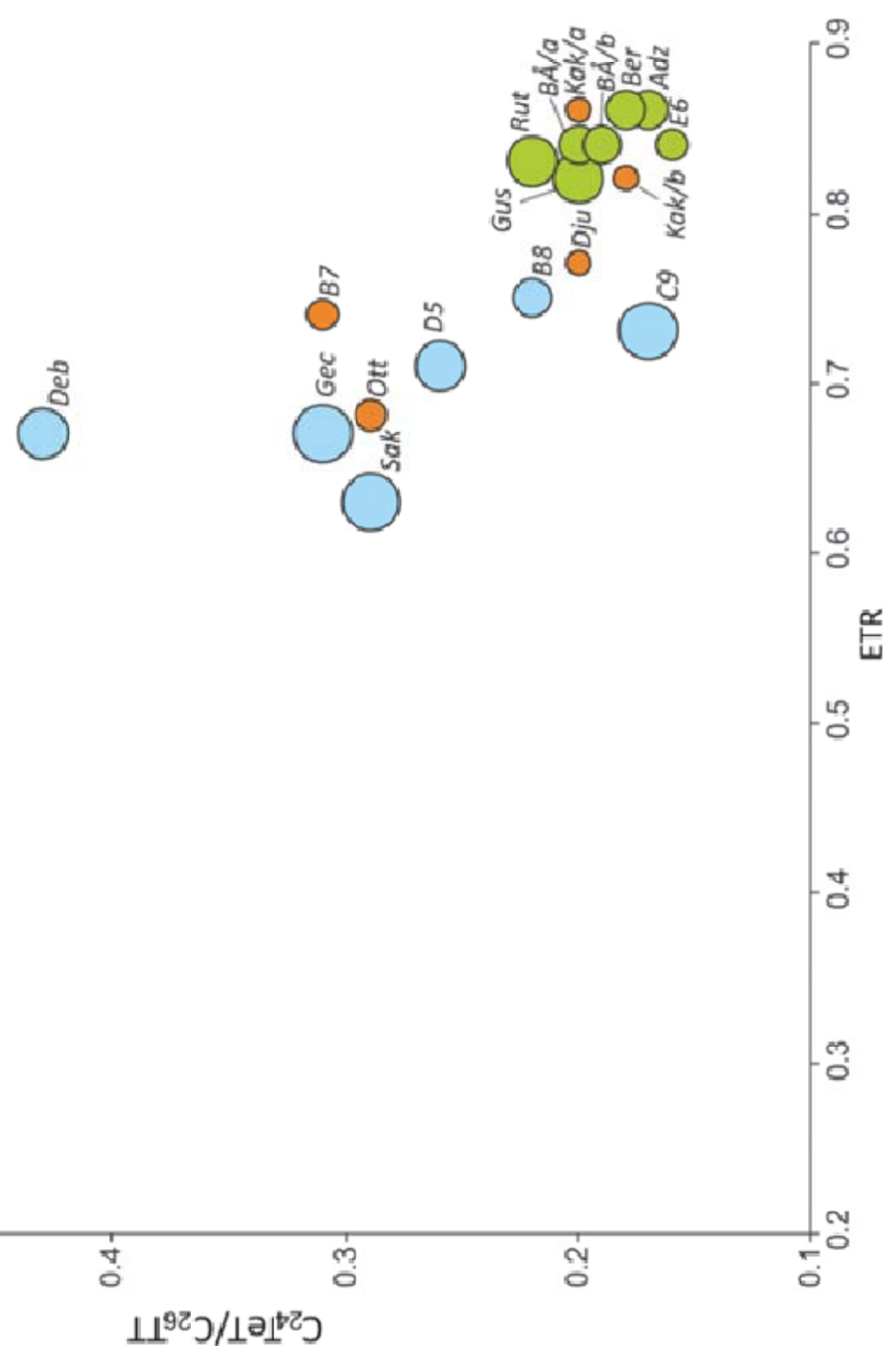




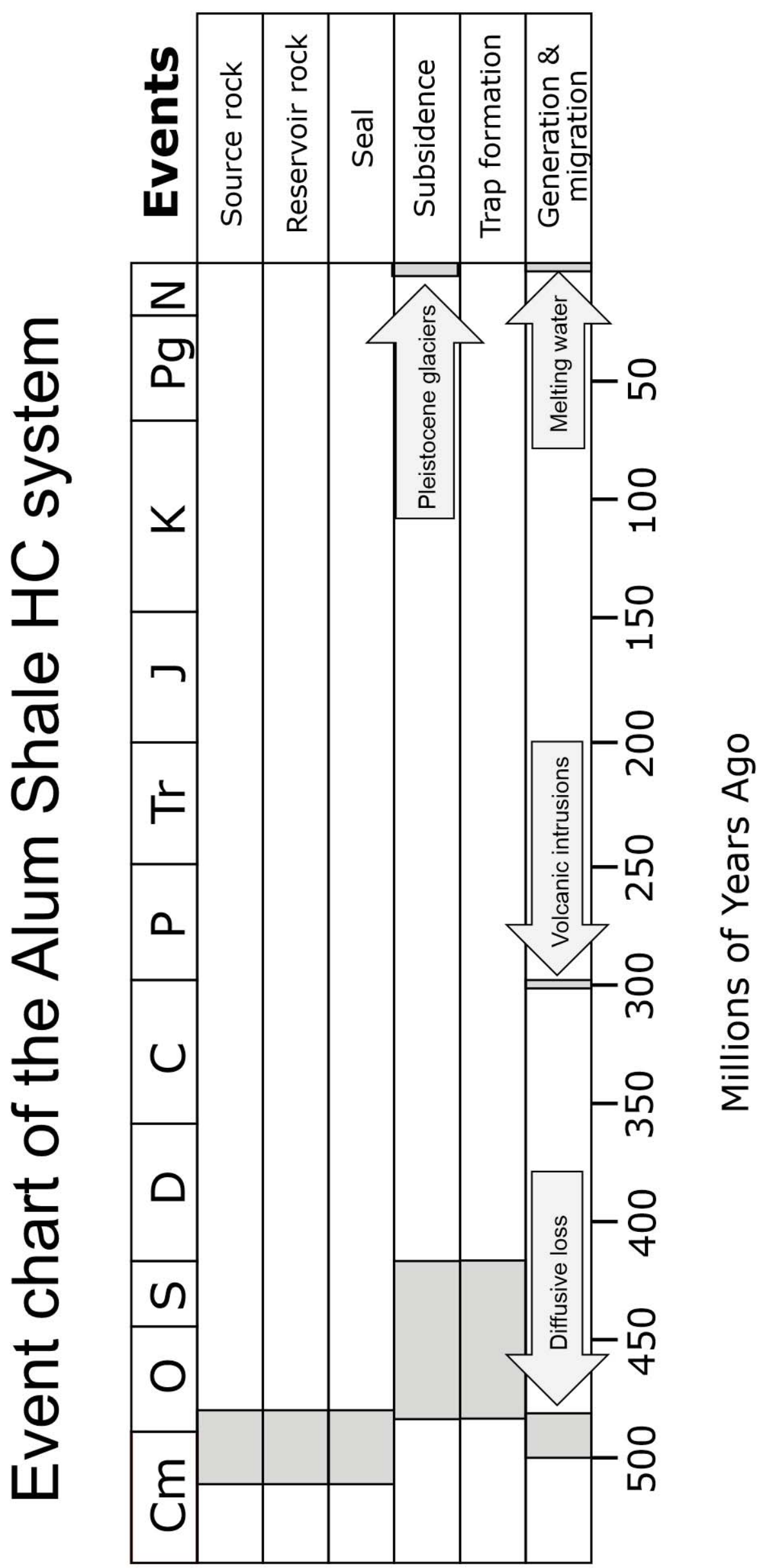




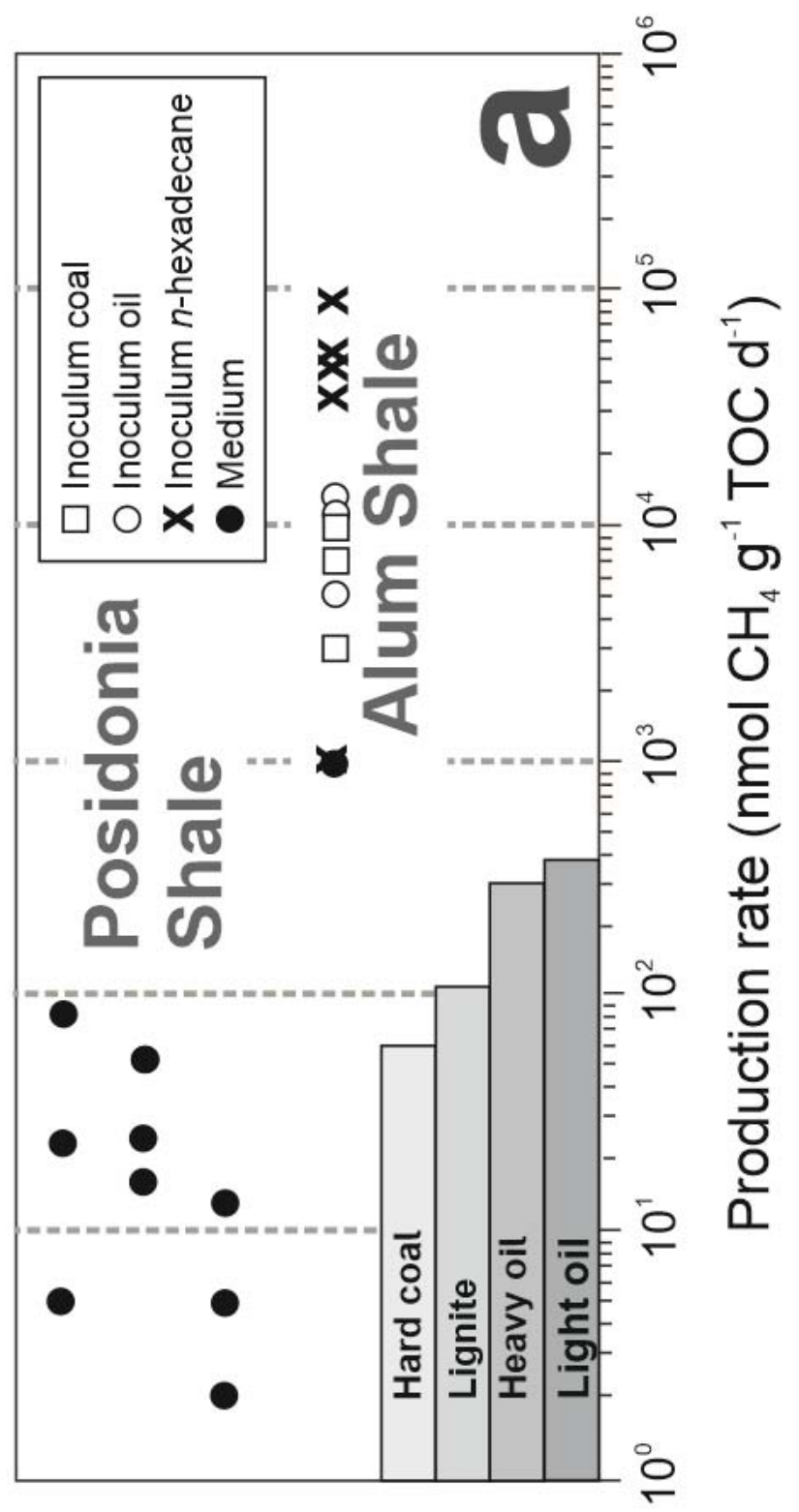

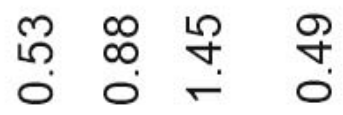

(

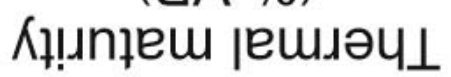

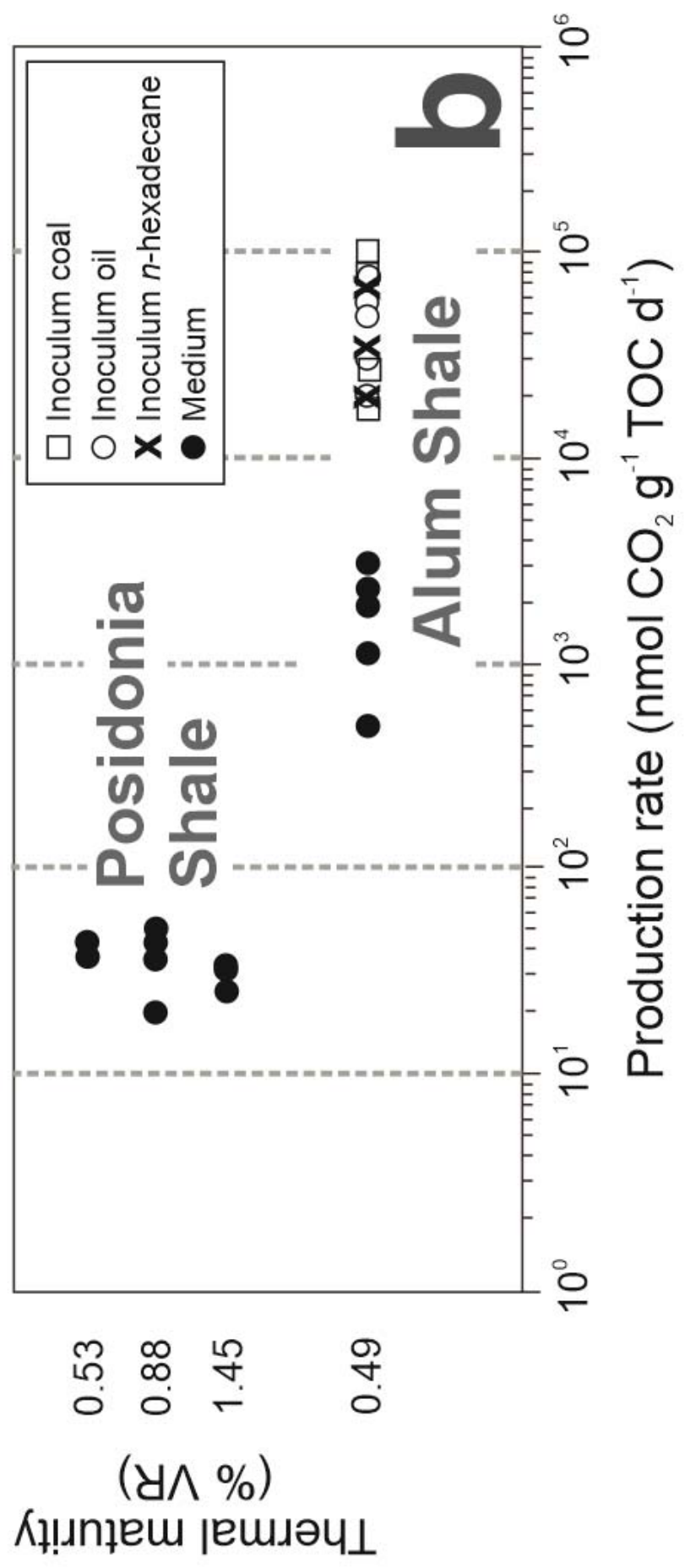




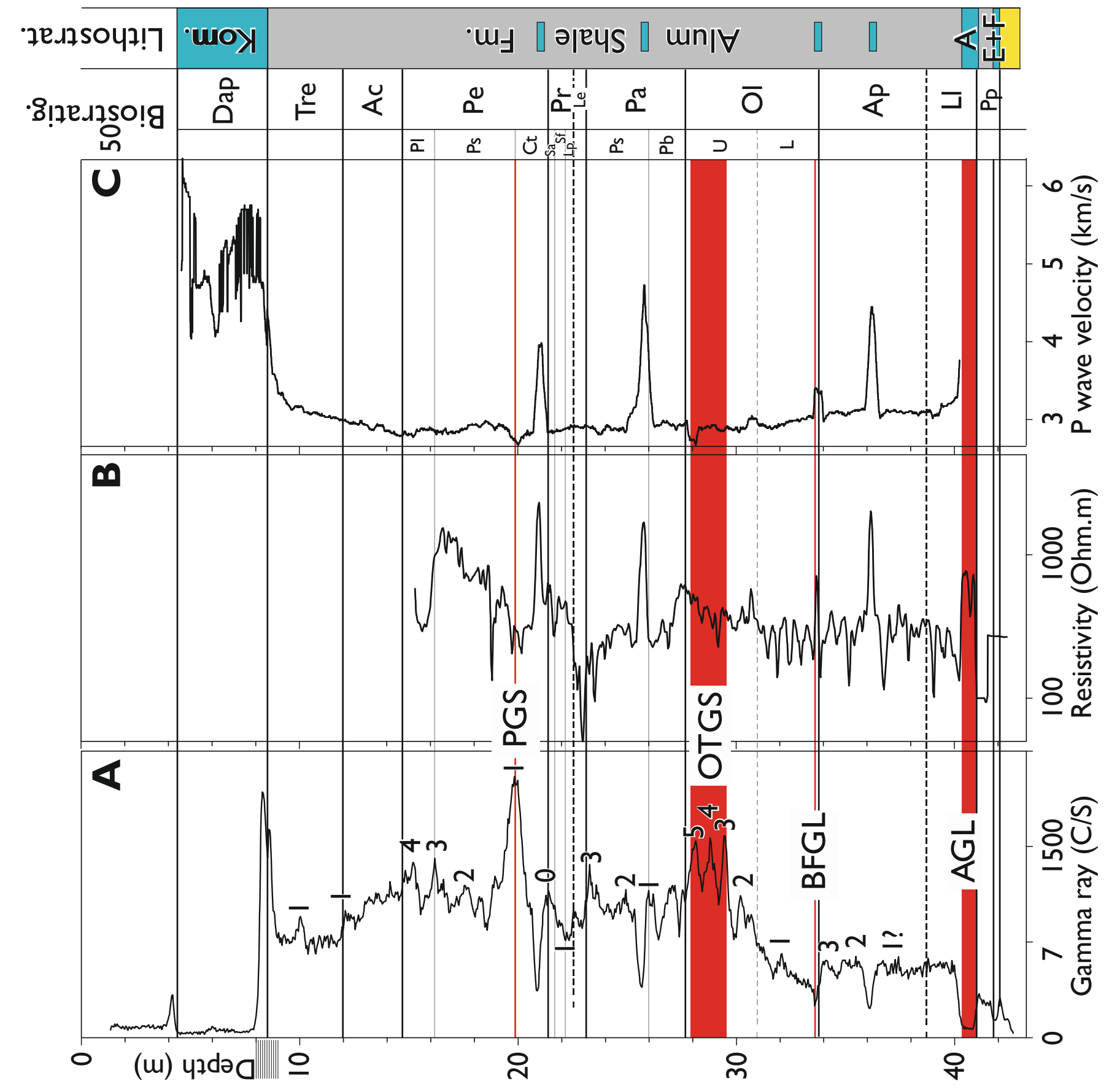



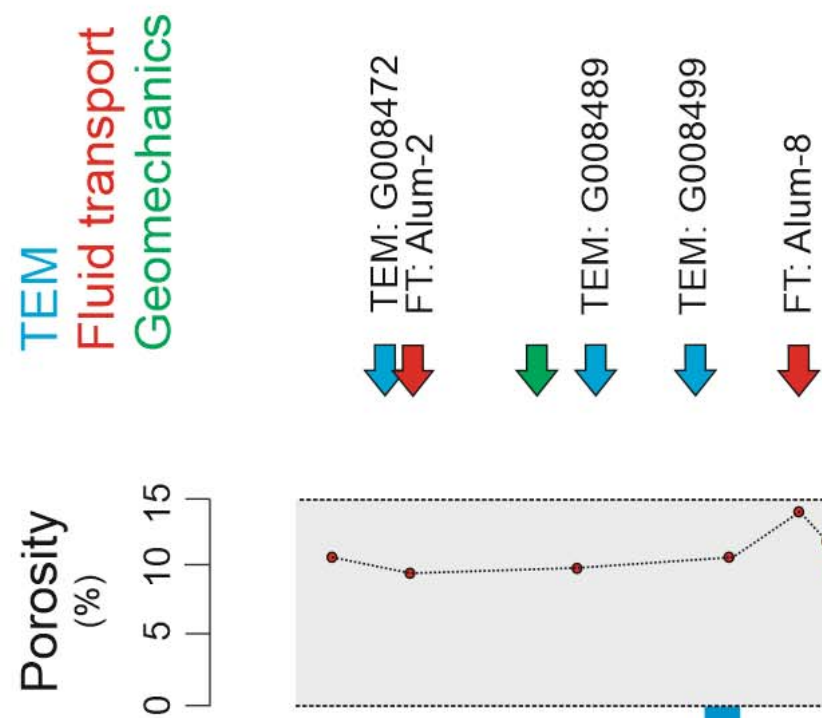

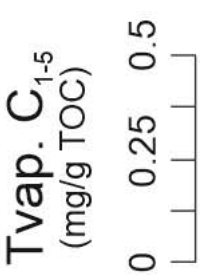

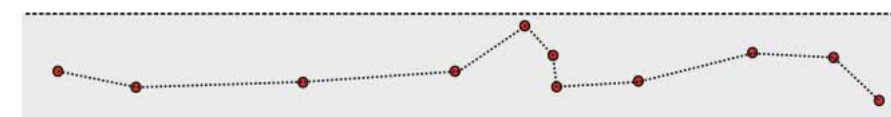

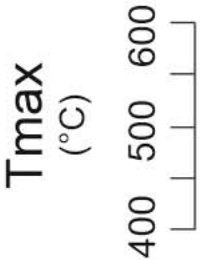

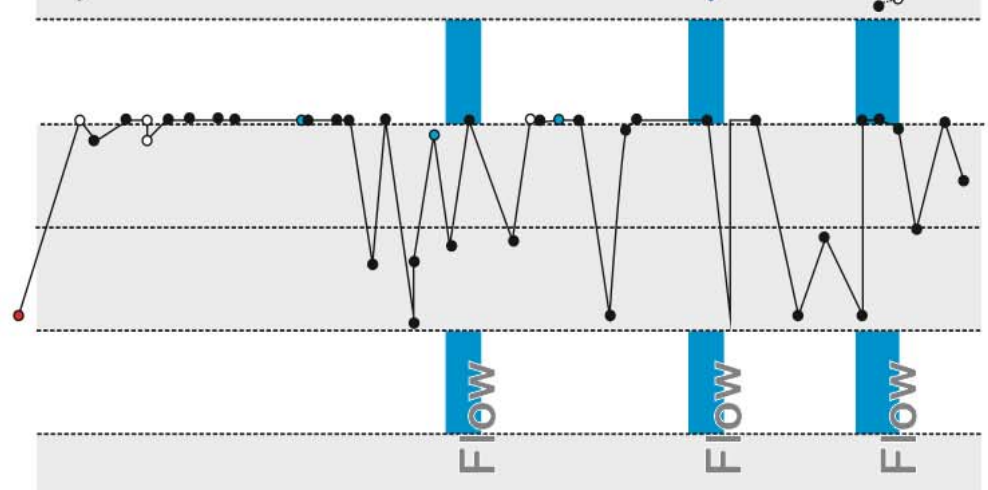

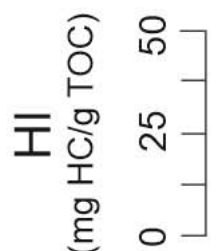
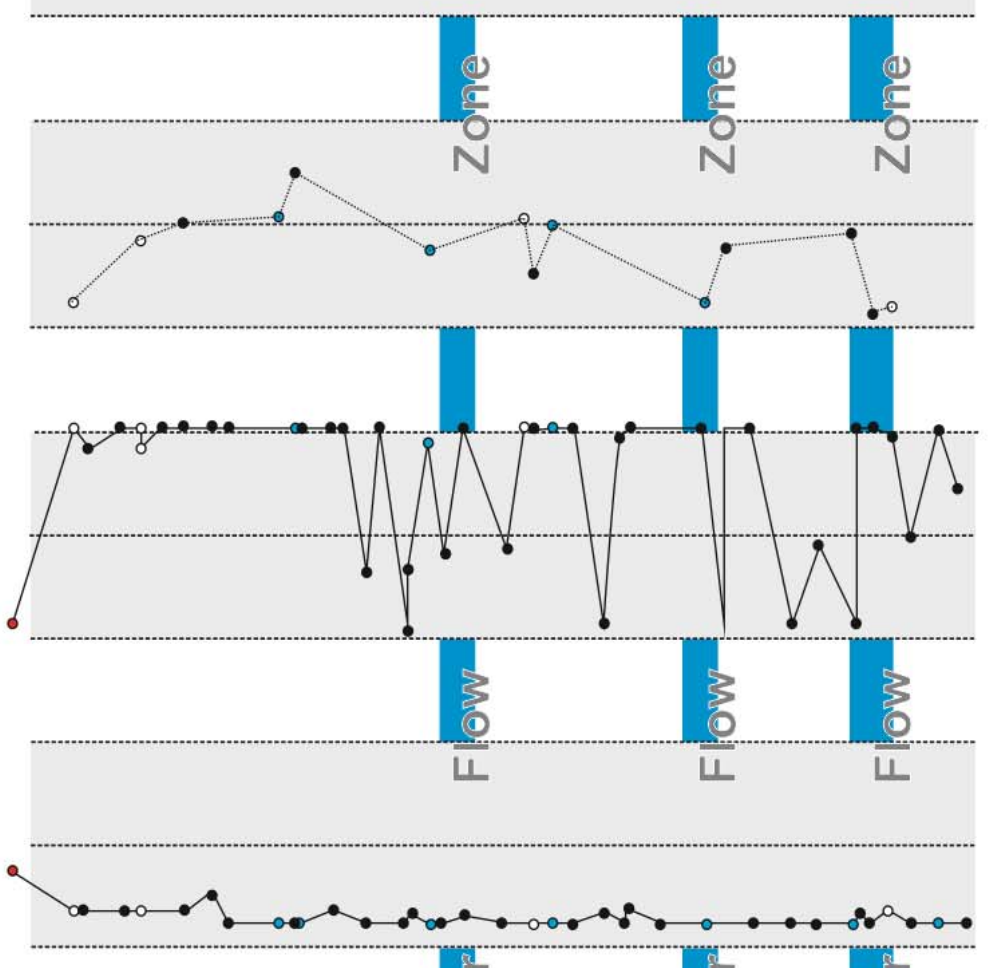

$\left.\begin{array}{ll}0 & \stackrel{6}{\circ} \\ 0 & \circ \\ 0 & 0 \\ \hdashline & 0\end{array}\right]$

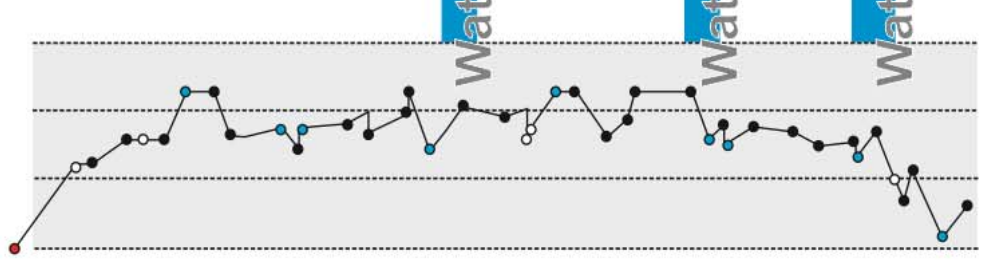

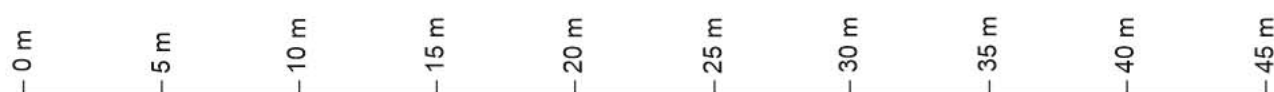

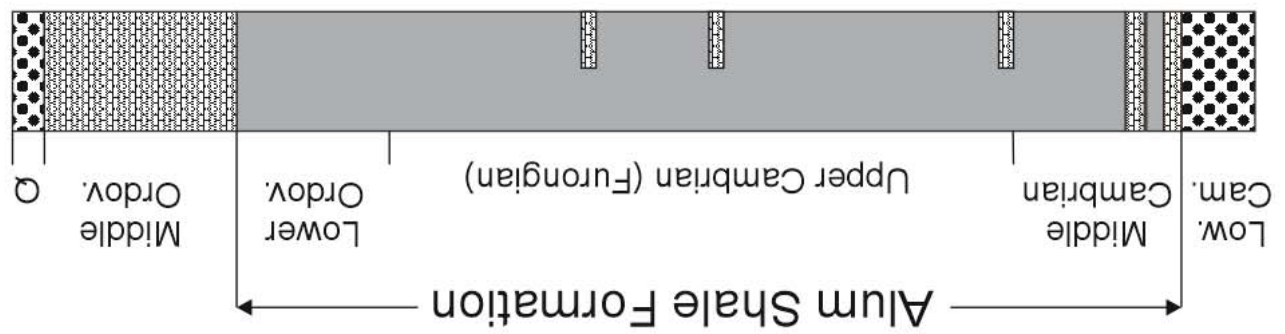




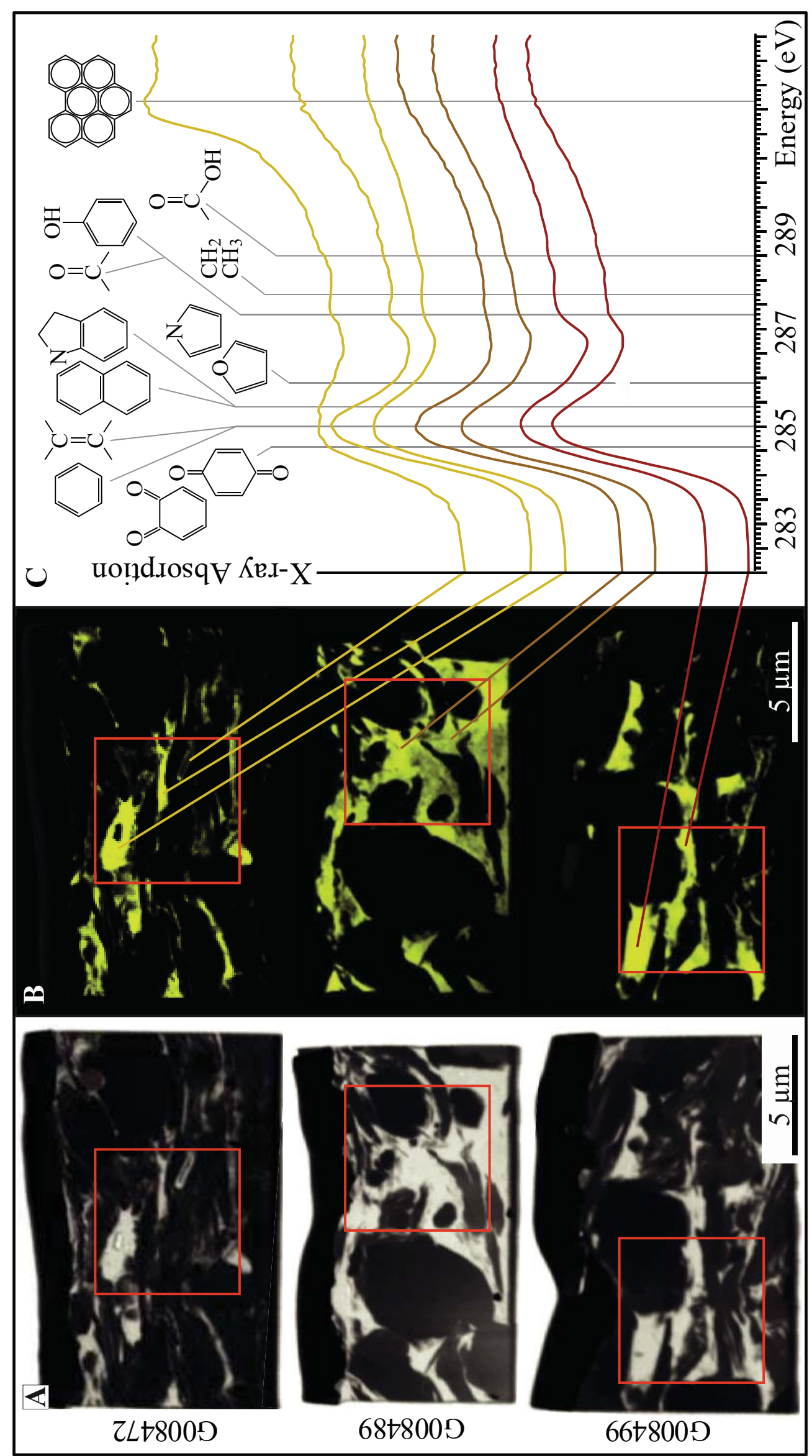

ㅁ
믐 
$\stackrel{n}{ }$
흔

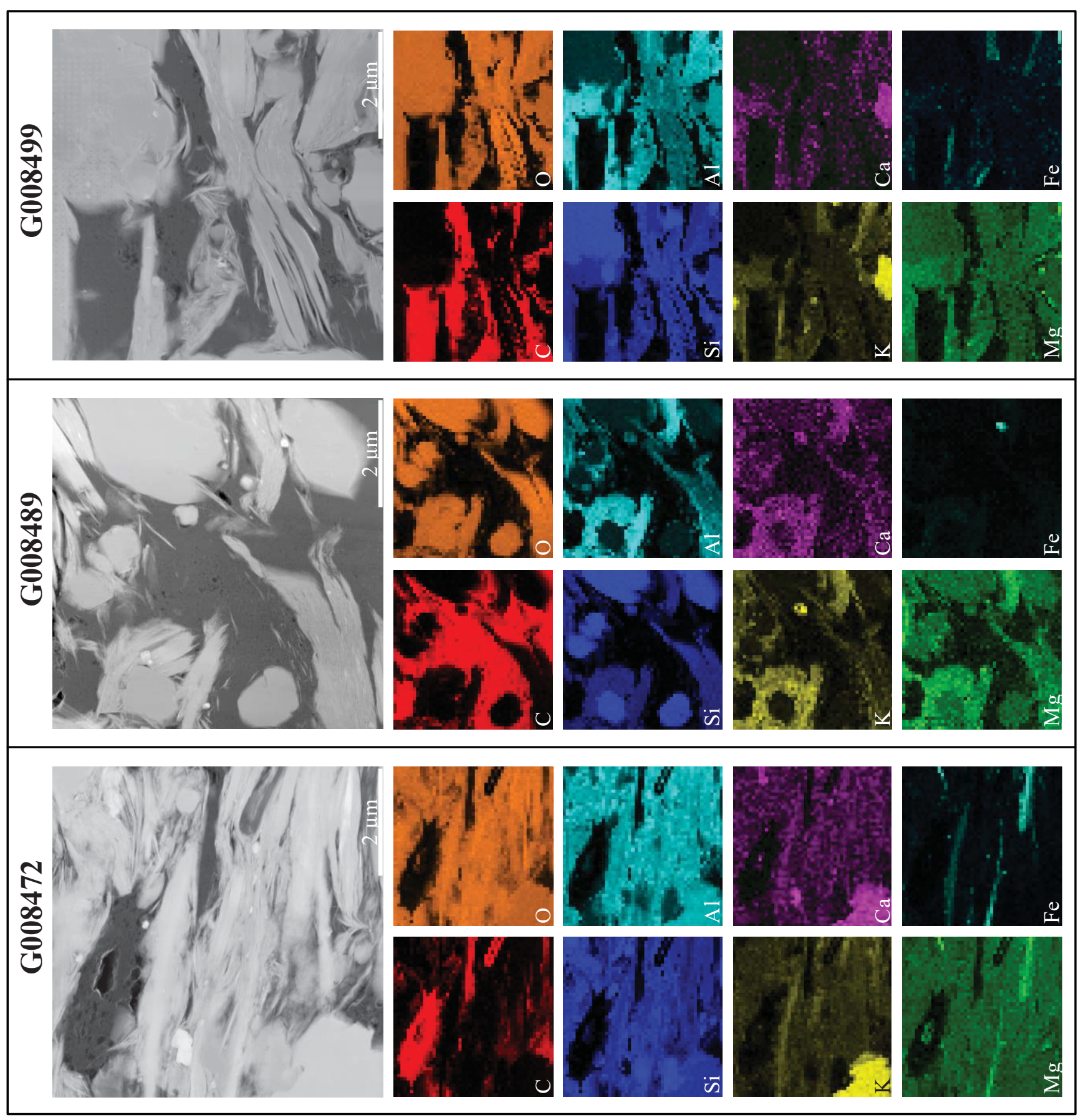




\section{$\boldsymbol{m}$}

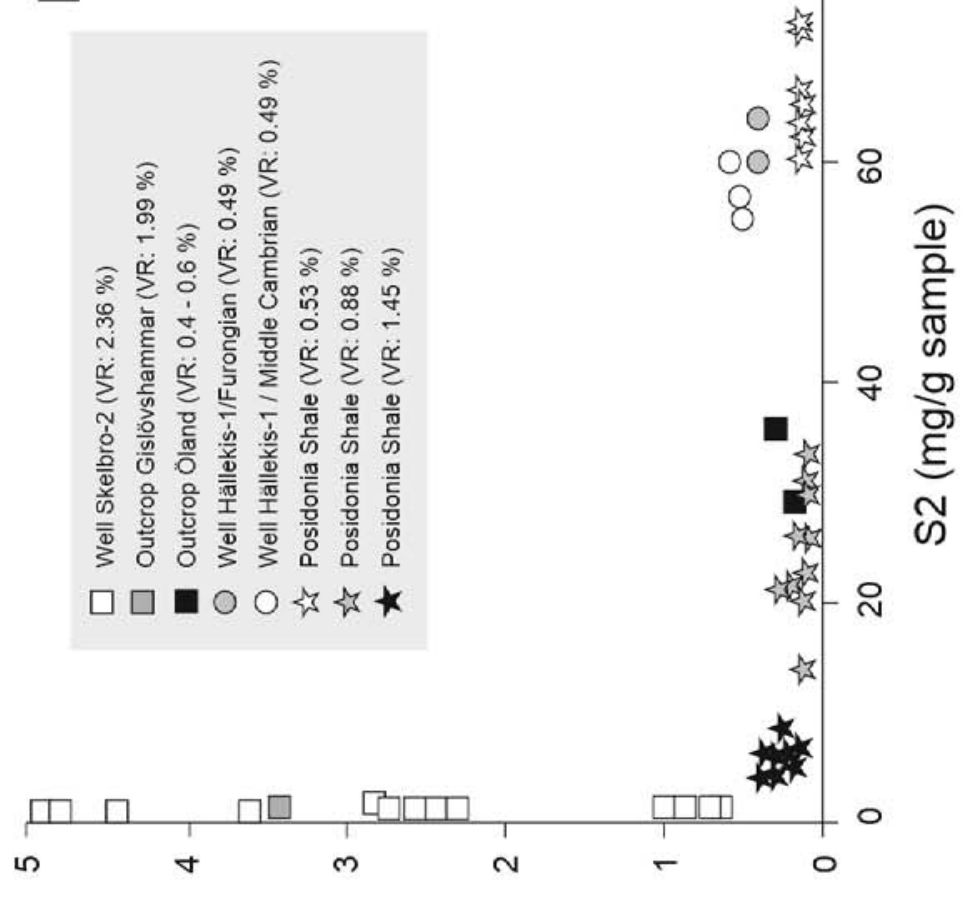

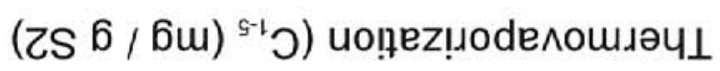

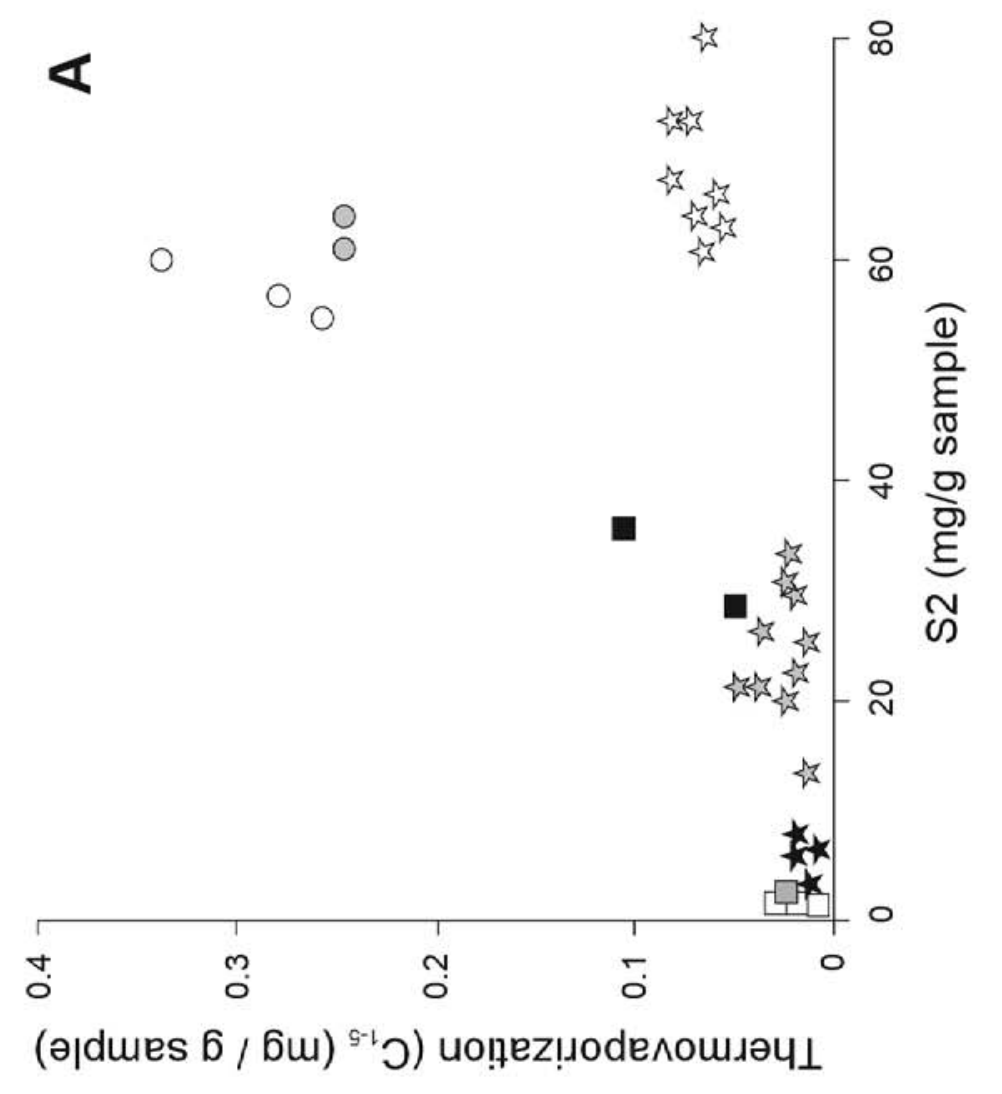




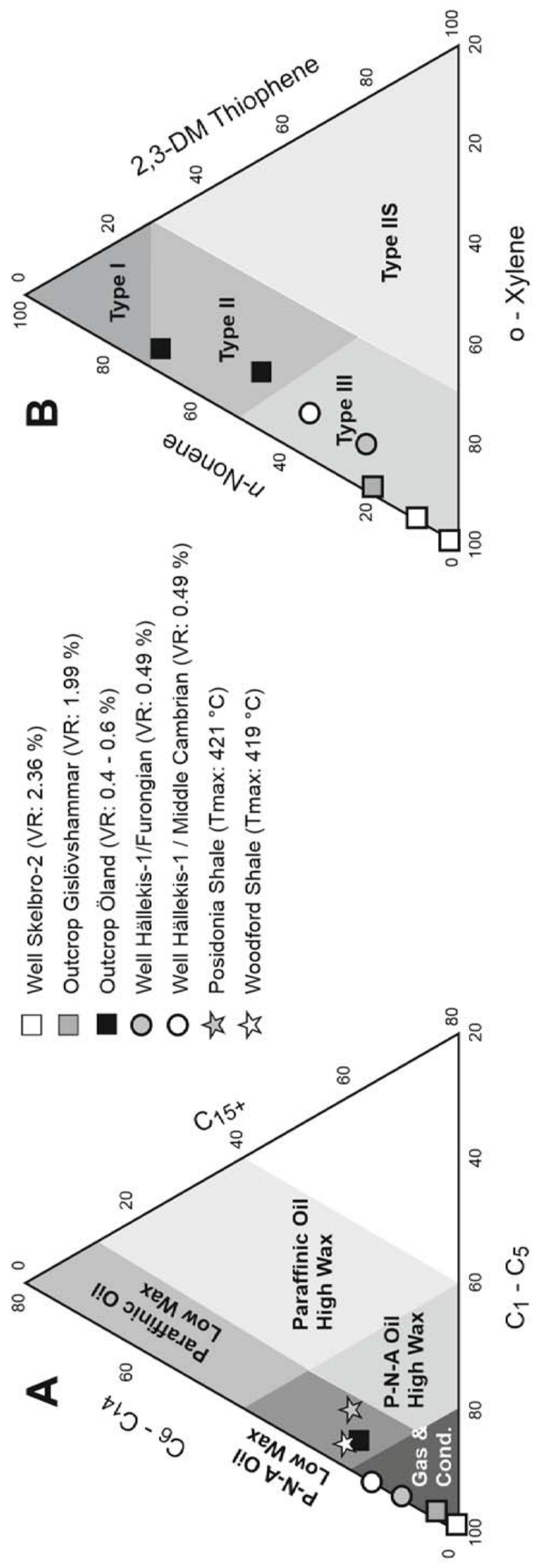

품 
ㄴำ

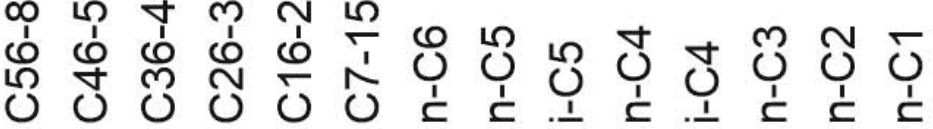

$\square \square \square \square \square \square \square \square \square \square \square \square \square \square$



ט
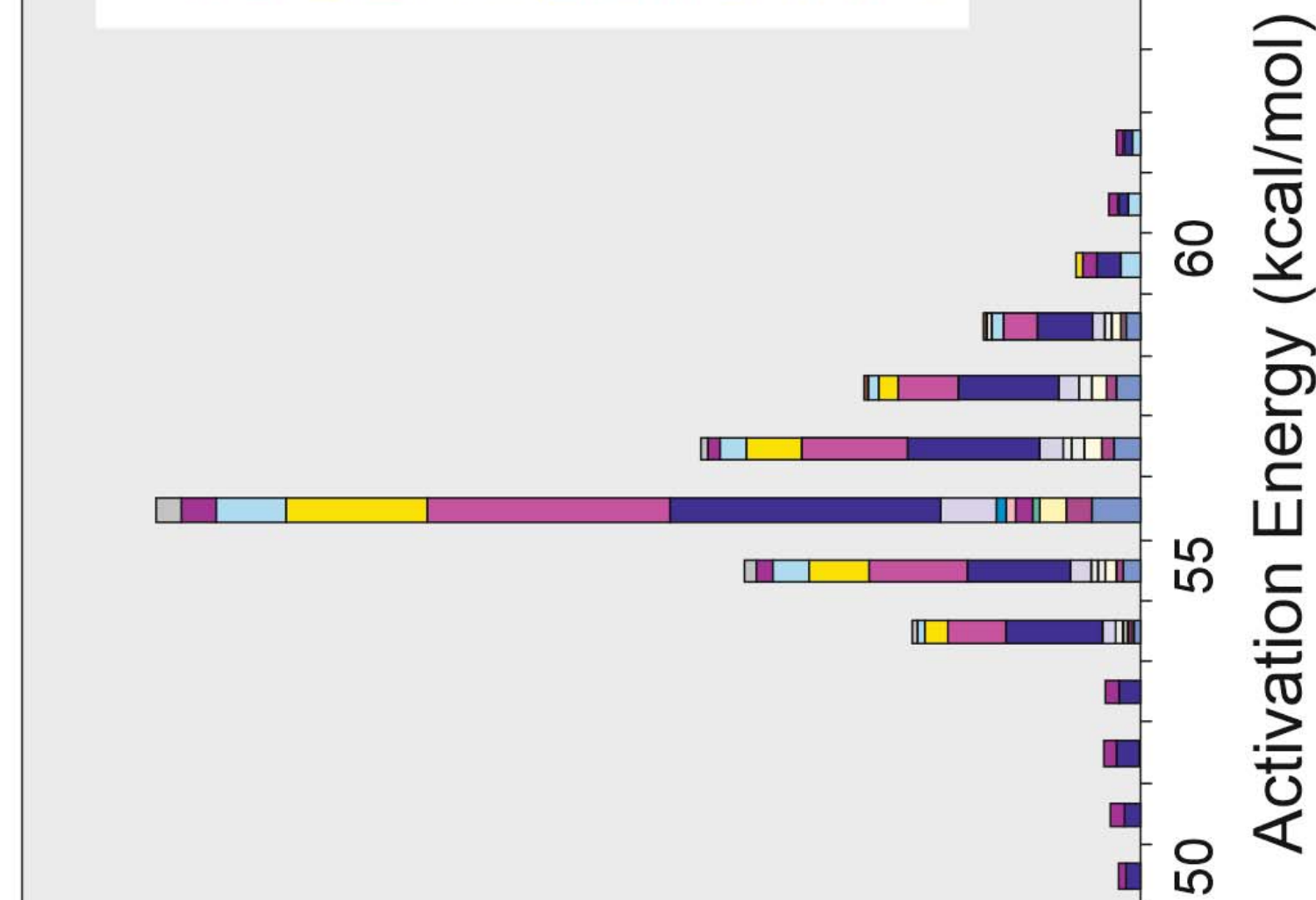

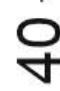

ì

i

$\stackrel{1}{\leftarrow}$

0

$\stackrel{8}{7}$

(\%) ןe!ןuәjоd 


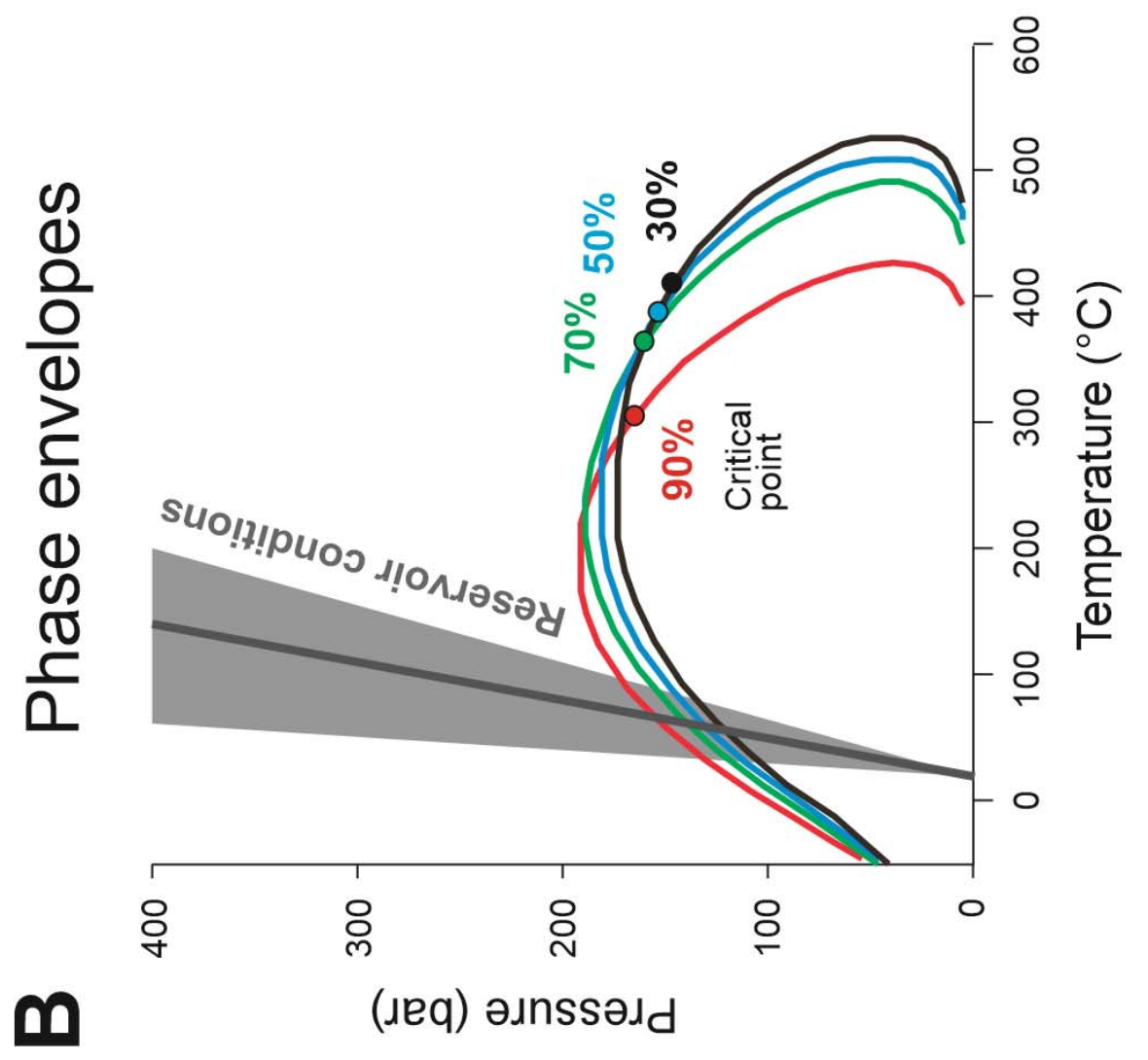

음
흠

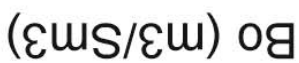

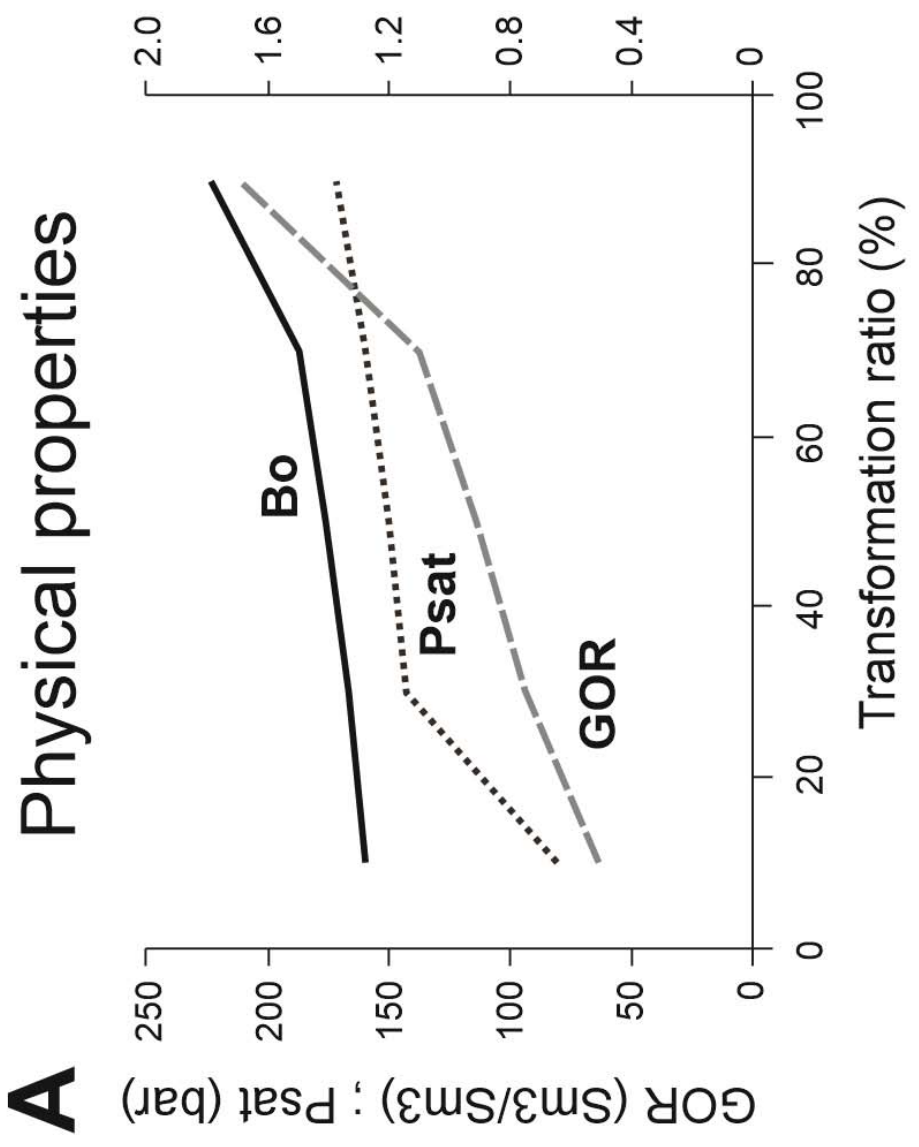




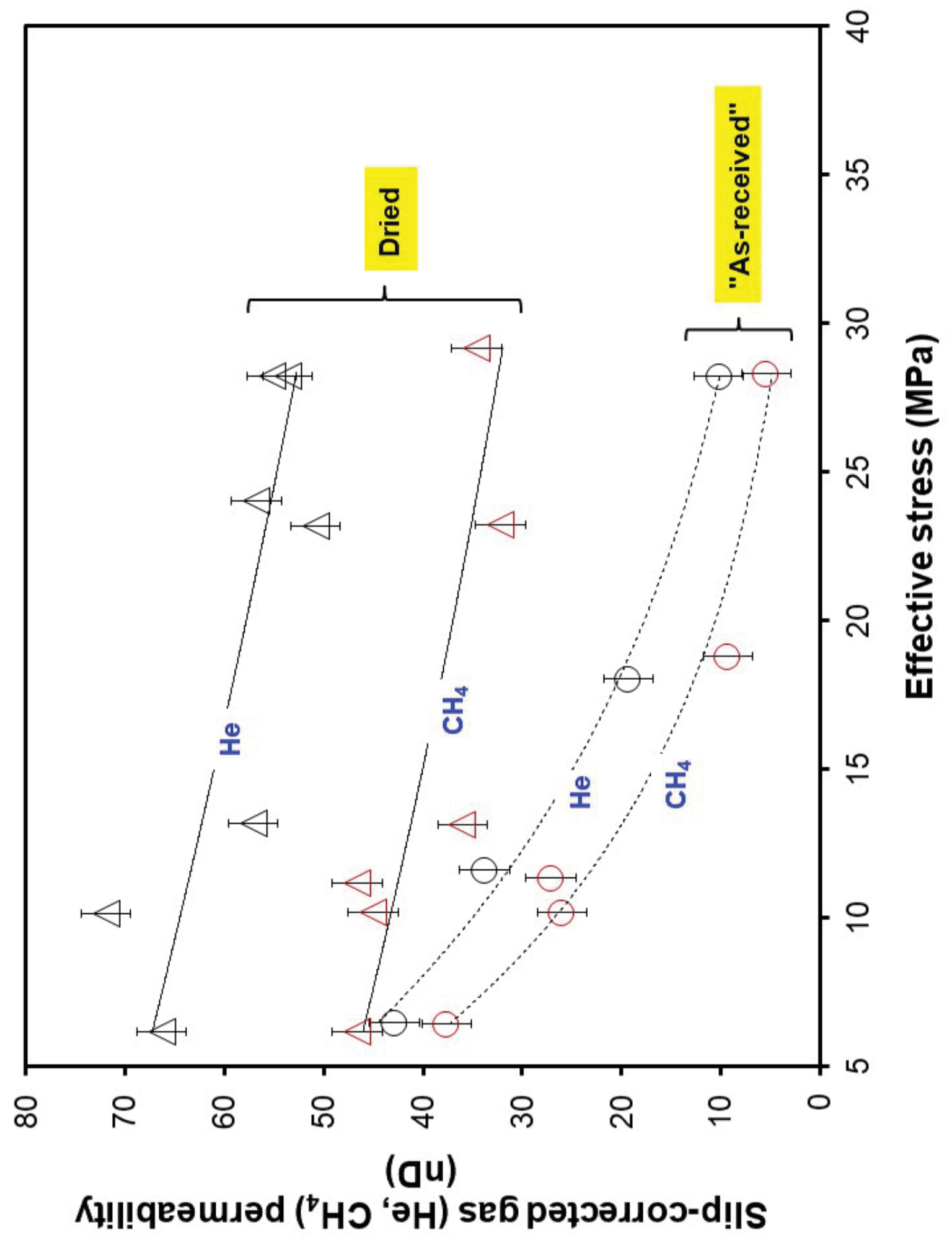




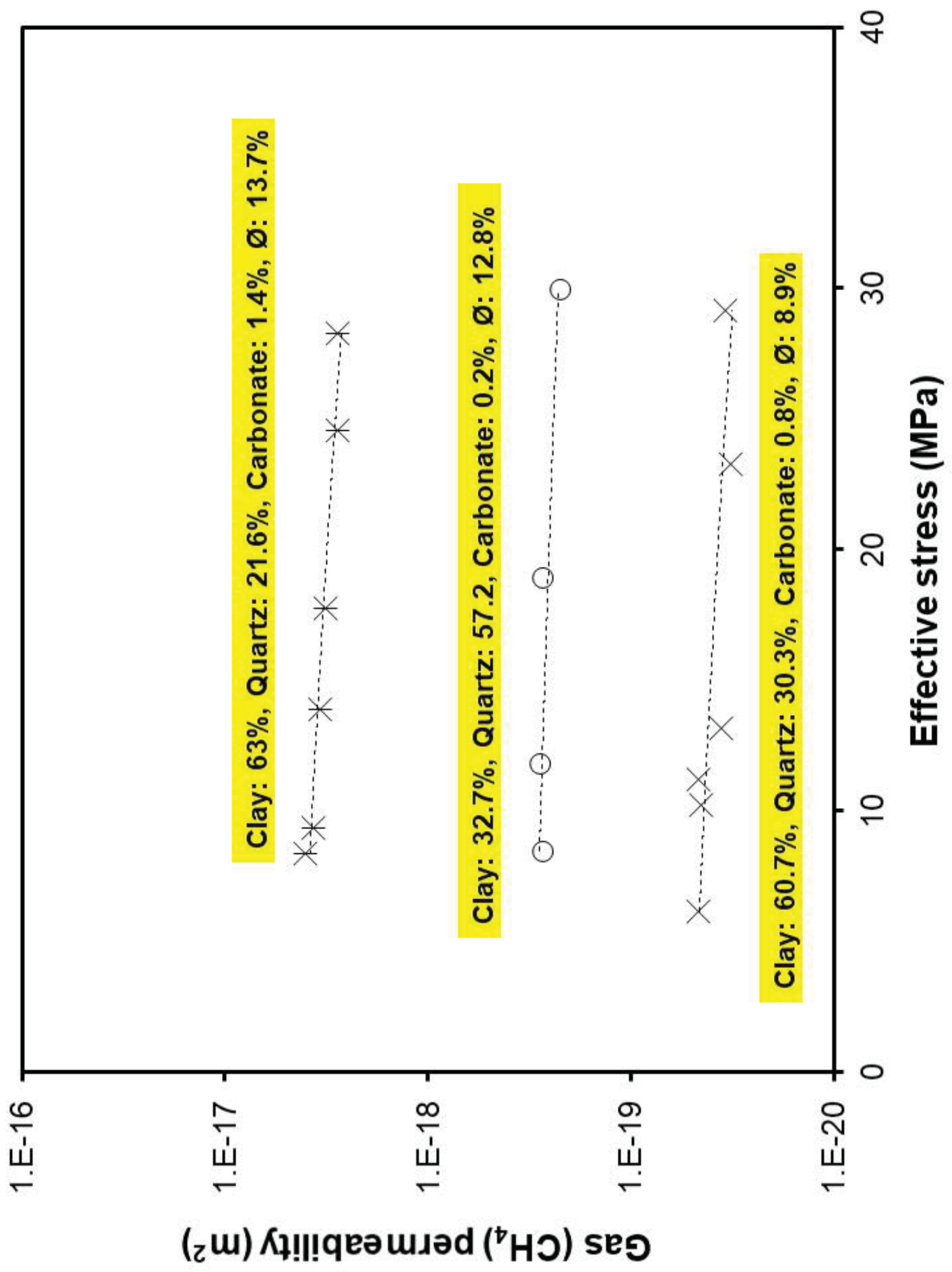




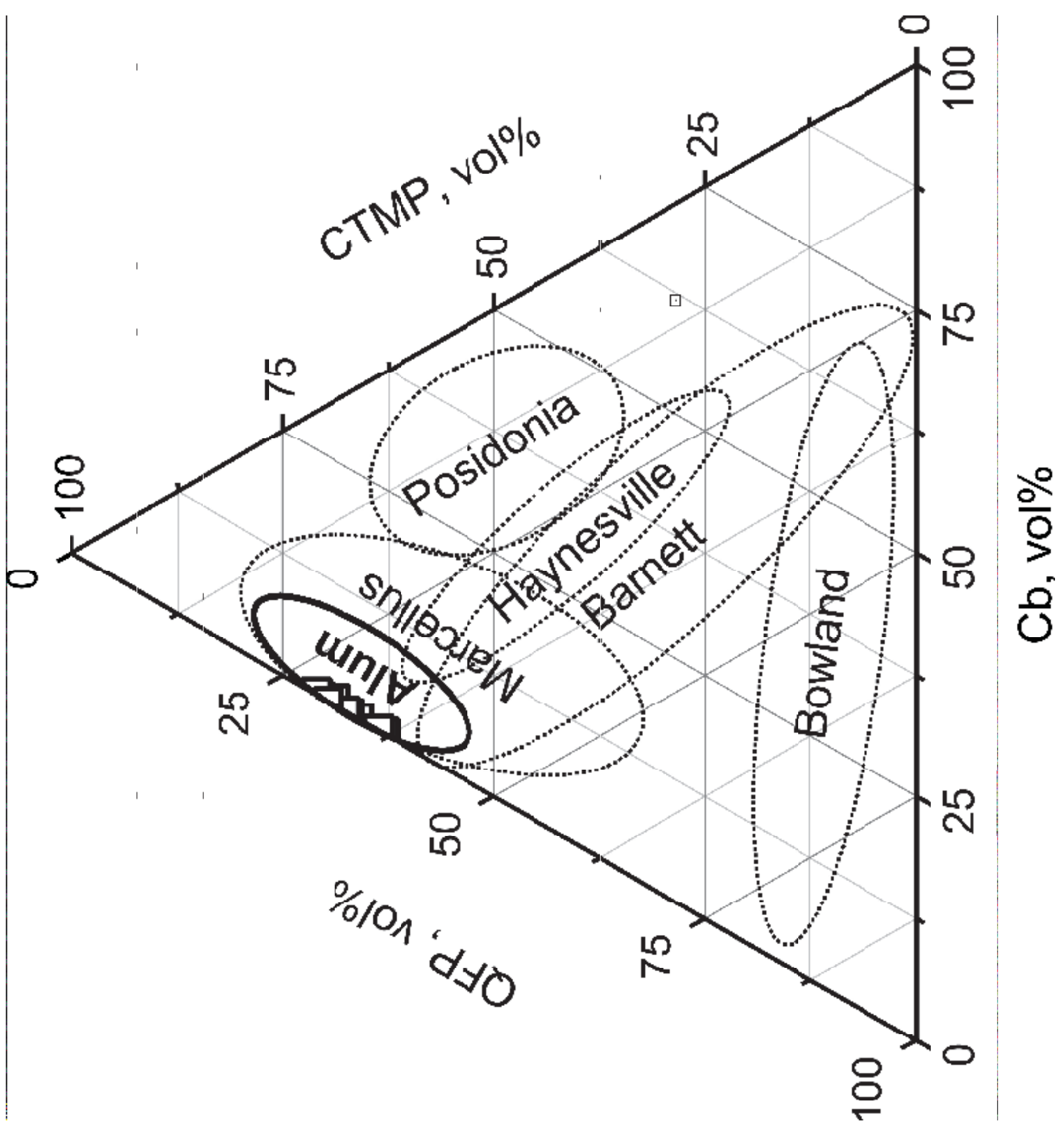




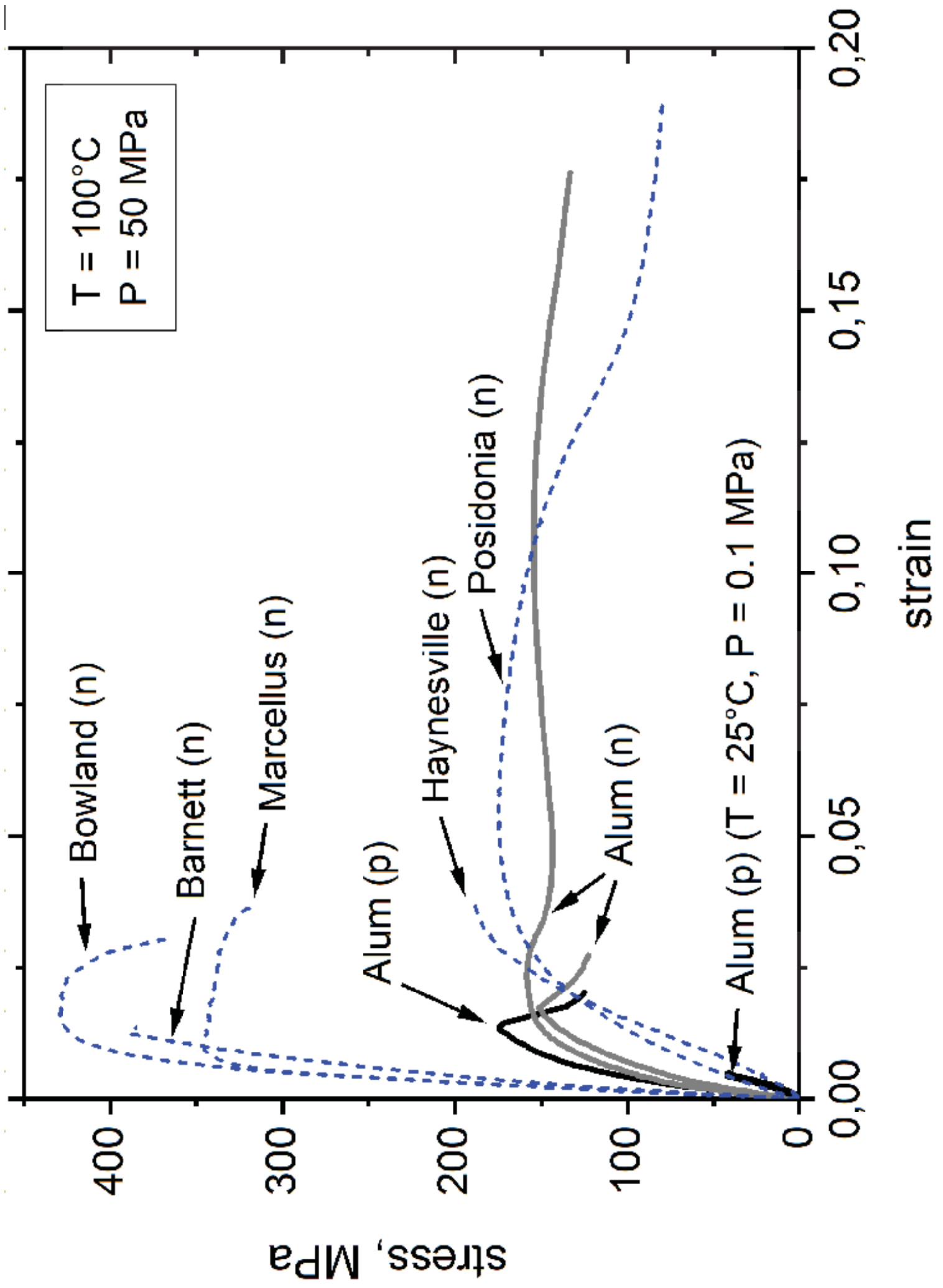




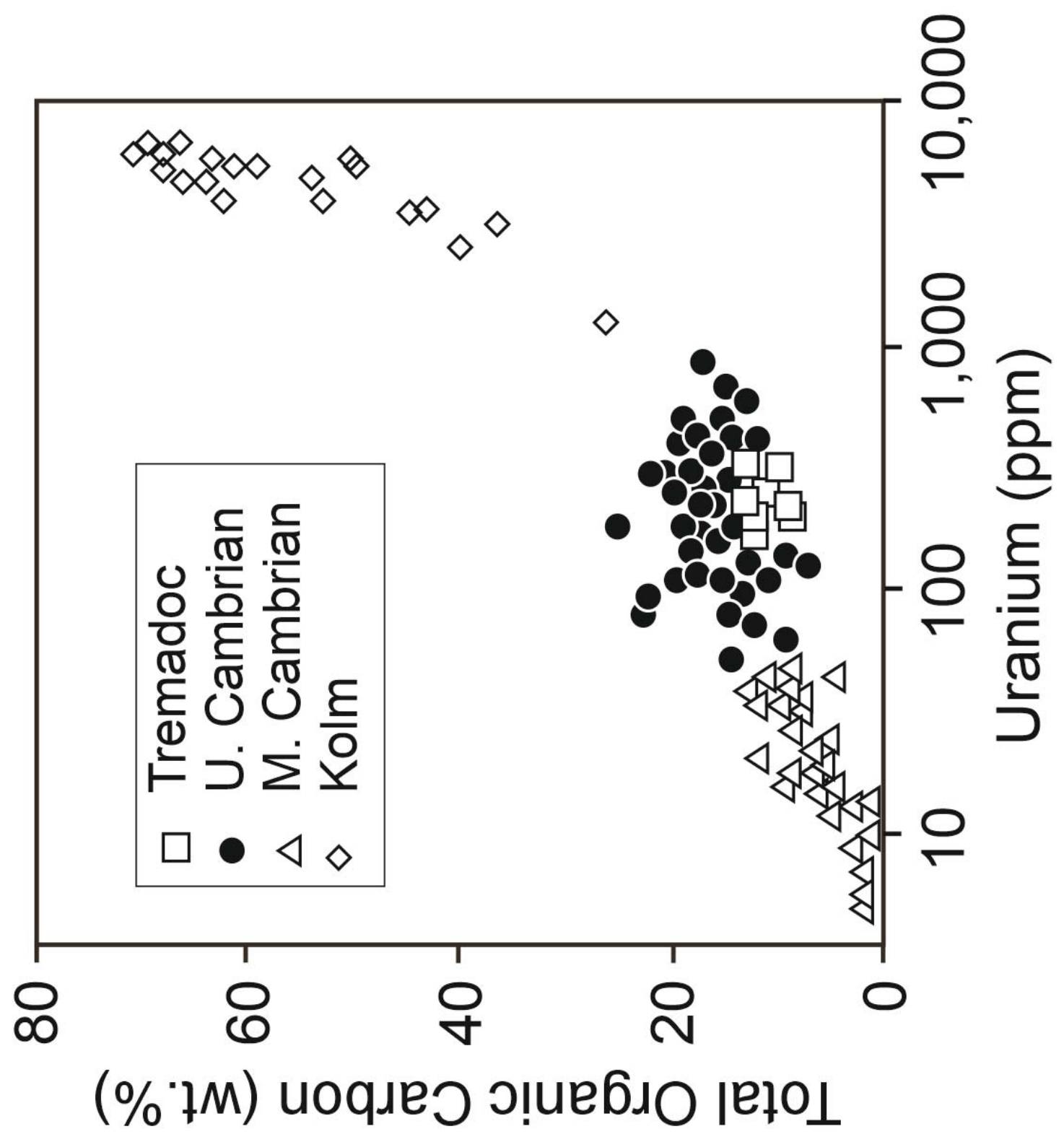




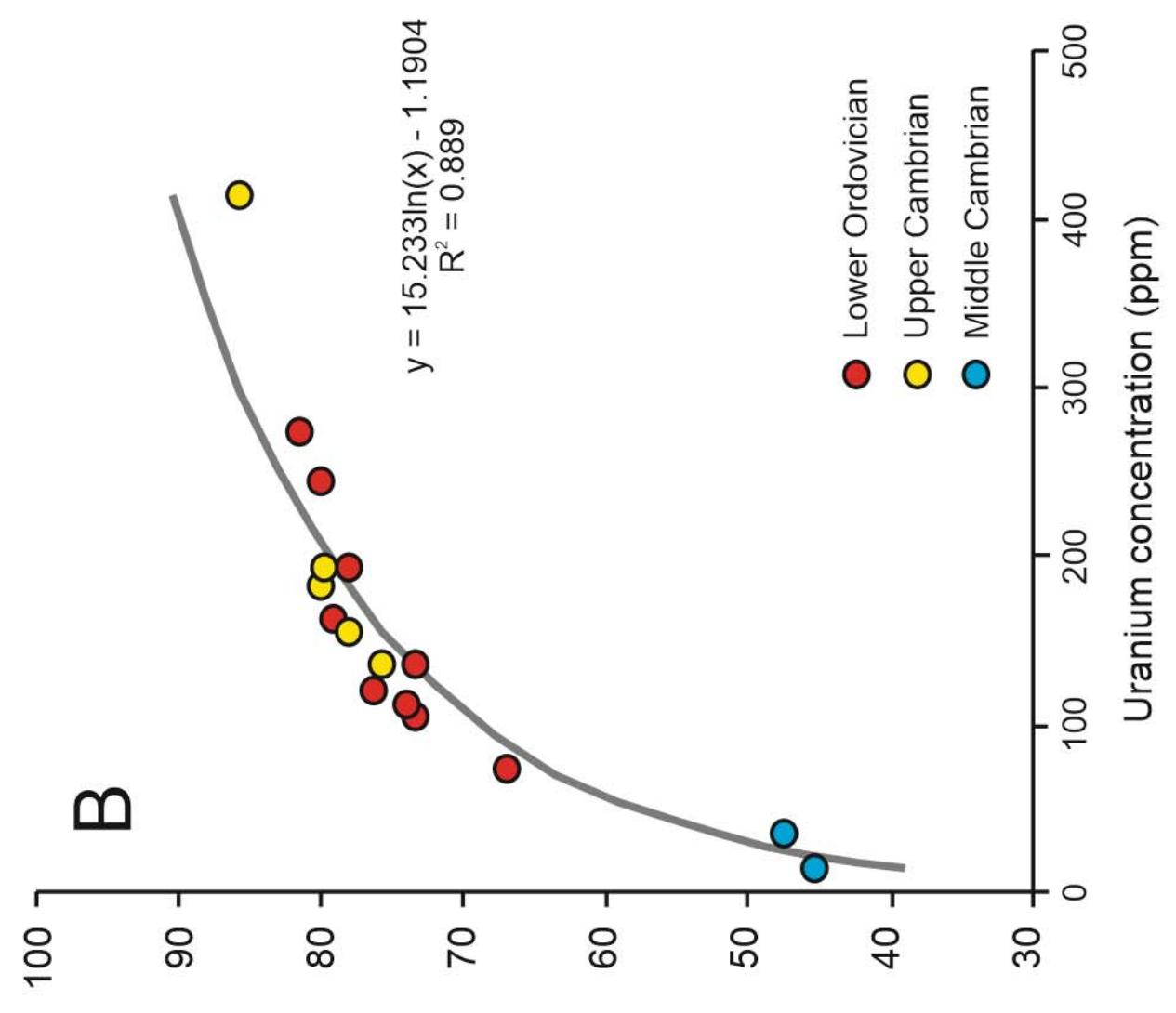

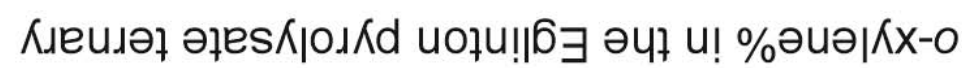

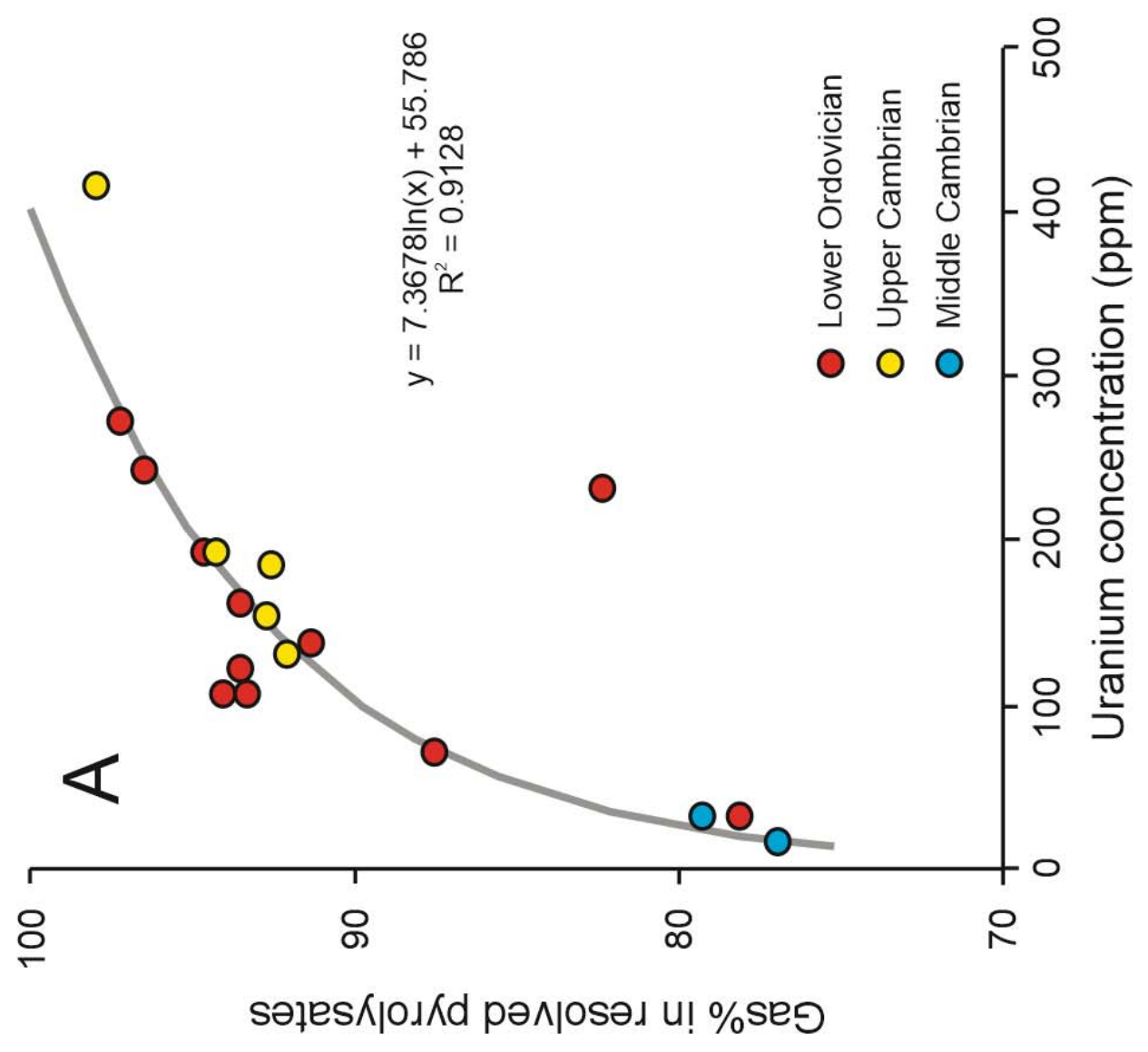


$\stackrel{\circ}{N}$

문

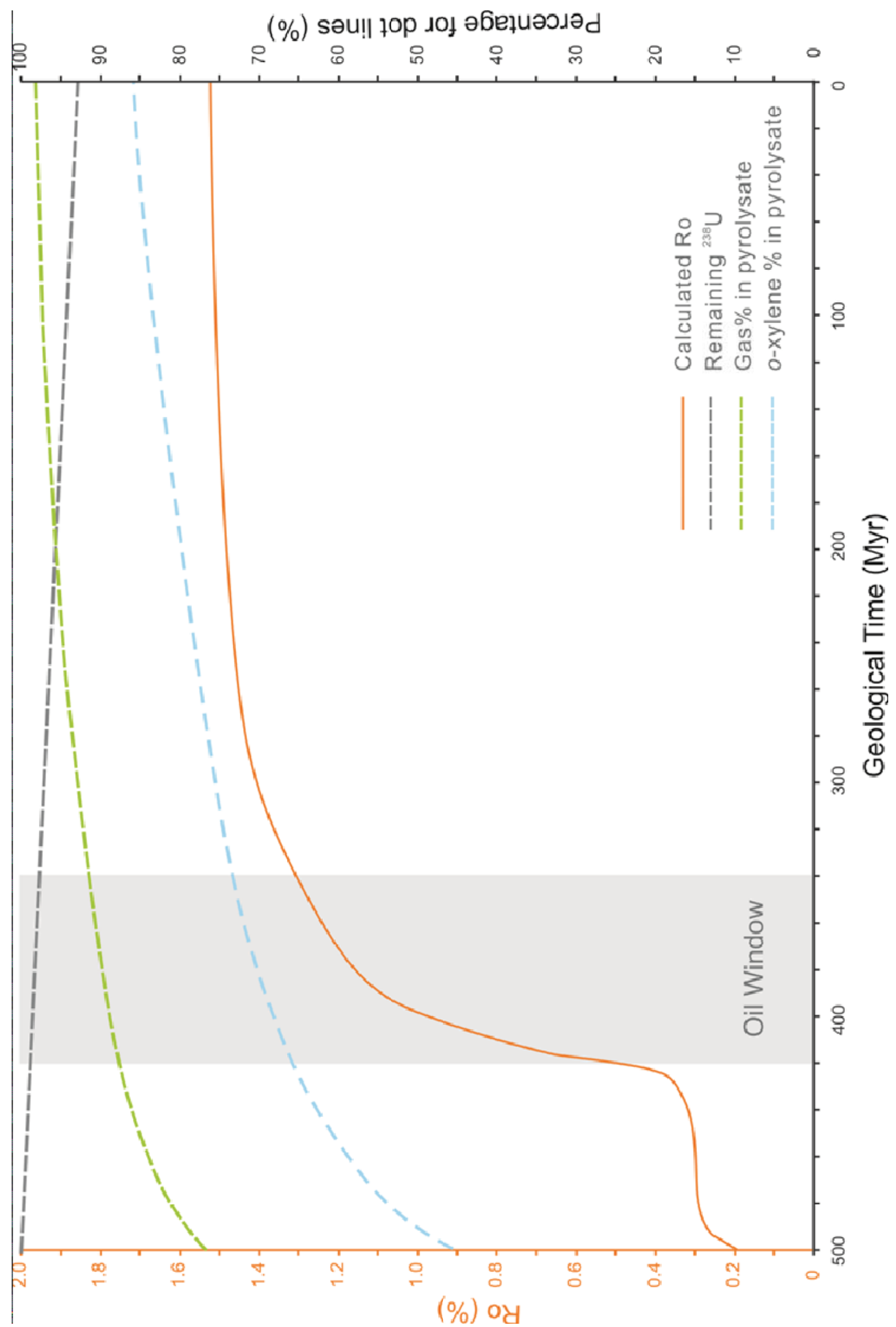

